\title{
Early Llandovery monograptids from Bornholm and the southern Urals: taxonomy and evolution
}

\author{
TATJANA KOREN’ \& MERETE BJERRESKOV
}

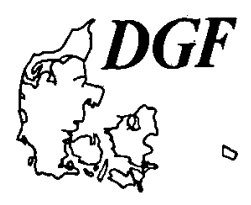

Bjerreskov, M. \& Koren', T.: Early Llandovery monograptids from Bornholm
and the southern Urals: taxonomy and evolution. Bulletin of the Geological So-
ciety of Denmark, Vol. 44, pp. 1-43. Copenhagen, 1997-03-15.
https://doi.org/10.37570/bgsd-1998-44-01

\begin{abstract}
The most complete Lower Llandovery succession of mudrocks yielding graptolites within the ascensus, acuminatus and vesiculosus Biozones was studied in the Billegrav-1 core, South Bornholm. Special attention is given to the taxonomy and stratigraphical ranges of monograptids found in the vesiculosus Biozone in the core and nearby exposures in Øle $\AA$. Monograptids of the ascensus-acuminatus and vesiculosus Biozones were also discovered in condensed carbonaceous shale sequences of the Sakmara Formation in the southern Urals. Monograptids from Bomholm and the southern Urals are described, and referred to 5 genera and 17 species (4 new and 4 in open nomenclature). The new genus Huttagraptus (type

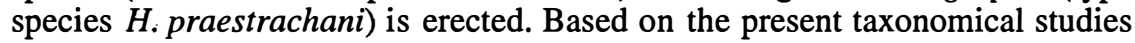
the main morphological trends, phylogenetical relationships and diversity dynamics of the earliest monograptids are discussed.
\end{abstract}

Keywords: Graptoloids, monograptids, Early Silurian, taxonomy, biostratigraphy, evolution, phylogeny, Bornholm, Denmark, southern Urals, Russia.

T. Koren', All-Russian Geological Research Institute (VSEGEI), 199026 St. Petersburg, Sredny 74, Russia. M. Bjerreskov, Geological Museum, Øster Voldgade 5-7, DK-1350 Copenhagen K, Denmark. 16 August 1996.

The lack of detailed knowledge of the taxonomy, stratigraphical ranges and phylogenetic relationships of the earliest Llandovery monograptids results from a global rarity of well preserved specimens from the acuminatus and vesiculosus Biozones. The monograptids have been most extensively studied in the British sections (Hutt 1968, 1974, 1974-1975; Hutt \& Rickards 1970; Hutt et al. 1970; Rickards 1974, 1976; Rickards \& Hutt 1970; Rickards \& Rushton 1968; Rickards et al. 1977). More recently they have been found and partly described from Bohemia (Štorch 1986, 1988, 1994), Canadian Arctic Islands (Melchin 1989; Lukasik \& Melchin 1994) and China (Chen 1984, 1986; Chen \& Lin 1978; Fang et al. 1990; Li et al. 1990).

A project to examine the earliest monograptids from Bornholm, Denmark and the southern Urals, Kazakhstan was initiated in 1993, the main goal of which was a comparative analysis of their taxonomic composition and morphology in different sedimentary environments. Some of the early Llandovery monograptids from the Øle §̊ locality, South Bornholm had previously been described by Bjerreskov (1975). Early Llandovery monograptids had been collected from the southern Urals since the early 1950 s to mid 1970 s, but no taxonomical studies had been undertaken. The present paper analyses the taxonomy, morphology and diversity dynamics of monograptids, in the early Llandovery acuminatus and vesiculosus Biozones in both regions.

\section{Geological setting and depositional environments}

Bomholm is located within the Sorgenfrei-Tornquist Zone (sensu EUGENO-S working group 1988; Vejbæk et al. 1994), which forms the boundary between the relatively stable Fennoscandian/East European Platform to the northeast and the northwest European sedimentary basins to the southwest. The Llandovery and Wenlock graptolite-bearing mudstones, approximately $110 \mathrm{~m}$ thick, are exposed in the rivulet Øle $\AA$, South 

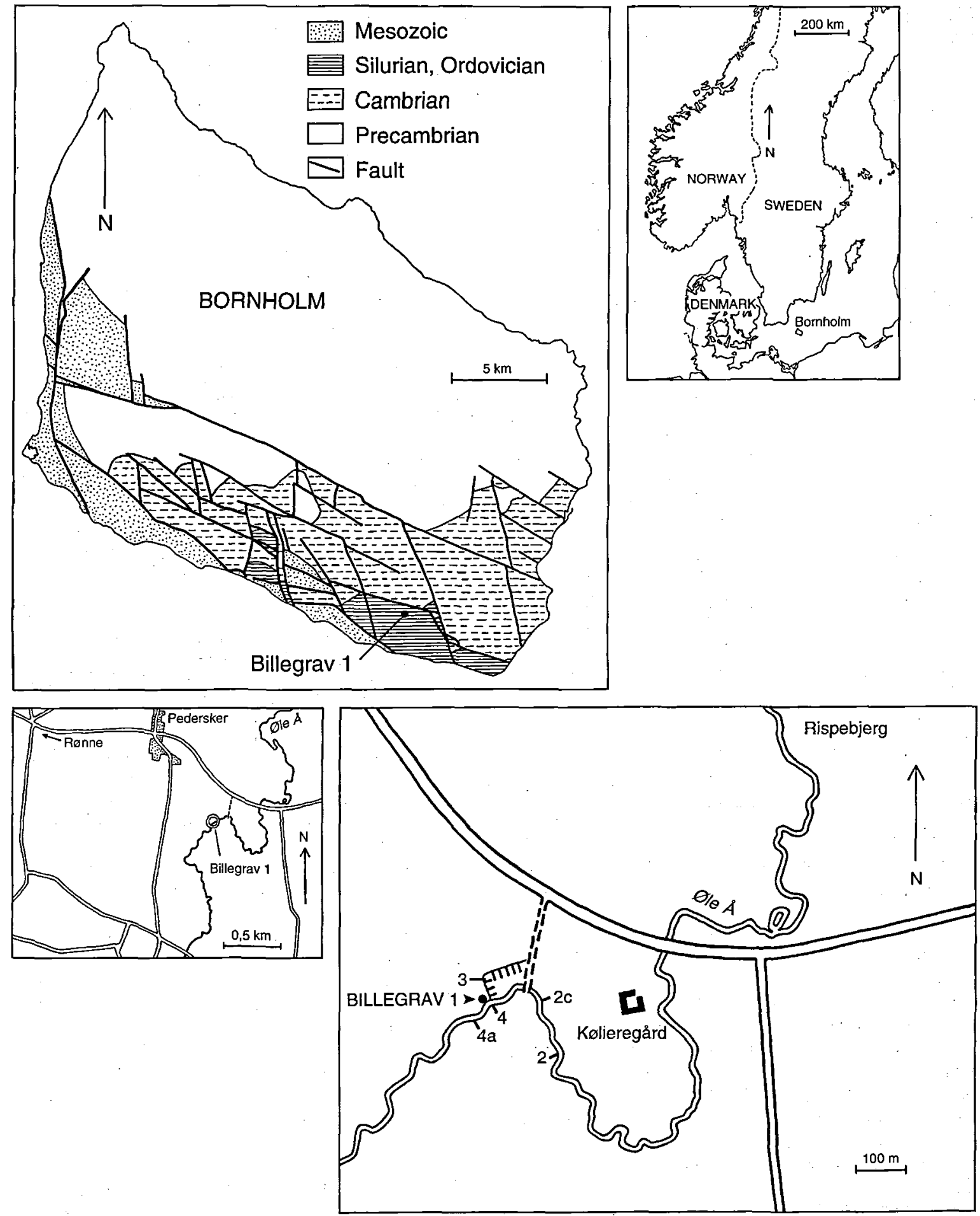

Fig. 1. Schematic geographical map showing the graptolite localities and Billegrav-1 core in South Bornholm, modified after Bjerreskov (1975) and Pedersen (1989). 


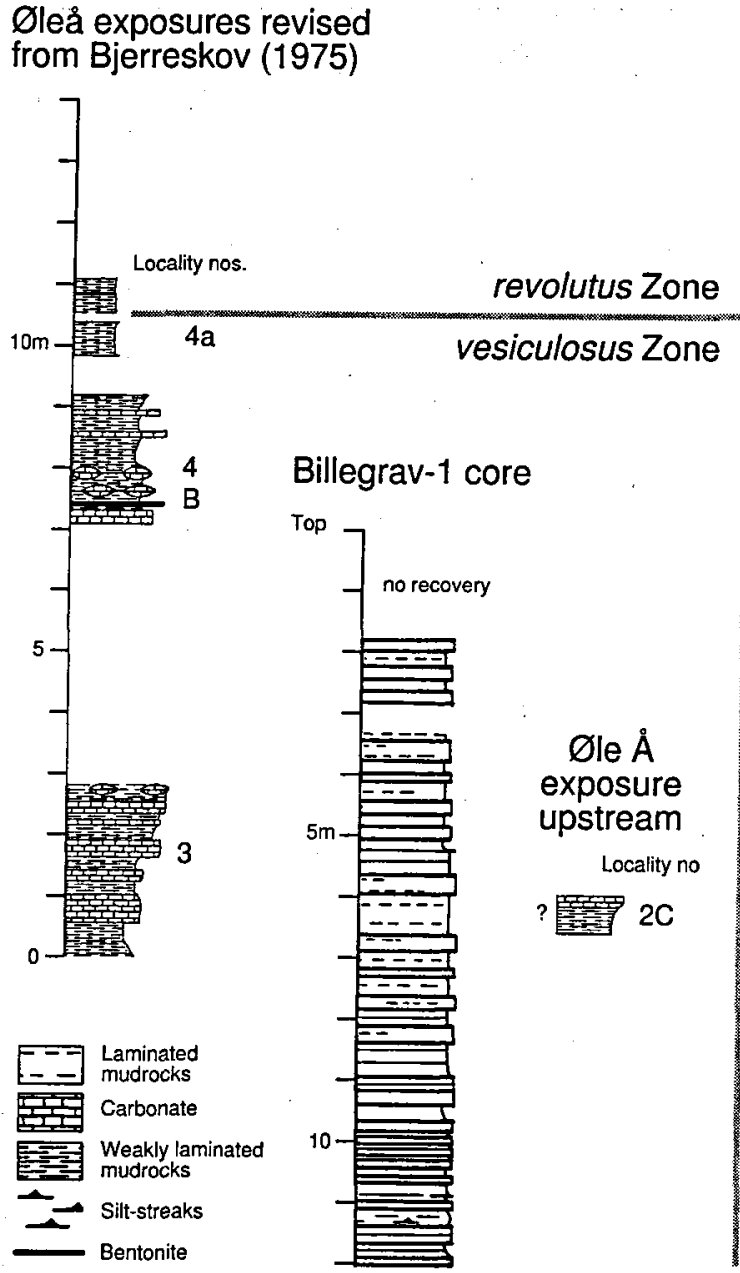

Fig. 2. Stratigraphical position of the Øle $\AA$ localities (partly after Bjerreskov 1975) and the upper part of the Billegrav1 core sequence (after Pedersen 1989).

Bornholm (Fig. 1). They occur in a number of small fault blocks tilted at low angles and are only accessible along small streams (Bjerreskov \& Stouge 1985).

For the present study new well preserved graptolites of the vesiculosus Biozone (= acinaces Biozone, Bjerreskov 1975) have been collected from the bottom of the rivulet from the exposures $4 \mathrm{a}$ and $2 \mathrm{c}$ (Figs 1,2). The well-preserved pyritized graptolites (exp. 4a) occur in finely laminated light grey to dark grey siltshales. The dark grey laminated mudstones (exp. 2c) yield numerous flattened specimens. However, in all localities studied the lowermost Silurian strata below the vesiculosus Biozone are not exposed.

The complete sequence of stratigraphically well dated graptolite assemblages of the persculptus, ascensus, acuminatus and vesiculosus Biozones was discovered in the shallow drill-hole Billegrav-1 in the valley of Øle $\AA$ close to exposure 4 (Fig. 1). System- atic search for graptolites in the core material resulted in a very comprehensive graptolite collection.

The Bornholm graptolite-bearing mudrocks were formed in the outer part of the epicontinental sea covering a comparatively stable Baltoscandian platform which was situated in subtropical to moderately low palaeolatitudes in Late Ordovician to Early Silurian time. A depositional model for the Lower Palaeozoic mudshales, alternating with greyish mudstones and silt-streaked shales was discussed in detail by Pedersen (1989), based on the core material from Billegrav-1. They were interpreted as being deposited below the wave base in a low energy, anoxic environment with short periods of better ventilation and higher energy hydrodynamics. The average or background sedimentation was represented by the black and dark grey laminated and organic rich mudshales and siltshales yielding numerous graptolites. The sediments were not significantly bioturbated, suggesting that habitability by benthic faunas was very restricted.

The deposition may have been rapid by comparison with the Ordovician strata (Lindström 1971) and sediments may have been deposited below the wave base. An average rate of deposition could be about $1 \mathrm{~mm}$ per 10 years (Pedersen 1995, personal communication). Pale silty laminae sometimes show graded bedding which may be a sign of rapid settling from suspension and represent short duration events resulting in formation of very distal turbidite or storm layers.

The second region of this study is the Mugodzhary Range within the Kazakhstan part of the southern Urals (Fig. 3). The graptolite-bearing strata are represented here by the condensed sequence of carbonaceous, silicified shales and cherts of the Sakmara Formation. Continuous sequences within the Sakmara Formation are rarely preserved in extensive stratigraphical ex-

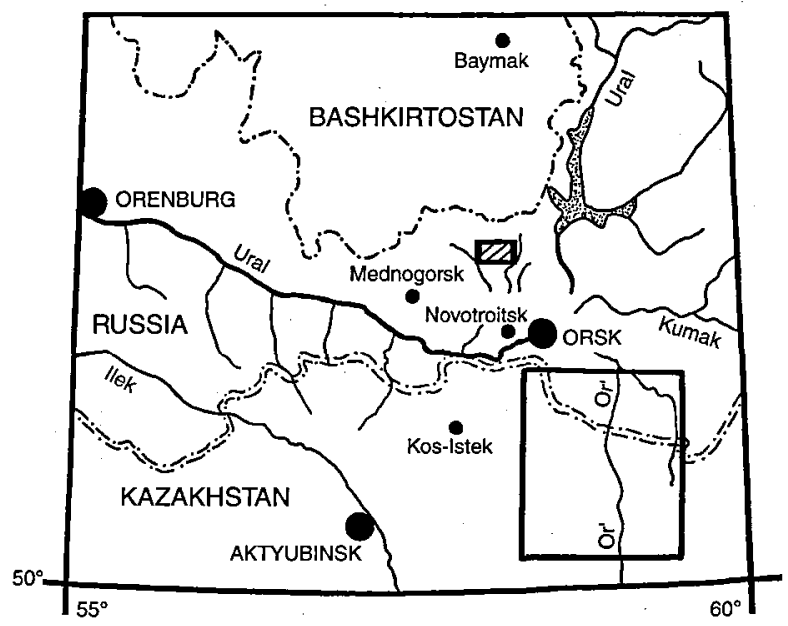

Fig. 3. Schematic geographical map showing the Kos-Istek Region of the southern Urals, Western Kazakhstan (from Koren' \& Rickards 1996). 


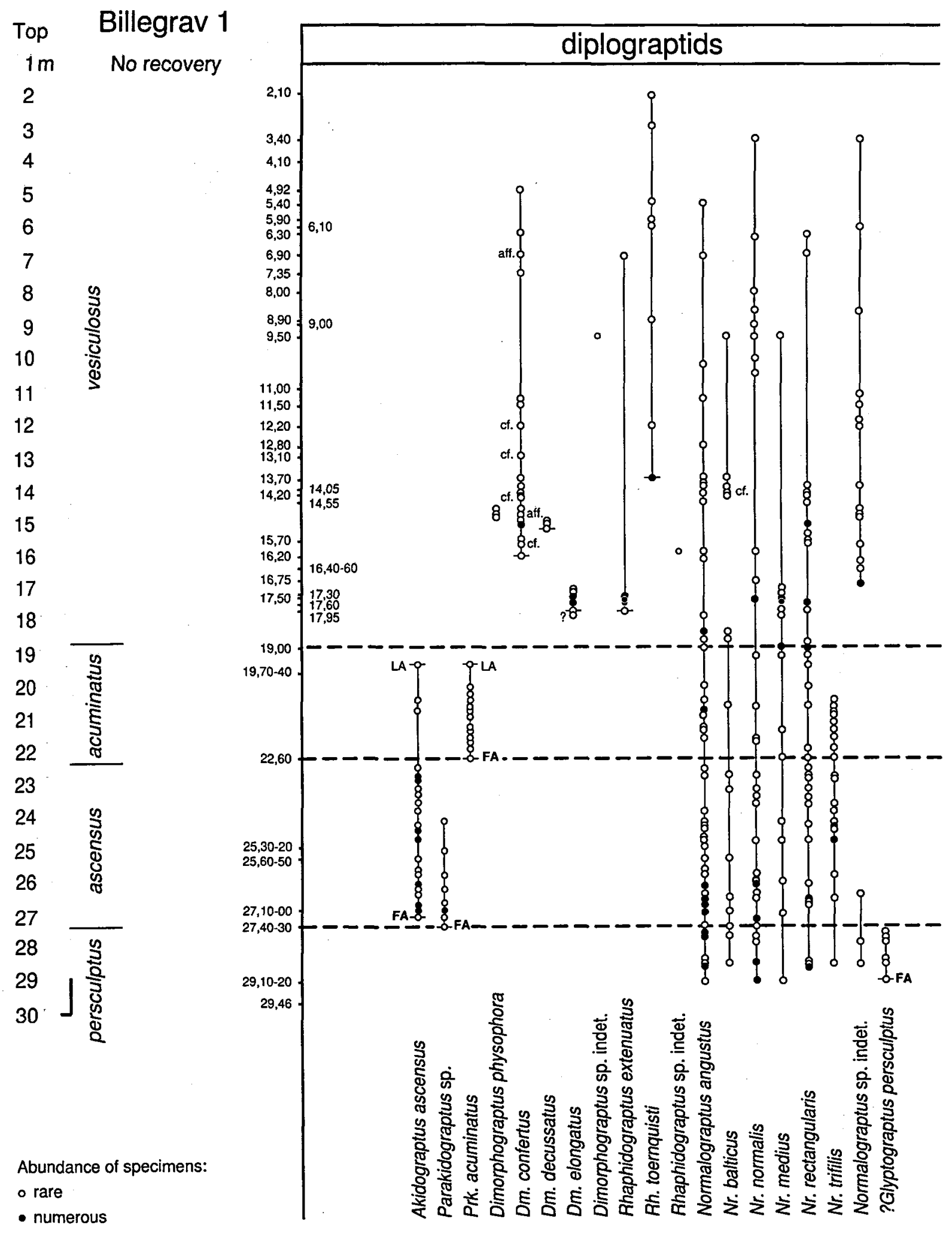

Fig. 4. Stratigraphical distribution of graptolites in the Billegrav-1 core. 


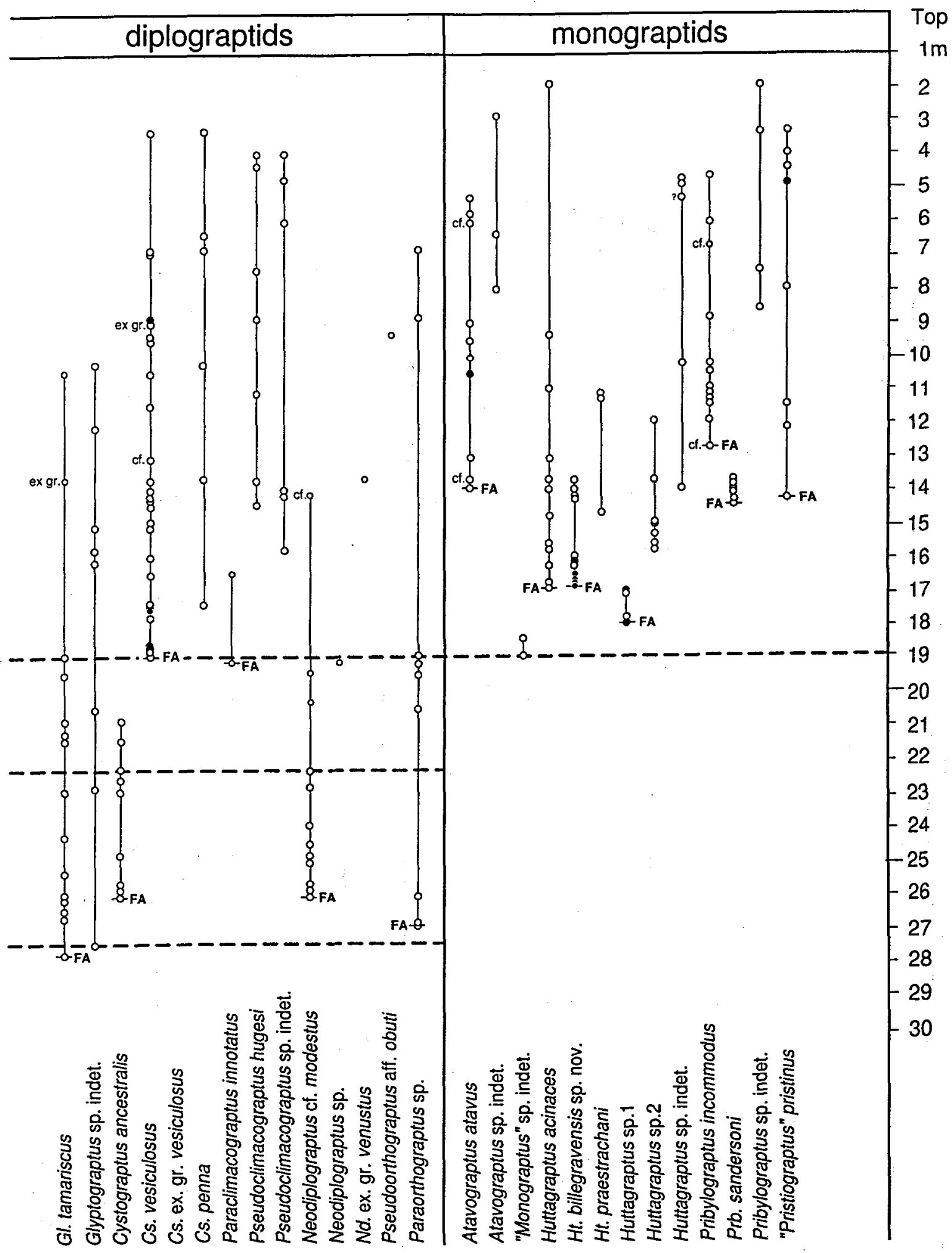


posures caused by the very complicated geological structure. The rocks are strongly deformed, frequently overthrusted and usually exposed within different nappes or in chaotically arranged tectonic slabs. In general, they form a linear belt directed from north to south which is called the Sakmara Zone and are interpreted as the marginal Sakmara allochton which is differentiated in the southern part of the Uralian collisional fold belt (Ruzhentsev \& Samygin 1969).

A relatively detailed plate-tectonic pattern of the southern Urals development was summarized by Zonenshein et al. (1990). This interpretation was adopted and further developed within a broad Eurasian plate-tectonic scenario by Sengör et al. (1993). This latest model shows that the lower Silurian terrigenous-volcanogenic rocks of the Sakmara Formation could have been formed in the paleoequatorial latitudes within the Sakmara-Magnitogorsk marginal sea to the east of East-European plate. The Sakmara trough continued to expand in Early Silurian time and this restricted the supply of terrigenous material to the central parts of the trough. Sedimentation mainly involved the accumulation of the cherty shales of the Sakmara Formation. These are comparable with the bathyal sediments of marginal basins and the island arc complexes. There are no traces of a bottom fauna, and the single preserved biological components of the pelagic ecosystems are numerous graptolites and radiolarians.

\section{Biostratigraphy}

\section{Bornholm}

The complete succession of the persculptus, ascensus, acuminatus and vesiculosus Biozones has been established through a $30 \mathrm{~m}$ thick interval from high-resolution sampling in the Billegrav-1 core (Fig. 4). The investigated part of the core comprises the finely laminated grey to dark-grey shales alternating in some intervals with limestone beds.

The lower part, about $11 \mathrm{~m}$ thick, is characterized by a diplograptid fauna. The long-ranging species of Normalograptus usually dominate. Graptolites, preserved as flattened specimens, are most frequent in the dark grey mudshales. In the upper part of the persculptus Biozone numerous specimens of the index-species are preserved in relief, being infilled with pyrite. This part of the core was thoroughly sampled and $\mathrm{X}$-rayed to find the earliest monograptids, although no specimens were detected.

Based on the first appearences of the zonal species the successive biozones, e.g. the ascensus and acumi-natus Biozones are well defined (Fig. 4). The taxonomic composition of associated diplograptids is similar for both units. It includes long-ranging species and those confined to this interval such as Normalograptus trifilis (Manck) and Cystograptus ancestralis Štorch. Rare specimens of Akidograptus ascensus Davies occur within the whole range of Parakidograptus acuminatus (Nicholson).

The base of the vesiculosus Biozone is defined by the first occurence of the zonal species in association with the earliest Huttagraptus sp. indet. From this level upwards in the section monograptids increase in numbers and diversity. In the interval studied, nine species of monograptids have been identified, belonging to the genera Atavograptus, Huttagraptus gen. nov., "Pristiograptus", Lagarograptus and Pribylograptus. The diagnostic species of Dimorphograptus, Rhaphidograptus and other diplograptids are associated with monograptids through the whole zonal sequence and give a good stratigraphic control. Three species are left in open nomenclature because of incomplete preservation (Fig. 4).

Graptolites are much more abundant in the lower part of the vesiculosus Biozone (depth 18-13 m), where the mudrocks dominate.

The upper part of the vesiculosus Biozone, $10 \mathrm{~m}$ thick, comprises alternating dark grey mudstones and medium grey limestone beds $(5-10 \mathrm{~cm})$. Graptolites occurring in the mudstone layers below the lime rich part of the core are less frequent and fragmentary.

Numerous and well-preserved graptolites of the upper part of the vesiculosus Biozone (= acinaces Biozone, Bjerreskov 1975) have been found in the dark grey mudshales exposed at the bottom of the rivulet $\emptyset$ le $\AA$ (exp. 4a and 2c; Fig. 2).

In exposure $2 c$ numerous monograptids are represented by specimens of Atavograptus atavus (Jones) and "Pristiograptus" pristinus (Hutt). Among the associated diplograptids, Normalograptus normalis (Lapworth) and Cystograptus vesiculosus (Nicholson) are dominant. The graptolites are flattened and on some bedding surfaces they show distinct preferred orientation.

Finely laminated light grey to dark grey mudshales yielding numerous pyritized graptolites are exposed in the locality $4 \mathrm{a}$ (Fig. 2). New, more extensive collections were made for the present study. This locality yields the most complete monograptid assemblage of the upper part of the vesiculosus Biozone. It includes At. atavus, Huttagraptus acinaces (Törnquist), "Pr." pristinus, Pribylograptus incommodus (Törnquist) and Lagarograptus sp. in association with the most important diagnostic diplograptids. In some layers graptolites occur together with very peculiar, but enigmatic structures of organic origin. These organisms show meandering structures, sometimes bifurcating or have regular sinuosity. All these peculiar features are well seen in the X-ray pictures made from the samples (Fig. 5D, E, F). In the opinion of Dr. R. Bromley (1995, pers. communication) some of these structures can be interpreted as trace fossils preserved in situ; others look more like epipelagic tube-like colonial organisms of an uncertain systematic position. 
Table 1 . Zonal associations of the southern Urals graptolites.

\begin{tabular}{|c|c|}
\hline BIOZONE & GRAPTOLITE ASSEMBLAGE \\
\hline cyphus & $\begin{array}{l}\text { Gl. tamariscus nikolaevi, N. normalis, N. rectangularis, Prc. } \\
\text { innotatus, Pseudorthograptus inopinatus, Dittograptus } \\
\text { inconstans }{ }^{*} \text {, Dt. physophora, Dimorphograptus swastosoni, } \\
\text { Rhaphidograptus toernquisti, Metaclimacograptus hughesi, } \\
\text { Mt. undulatus, Monograptus a. austerus, M. revolutus, Ht. ninae } \\
\text { sp. nov., Ht. strachani, Prb. incommodus, Prb. sandersoni, } \\
\text { Lg. inexpeditus, Lg. Karaensis sp. nov. }\end{array}$ \\
\hline vesiculosus & $\begin{array}{l}\text { Gl. bulbus }{ }^{*} \text { Cs. vesiculosus, N. normalis, Prc. innotatus, } D \text {. } \\
\text { erectus, Mt. undulatus, A. atavus, Ht. incurvus sp. nov., Ht. } \\
\text { ninae sp. nov., Ht. praestrachani, Prb. cf. Prb. sandersoni, } \\
\text { Prb. incommodus }\end{array}$ \\
\hline $\begin{array}{l}\text { acuminatus- } \\
\text { ascensus }\end{array}$ & $\begin{array}{l}\text { Neodiplograptus sp., N. cf. N. balticus, N. cf. N. mirnyensis, } \\
\text { N. trifilis, Hirsutograptus longispinus*, Prk. acuminatus, Ak. } \\
\text { ascensus, A. primitivus }\end{array}$ \\
\hline
\end{tabular}

* - new species described by Koren and Rickards (1996)
In exposure $4 \mathrm{a}$ the lower boundary of the overlying revolutus Biozone is established by a distinctive change in the taxonomic composition of graptolites (Bjerreskov 1975). It is recognized by the appearance of Monograptus revolutus Kurck and Coronograptus cyphus (Lapworth).

\section{Southern Urals}

The lower Silurian carbonaceous silicified shales and cherts yielding graptolites are included in the lower part of the Sakmara Formation, which is widely distributed in the Mugodzhary Range of the southern Urals. Continuous sequences within the Sakmara Formation are rarely preserved in extensive stratigraphic exposures. The rocks are deformed and usually exposed within different nappes and tectonic slices, and the real stratigraphic and biostratigraphic sequence can be reconstructed only by using graptolites. The graptolites derive from numerous localities in the KosIstek region between rivers Or' and Ilek (Fig. 3; Leonenok 1955; Koren' 1964, 1967, 1986; Rickards \& Koren' 1974; Urbanek et al. 1982; Koren' \& Rickards 1996). The graptolite-bearing strata usually occur as loose in situ blocks on low, flat hills and alongside small creeks. Therefore, it is impossible to measure continuous sections, but still all the individual collections occur in stratigraphic succession. The collections were made during mapping projects, led by many regional geologists, in which one of the authors (TNK) participated.

The graptolite assemblages of the ascensus-acuminatus, vesiculosus and cyphus Biozones have been established along the Kara-Dzhilga Valley in the KosIstek Region (Table 1). The monograptid species found in this stratigraphic interval are described in the present paper. The associated diplograptid fauna was recently monographed by Koren' \& Rickards (1996).

Comparison of the taxonomic composition of contemporaneous early Llandovery monograptid assemblages in Bornholm and the southern Urals shows the following:

1. Atavograptus primitivus (Li), the single ascensusacuminatus Biozone monograptid species, was recognized only in the deep-water biofacies in the southern Urals and not in the epicratonic, shallower-water biofacies on Bornholm. Previously it was recorded from China and the Canadian Arctic (Li 1990; Lukasik \& Melchin 1994).

2. The vesiculosus Biozone monograptid assemblage in both regions includes several common species of Atavograptus, Huttagraptus and Pribylograptus. Among them are A. atavus, Huttagraptus praestrachani (Hutt \& Rickards), Pribylograptus sandersoni (Lapworth) and Prb. incommodus. All these species are known also from Great Britain, China and the Canadian Arctic. They can be considered as pandemic taxa characteristic of epicratonic and deep-water facies. Yet some new huttagraptids described herein are now known only in one of the studied regions. Ht. acinaces, well represented in the British (acinaces Biozone) and Scandinavian sequences (acinaces Biozone, Bjerreskov 1975; the late vesiculosus Biozone in the present paper) was not recognized in the southern Urals and elsewhere.

4. Lagarograptus inexpeditus (Obut \& Sobolevskaya), first described from the triangulatus Biozone in the northern part of Siberia (Obut et al. 1968 ) is discovered in the cyphus Biozone of the southern Urals. Besides these two regions the spe- 
cies is known only from Canadian Arctic (Melchin 1989).

5. In general, the vesiculosus Biozone monograptids are much more numerically abundant in the epicratonic biofacies as it is shown by the Bornholm sequences. However, they are not a dominant part of the vesiculosus Biozone assemblage in the deep-water biofacies of the southern Urals.

\section{Preservation and terminology of graptolites}

The preservation of graptolites collected from finely laminated grey to dark-grey mudshales at the localities $2 c$ and $4 a$ in Øle $\AA$ varies from flattened specimens to those preserved in three dimensions infilled with pyrite (Bjerreskov 1975, 1991). The 3-D specimens were investigated by X-ray (Fig. 5) and some of them were isolated from the sediments. The new collections from the Billegrav-1 core are represented by flattened rhabdosomes with the periderm replaced by a silvery carbonaceous film. This is often partly flaked off and only thin impressions of the rhabdosomes are seen on the bedding planes. In some bed units graptolites are quite numerous but seldom complete due to the $3.2 \mathrm{~cm}$ diameter of the core. The Uralian graptolites are preserved as flattened rhabdosomes in the carbonaceous silicified shales and cherts. The periderm is not strongly carbonized and in many cases, especially on the weathered surfaces, fuselli and apertural thecal structures are clearly seen. As there is no tectonic deformation of graptolites in any collection studied, accurate measurements of morphological features such as proximal thecae and sicular length can be made. These dimensions are critical for taxonomic differentiation of the early Llandovery monograptids, especially in view of the limited number of diagnostic morphological characters and the extremely narrow proximal part of the rhabdosome.

In the following systematic description the terminology is used in the sense described by Bulman (1970). Some additional terms for morphological characters, introduced by Rickards $(1974,1976)$ and Hutt (1975) are used. In measuring graptolites the present authors followed the standard practice. Thecal spacing was calculated in the traditional way which is the number of thecae in 5 or $10 \mathrm{~mm}$. The range of values for dorso-ventral width of the rhabdosome are given in brackets. The only abbreviation used is "th1, 2, 3 etc." for thecae. Bar scales are $1 \mathrm{~mm}$ unless otherwise stated.

\section{Repository}

The described and figured specimens are in the type collection of the Geological Museum of the University of Copenhagen (prefix MGUH).
Table 2. Systematic list of described graptolites.

Family Monograptidae Lapworth, 1873

Genus Atavograptus Rickards, 1974, emended herein Atavograptus atavus (Jones, 1909)

Atavograptus primitivus $(\mathrm{Li}, 1983)$

Genus Huttagraptus gen. nov.

Huttagraptus praestrachani (Hutt \& Rickards, 1977) in

Rickards et al.1977

Huttagraptus acinaces (Törnquist, 1899)

Huttagraptus billegravensis sp. nov.

Huttagraptus incurvus sp. nov.

Huttagraptus ninae sp. nov.

Huttagraptus strachani (Hutt \& Rickards, 1970)

Huttagraptus sp. 1

Huttagraptus sp. 2

Huttagraptus sp. 3

Genus Pristiograptus Jaekel, 1889

"Pristiograptus" pristinus Hutt, 1975

Genus Pribylograptus Obut \& Sobolevskaya, 1966

Pribylograptus incommodus (Törnquist, 1899)

Pribylograptus sandersoni (Lapworth, 1876)

?Pribylograptus $\mathrm{sp}$.

Genus Lagarograptus Obut \& Sobolevskaya, 1968 in Obut et al, 1968

Lagarograptus inexpeditus Obut \& Sobolevskaya, 1968 Lagarograptus karaensis sp. nov.

\section{Systematic palaeontology}

Family Monograptidae Lapworth, 1873

Genus Atavograptus Rickards, 1974

Type species. - Monograptus atavus Jones, 1909.

Horizon. - Llandovery, Rhuddanian to lower Aeronian, the persculptus Biozone to the argenteus Biozone inclusive.

Diagnosis (emended from Rickards 1974). - Rhabdosome long (at least $300 \mathrm{~mm}$ ), slender $(0.2-1 \mathrm{~mm}$ ) and gently dorsally curved, becoming straight distally. Sicula about 1.3-1.4 mm long with low position for the origin of th1 and with apex reaching to about the aperture of thl. Thecae with slightly everted apertures,

Fig. 5. X-ray photos of pyritized graptolites from exposure $4 \mathrm{a}$ in $\emptyset$ le A. A, B, Atavograptus atavus (Jones, 1909); revolutus Biozone; A, MGUH 24162, fragments of distal parts MGUH 24163; B, MGUH 24164, a proximal fragment with sicula preserved; C, MGUH 24165 "Pristiograptus" pristinus Hutt, 1975; vesiculosus Biozone; D-F, Huttagraptus acinaces (Törnquist, 1899); vesiculosus Biozone; D, MGUH 24166, proximal fragment with sicula preserved; E, MGUH 24167; F, MGUH 24168, fragments of distal parts. Arrows in D-F show problematic trace fossils; D, MGUH 24169; E, MGUH 24169; F, MGUH 24170. All figures are $\times 10$. 


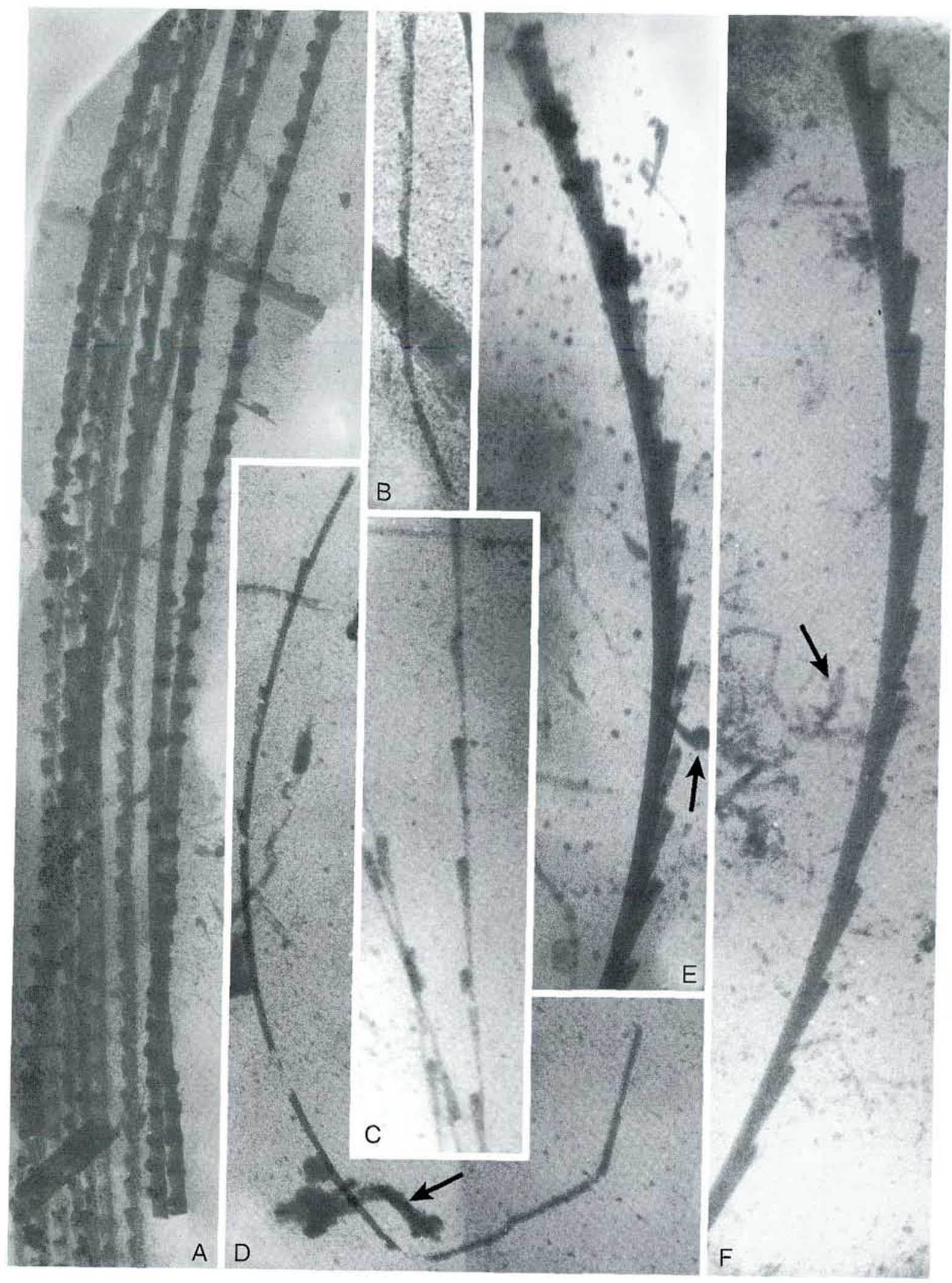


Table 3. Monograptid dimensions

\begin{tabular}{|c|c|c|c|c|c|c|c|c|c|}
\hline & \multicolumn{2}{|c|}{$\begin{array}{l}\text { thecal spacing } \\
\text { in } 10 \mathrm{~mm}\end{array}$} & \multirow[t]{2}{*}{$\begin{array}{l}\text { length } \\
\text { of sicula }\end{array}$} & \multicolumn{2}{|c|}{ rhab. width } & \multicolumn{2}{|l|}{$\begin{array}{l}\text { thecal } \\
\text { overlap }\end{array}$} & \multicolumn{2}{|l|}{$\begin{array}{l}\text { thecal } \\
\text { length }\end{array}$} \\
\hline & p. & d. & & p. & d. & p. & d. & p. & $\mathrm{d}$. \\
\hline \multicolumn{10}{|l|}{ Atavograptus } \\
\hline A. atavus & $6-7$ & $9-10$ & & $0.2-0.3$ & $1.2-1.4$ & $1 / 5$ & $1 / 2$ & & 2 \\
\hline A. primitivus & $9-9,5$ & $7-8$ & $1.7-1.75$ & $0.25-0.3$ & $0.36-0.4$ & $1 / 5$ & $1 / 3$ & $1.4-1.8$ & $1.6-1.7$ \\
\hline \multicolumn{10}{|l|}{ Huttagraptus } \\
\hline Ht. praestrachani & $9-10$ & $7-8$ & 2.4 & $1.5-0.2$ & 0.8 & & $1 / 3-1 / 2$ & & $1.7-2.0$ \\
\hline Ht. acinaces & $4-5$ & $6-7$ & 7 & $0.2-0.25$ & $1.35-1.45$ & $1 / 2$ & $2 / 3$ & & \\
\hline Ht. billegravensis n. sp. & $6.5-7.5$ & 8.5 & $3.5-3.7$ & 0.25 & 0.8 & $1 / 5$ & $1 / 4$ & $2,2-2$ & \\
\hline Ht. incurvus n. sp. & 10 & & $2 ?$ & 0.25 & 0.45 & $1 / 3$ & $1 / 2$ & & \\
\hline Ht. ninae n. sp. & 9 & & $3.7-3.8$ & 0.2 & $0.3-0.4$ & $1 / 3$ & & $1.7-1.8$ & 1.35 \\
\hline Ht. strachani & $7-8$ & & $>3$ & 0.3 & 0.5 & $1 / 5$ & $1 / 3$ & $1.6-1.7$ & 2.00 \\
\hline Huttagraptus sp. 1 & $5.5 / 5$ & $8.5-9$ & & 0.2 & $0.6-0.7$ & & & & \\
\hline Huttagraptus sp. 2 & $6.5-7.5$ & $5.5-6.5$ & $2.1-2.2$ & 0.24 & $0.6-0.7$ & & $1 / 4$ & & $2.1-2.2$ \\
\hline Huttagraptus sp. 3 & $6-7$ & 8 & 2 & 0.28 & 0.55 & $1 / 5$ & $1 / 3$ & 2 & $1.8-2$ \\
\hline \multicolumn{10}{|l|}{ Pribylograptus } \\
\hline Prb. incommodus & 7 & 8 & & 0.5 & 0.65 & $<1 / 2$ & $2-3$ & & \\
\hline Prb. sandersoni & 6.5 & $7.5-8.5$ & $1.8-2.0$ & 0.14 & 0.6 & $1 / 8$ & $1 / 3$ & 2.0 & 1.6 \\
\hline Pribylograptus sp. & & $8-9$ & 1.0 & 0.15 & 0.3 & $1 / 2$ & & & 2.5 \\
\hline \multicolumn{10}{|l|}{ Lagarogratus } \\
\hline Lg. inexpeditus & 8 & & $>4$ & $0.35-0.4$ & $0.5-0.55$ & $>1 / 3$ & & & \\
\hline Lg. karaensis n. sp. & 8 & & 1.9 & 0.48 & 0.65 & $>1 / 3$ & 1.6 (th1) & & \\
\hline \multicolumn{10}{|l|}{ Pristiograptus } \\
\hline " $P$." pristinus & 6 & $5.5-6$ & $>0.9$ & 0.15 & 0.23 & $1 / 10-1 / 12$ & & 1.9 & $1.9-2.0$ \\
\hline
\end{tabular}

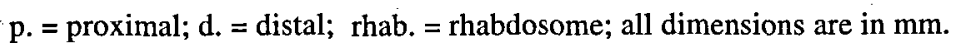

gently convex free ventral walls or flowing geniculum.

Remarks. - The taxonomy and evolutionary relationships of the early monograptids advance were considered by the significant investigations of Hutt and R.B. Rickards (Hutt 1968; Hutt \& Rickards 1970, Rickards \& Hutt 1970; Rickards 1974, 1976; Rickards et al. 1977). Since then, localities yielding some new species have been discovered in China (Chen \& Lin 1978; Li 1990; Ye 1994) and recently in Bornholm and the southern Urals. Present knowledge of morphology and stratigraphic distribution shows that within the Atavograptus plexus (sensu Rickards 1974) two distinctive species groups can be recognized. The first, included within Atavograptus s.s., are At. ceryx, At. primitivus and At. atavus, species which have glyptograptid thecal style, and comparatively short siculae and thecae. The second group is characterized by the proximal introduction of strongly geniculated thecae with genicular rims and/or well developed genicular flanges. It embraces the stratigraphically younger species from the vesiculosus Biozone which are assigned to Huttagraptus gen. nov. Among them are $H t$. praestrachani (type species), Ht. acinaces, $H t$. billegravensis sp. nov., Ht. strachani, Huttagraptus sp. 1, and Huttagraptus sp. 2., Huttagraptus sp. 3., described herein.

Atavograptus atavus (Jones, 1909)

Figs 5A, B; 6, 7A-D, F

1909 Monograptus atavus sp. nov.; Jones, p. 531, textfig. $18 \mathrm{a}-\mathrm{d}$.

1975 Monograptus atavus Jones; Bjerreskov, p. 44, pl. 6, figs G-H (see synonymy).

1975 Atavograptus atavus (Jones); Hutt, p. 62-63, pl. 11, fig. 1; pl. 12, figs 5, 9, 10.

1986 Atavograptus atavus (Jones); Štorch, pl. 6, figs $1-4$.

1988 Atavograptus atavus (Jones); Štorch, p. 12-13, pl. 1, figs 1, 2, 3; text-fig. 2A.

Type. - Lectotype, by subsequent designation by Přibyl \& Spasov (1955), p. 195, figured by Jones (1909), text-fig. 18b; GSM 23710; from the Llandovery of the Rheidol Gorge, Mid-Wales.

Material. - About 100 specimens, both flattened and preserved in relief from the exposures $2 c, 4$ and $4 a$, in $\emptyset$ le $\AA$, more than 20 flattened fragments from the Billegrav-1 core, depth $5.40 \mathrm{~m}-14.00 \mathrm{~m}$, Bornholm; 
and a few specimens from the Kos-Istek region, the southern Urals.

Description. - Rhabdosome more than $100 \mathrm{~mm}$ long, proximally with gentle dorsal curvature becoming straight distally. The maximum dorso-ventral width is $1.2-1.4 \mathrm{~mm}$. The most proximal fragments are 0.4$0.5 \mathrm{~mm}$ wide, in the mesial part of the rhabdosome the dorso-ventral width increases to $0.2 \mathrm{~mm}$ within a distance of about $40 \mathrm{~mm}$. However, the extreme distal fragments, $30 \mathrm{~mm}$ long, have uniform width.

Thecae are simple tubes which increasing overlap from $1 / 5$ proximally to $1 / 2$ distally. The straight thecal apertures are everted throughout. The proximal thecae have a smooth geniculum, which becomes slightly more pronounced in mesial and distal parts of the rhabdosome. The angle of thecal inclination increases from $5^{\circ}$ to $10^{\circ}-15^{\circ}$ towards the distal end. The maximum length of the distal thecae is $2 \mathrm{~mm}$, the width of apertures is $0.5-0.6 \mathrm{~mm}$. The thecal count increases from 6-7 to $9-10$ in $10 \mathrm{~mm}$ distally.

Remarks. - The thecae and dimensions of the present specimens agree well with material described from Wales and Lake District (Hutt 1975), although they lack the extreme proximal end. We found only one specimen with a sicula despite extensive X-ray analysis of samples yielding abundant fragments of At. atavus from the exposure $4 \mathrm{a}$ in $\emptyset$ le $\AA$ (Fig. $5 B$ ).

Atavograptus primitivus ( $\mathrm{Li}, 1983)$.

Figs 7E, G; 8, 9

1983 Pristiograptus primitivus sp. nov.; Li (in Yang et al. 1983), p. 499-500, pl. 173, figs 12, 13.

1990 Atavograptus primitivus (Li); Li, p. 210, pl. 1, figs 12,13 ; text-fig. $1 \mathrm{~g}$.

1990 Pristiograptus antiquatus sp. nov.; Li, p. 215216, pl. 1, figs 8-11, text-fig. 1e-f.

1994 Atavograptus primitivus (Li); Lukasik \& Melchin, p. 1160-1162, figs 1, 3, 4.

Type. - Not designated.

Material. - More than 35 flattened but well preserved rhabdosomes at different astogenetic stages from exposures $671 / 1,671 / 2$ and $671 / 8$ in the Kos-Istek region, the southern Urals.

Fig. 6. A-D, F, Atavograptus atavus (Jones, 1909), fragments of different parts of rhabdosomes, vesiculosus Biozone, Øle Å, Bornholm; A, MGUH 24172, sample 5; B, MGUH 24173, exp. 2c; C, MGUH 24174; D, MGUH 24175, exp. 2c; E-F, Billegrav-1 core, depth $14.00 \mathrm{~m}$; E, MGUH 24176; F, MGUH 24177.
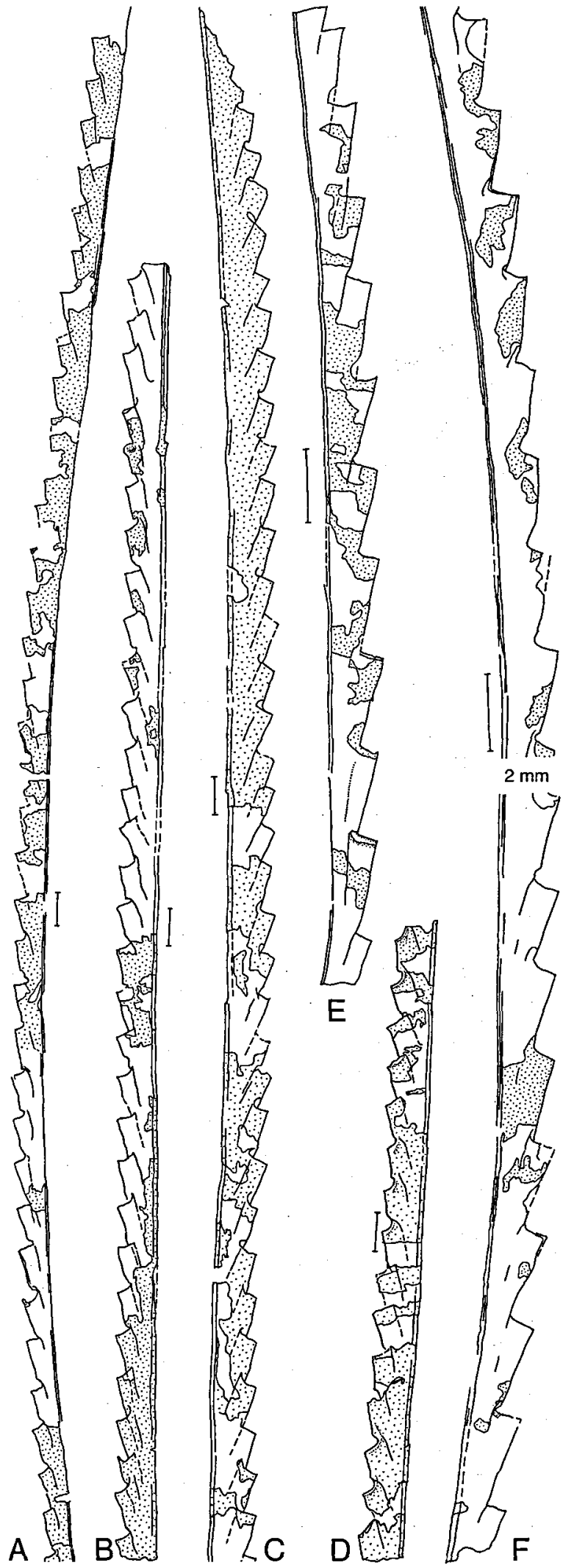

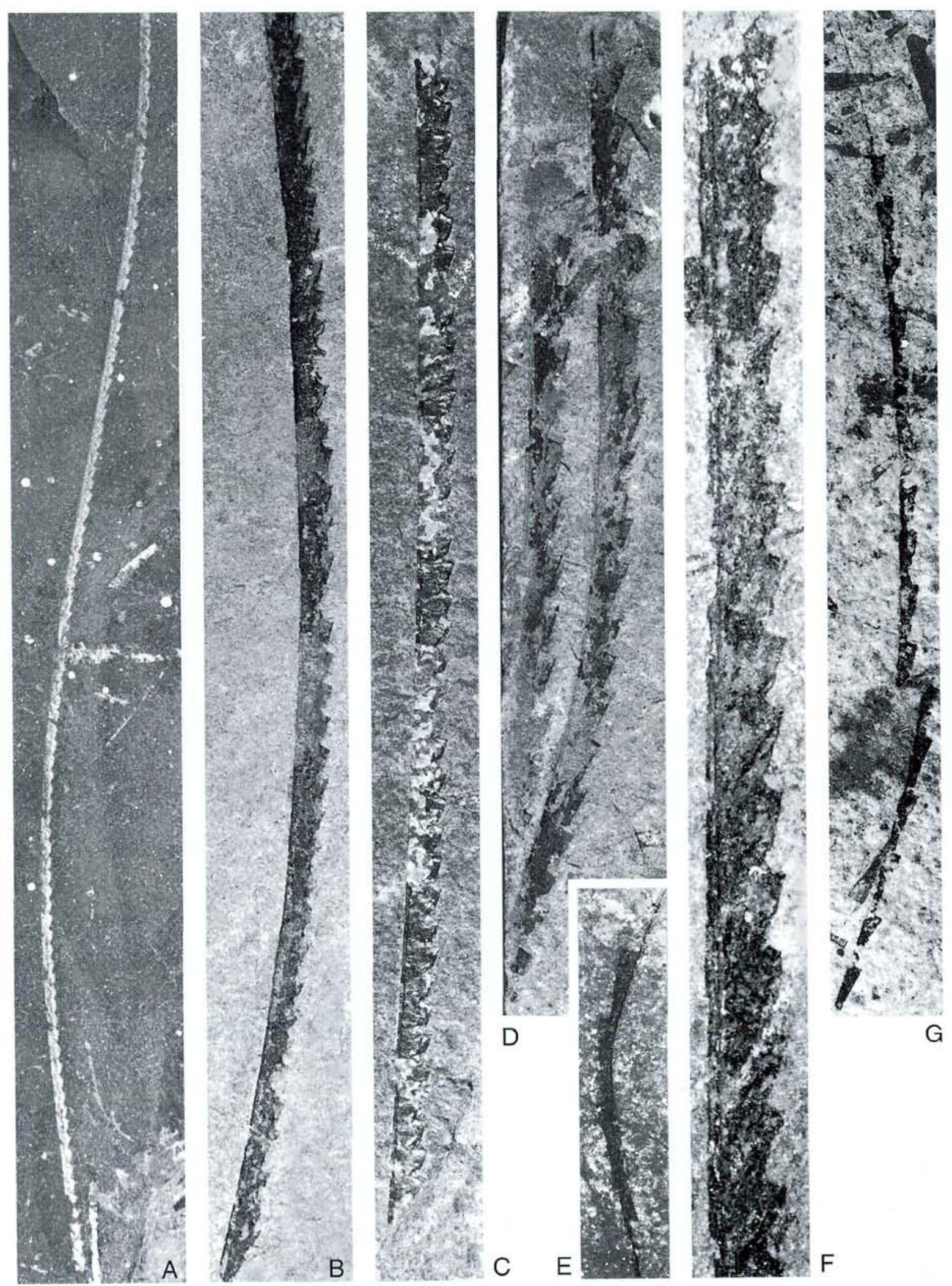
Description. - The rhabdosome with a gentle dorsal curvature, more than $20 \mathrm{~mm}$ long. The dorso-ventral width at th 1 is $0.25-0.30 \mathrm{~mm}$ and the maximum of $0.36-0.4 \mathrm{~mm}$ is attained between th 3 and th5. A long (more than $5 \mathrm{~mm}$ ) thread-like nema is characteristic of the early astogenetic stages (Figs 8,9).

The thecae have horizontal to slightly everted apertures with thickened apertural rims. A flowing geniculum is present, but not always seen in the flattened material. The free ventral walls are almost straight throughout the most of their length and are inclined at $6^{\circ}-8^{\circ}$ to the rhabdosome axis proximally and at $10^{\circ}$ distally. The thecal overlap increases from $1 / 5$ to less than $1 / 3$ towards the distal end. The distal thecae are $1.6-1.7 \mathrm{~mm}$ long and $0.2 \mathrm{~mm}$ wide at the aperture. The thecal count is $9-9.5$ in $10 \mathrm{~mm}$ proximally and 7-8 distally.

The sicula is $1.7-1.75 \mathrm{~mm}$ in length of which about $0.4 \mathrm{~mm}$ comprises the prosicula. The sicula aperture is in general $0.2 \mathrm{~mm}$ wide, in some cases it attains 0.3 $\mathrm{mm}$. In many specimens a thread-like virgella, $3 \mathrm{~mm}$ long, is present. The sicula apex is usually situated below the th1 aperture, sometimes it is very close to the aperture. Th1 originates at a distance of $0.4 \mathrm{~mm}$ $(0.6 \mathrm{~mm})$ above the sicula aperture and attains a length of $1.4-1.8 \mathrm{~mm}$.

Remarks. - The rhabdosome structure, dimensions and thecal shape of the present specimens leave no doubt that they can be assigned to At. primitivus. The Uralian form shows a distinct variation in the position of th 1 bud and the th1 length, which results in a slightly different position of the sicular apex respectively to the th1 aperture. This variation shows that the Uralian form embraces the diagnostic features of two species, At. primitivus and "Pristiograptus" antiquatus $\mathrm{Li}$, described from the local Parakidograptus primarius Biozone of China. This supports the conclusions made by Lukasik and Melchin (1994) that At. antiquatus is a junior synonym of At. primitivus. The latter resembles the earliest monograptid, Atavograptus ceryx Hutt \& Richards especially in the size of the sicula, the length of th 1 and the dorso-ventral width of the rhabdosome. It differs, however, in having longer and more widely spaced thecae with everted apertures, a less distinct geniculum, a higher position of th1 bud, a lower position of sicular apex and extremely long

Fig. 7. A-D, F, Atavograptus atavus (Jones, 1909), distal fragments; vesiculosus Biozone; A, MGUH 24178; B, MGUH 24179; C, MGUH 24180; D, MGUH 24181; F, MGUH 24183; A-C, exp. 2c, Øle $\AA, \times 2.5$; B-D, exp. 4, Øle $\AA, \times 5 ; \mathrm{F}, \mathrm{MGUH} 24183$, exp. 671/8, Kara-Dzhilga, the southern Urals, $\times 10$; E-G: Atavograptus primitivus (Li, 1983), proximal and distal fragments; exp. 671/8, KaraDzhilga; ascensus-acuminatus Biozone; E, MGUH 24282; G, MGUH 24184, × 10 .
virgella.:-Atavograplus primitivus can be compared with the proximal part of the rhabdosome of At. atavus. Atavograptus primitivus has straighter thecae, longer sicula (1.7-1.75 mm as to compare with $1.2-1.4 \mathrm{~mm}$ ) and its dorso-ventral width does not exceed $0.4 \mathrm{~mm}$ at a distance of $20 \mathrm{~mm}$ from the sicula.

\section{Genus Huttagraptus gen. nov.}

Derivation of name. - In honour of Dr. J. E. Hutt, who made significant contributions to the studies of the early Llandovery monograptids.

Type species. - Atavograptus praestrachani Hutt and Rickards, 1970 in Rickards et al. 1977.

Horizon. - Llandovery, Rhuddanian, the vesiculosus to cyphus Biozones.

Diagnosis. - Species possessing a long and slender rhabdosome with strong to slight dorsal curvature. Thecae geniculate in proximal or mesial parts of the rhabdosome, in some species throughout the whole rhabdosome. Pronounced geniculum may have genicular flanges overhanging apertures. Proximal thecae with straight horizontal apertures, semicircular or slitlike excavations; metathecal ventral walls are parallel or slightly inclined to the dorsal side of the rhabdosome. Gradual changes such as lessening of geniculum, increase in thecal inclination (up to $5^{\circ}-10^{\circ}$ ) and inversion of thecal apertures take place towards the distal end. Sicula usually long (more than $3 \mathrm{~mm}$ ) with high position for the origin of th 1 .

Remarks. - The arbitrary inclusion of species such as "Monograptus" strachani in Atavograptus and not into Monoclimacis was discussed by Rickards (1974). The present extensive collection of so-called atavograptids from the vesiculosus Biozone in the Billegrav1 core and in the southern Urals provided more knowledge about the morphology of previously known and some new species described herein. They constitute a morphologically separate group of species and it seems to be justifiable to group them into a new genus Huttagraptus. They have geniculated thecae with thickened rim and flanges within the main part of the rhabdosome and share a tendency to a distinctive lessening of the geniculum towards the distal end. The characteristic monoclimacid-like thecal shape combined with the long sicula and the high position for the origin of th1 are enough to exclude such species as gracilis, praestrachani and strachani from Atavograptus and to assign them to this new genus Huttagraptus. This genus embraces as well the following taxa: Ht. acinaces, $H t$. billegravensis sp. nov, $H t$. incurvus sp. nov., Huttagraptus sp. 1, Huttagraptus sp. 2 and Huttagraptus sp. 3. The species assigned to Huttagraptus differ in thecal spacing and overlap, length 


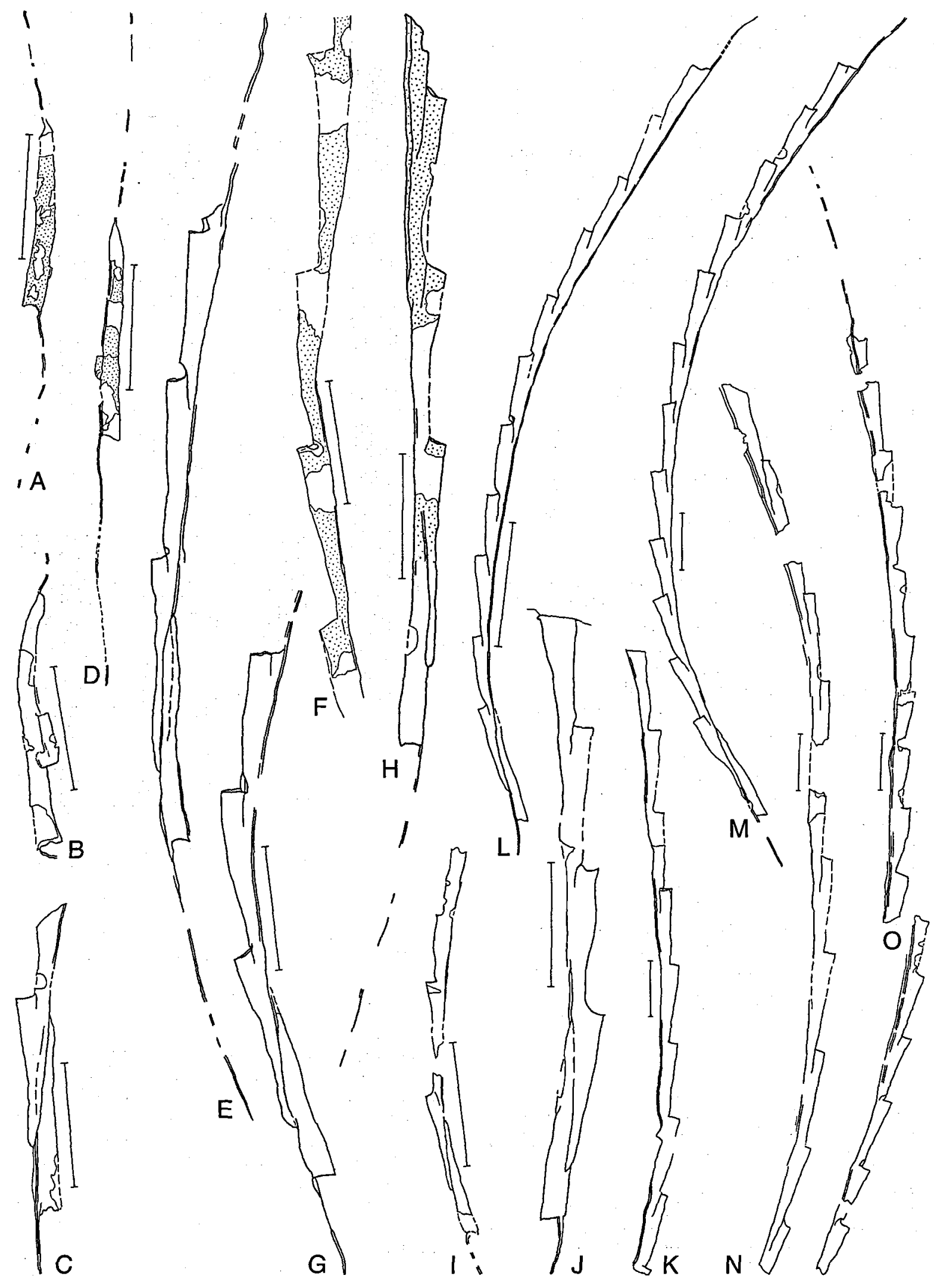


of sicula and th 1 as well as in the position of the origin of th1. Thus, the specific differentiation requires well preserved and complete material as far as the proximal part of the rhabdosome is concerned. The distal parts of the rhabdosomes referred to Huttagraptus $\mathrm{sp}$. , Ht. billegravensis, Ht. praestrachani and Ht. strachani are difficult to differentiate. From its thecal style Huttagraptus gen. nov. can be considered as a morphologically transient genus between Atavograptus and Lagarograptus. The latter develops distinct genicular flanges, slightly expanded apertures, often in combination with ventral processes. Huttagraptus gen. nov. is distinguished from Monoclimacis by the elongated extreme proximal part of the rhabdosome and less geniculate distal thecae.

Huttagraptus praestrachani (Hutt \& Rickards 1977) in Rickards et al. 1977

Figs 10A-I, 16A-E

1970 Monograptus sp. 1; Hutt \& Rickards, p. 75-76, fig. $3 \mathrm{c}, \mathrm{d}$.

1977 Atavograptus praestrachani sp. nov.; Rickards et al., p. 102-103, fig. 17, p. 37.

Type. - Holotype figured by Hutt \& Rickards (1970), fig. 3c, N A 60415, SM from Keisley (National Grid ref. NY 71382379), the atavus Biozone.

Material. - 12 fragmentary specimens preserved as flattened from the Billegrav-1 core, depth 15.20-14.70 $\mathrm{m} ; 17$ flattened specimens, mostly proximal and mesial parts of rhabdosomes from the southern Urals, Kos-Istek region, localities 477, 671/1, 671/8, 671/9, $1500 / 47$ and 1643, the vesiculosus Biozone.

Description. - The fragments are 10-20 mm long, with variable dorsal curvature in the proximal part. The dorso-ventral width increases slowly from $0.15-0.2$ $\mathrm{mm}$ at th1 to $0.25-0.30 \mathrm{~mm}$ at th5, the most distal fragments are $0.8 \mathrm{~mm}$ wide.

The thecae are distinctly geniculate, the feature is emphasized by the presence of genicular rims. The horizontal or slightly everted apertures open into slitlike excavations, which occupy $1 / 3$ or even $1 / 2$ of the dorso-ventral rhabdosome width. Apertural margins

Fig. 8. Atavograptus primitivus (Li, 1983); ascensusacuminatus Biozone, exp. 671/8-74, Kara-Dzhilga, the southern Urals. A-E, G, early astogenetic stages; A, MGUH 24185; B, MGUH 24186; C, MGUH 24187; D, MGUH 24188; E, MGUH 24189; F, MGUH 24190; G, MGUH 24191; H, I, J, proximal fragments; H, MGUH 24192; I, MGUH 24193; J, MGUH 24194; K, N, O, fragments with no sicula; K, MGUH 24195; N, MGUH 24198; O, MGUH 24199; L, M, complete rhabdosomes; L, MGUH 24196; M, MGUH 24197.
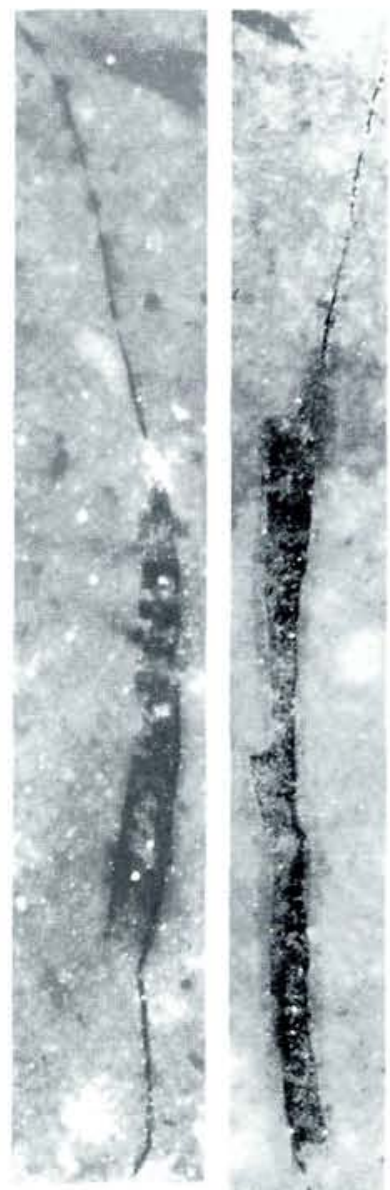

A
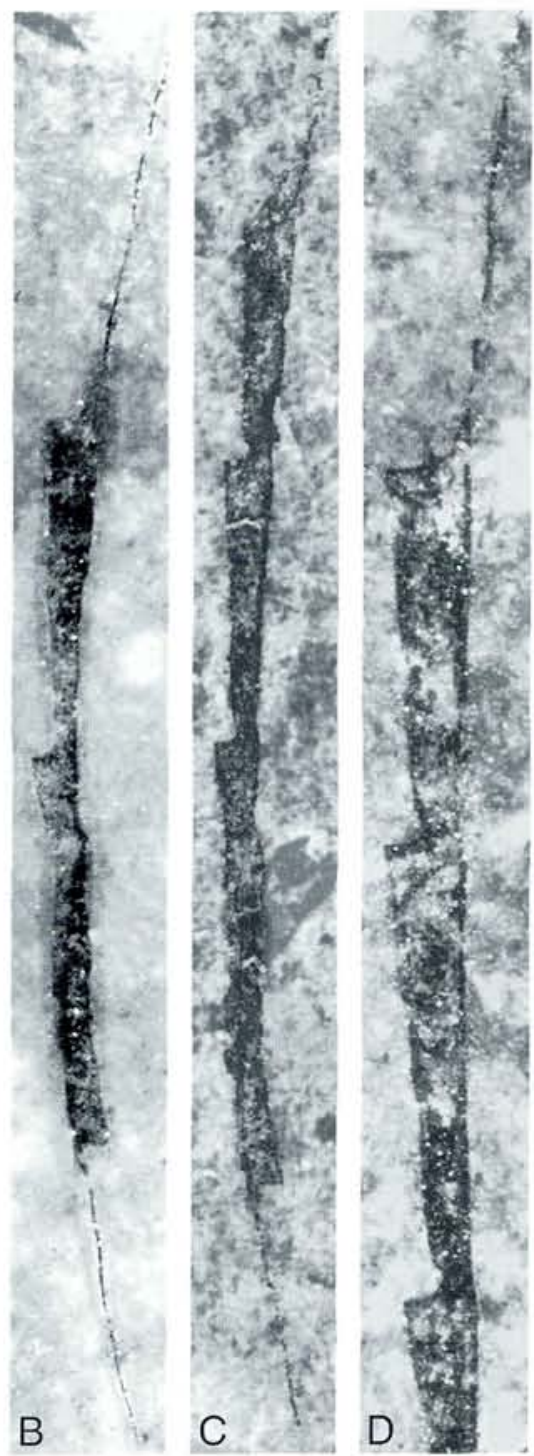

Fig. 9. Atavograptus primitivus $(\mathrm{Li}, 1983)$; ascensus-acuminatus Biozone, exp. 671/8, Kara-Dzhilga. A-C, specimens showing early astogenetic stages; D, distal fragment. A, MGUH 24200; B, MGUH 24201; C, MGUH 24202; D, MGUH 24203; A, D, × 40; B, C, $\times 20$.

are usually thickened, which is especially well seen in the Uralian specimens. The supragenicular walls are straight and almost parallel to the dorsal side of the rhabdosome, distally they are inclined at no more than $5^{\circ}$. The most distal thecae are $1.7-2.0 \mathrm{~mm}$ long, $0.2 \mathrm{~mm}$ wide at the apertures and overlap $1 / 3$ to $1 / 2$ of their length. They show weaker geniculum, more open aperture and no traces of genicular flanges. Thecal count is $9-10$ in $10 \mathrm{~mm}$ proximally and $7-8$ in $10 \mathrm{~mm}$ distally.

Sicula is up to $2.4 \mathrm{~mm}$ long and $0.2 \mathrm{~mm}$ wide at the 

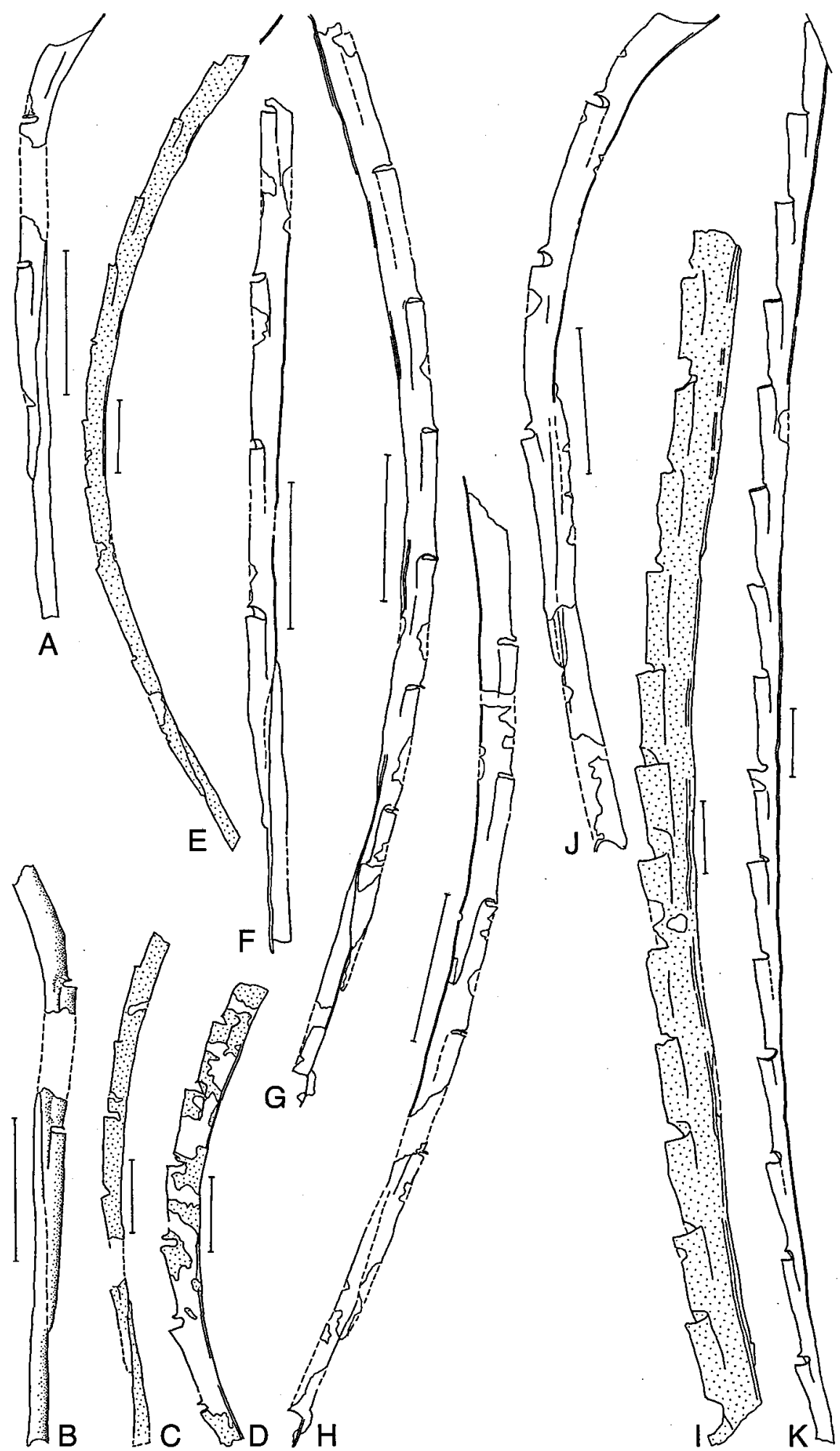

Fig. 10. A-I, Huttagraptus praestrachani (Hutt \& Rickards, 1977), vesiculosus Biozone. A-C, F, proximal fragments; A, MGUH 24204; B, MGUH 24205, exp. 477, Kos-Istek region; C, MGUH 24206, exp. 671/8, Kara-Dzhilga; F, MGUH 24209, Billegrav-1 core, sp. 1, depth $15.20 \mathrm{~m}$; D, I, rhabdosome fragments; D, MGUH 24207, depth 11.20-11.35 m; I, MGUH 24212, exp. 671/8; E, G, H, complete rhabdosomes; E, MGUH 24208, exp. 671/8, Kara-Dzhilga; G, MGUH 24210, exp. 1643, Kos-Istek region; H, MGUH 24211, exp. 1643; J, K, Huttagraptus strachani (Hutt \& Rickards, 1970), cyphus Biozone, exp. 671/8, Kara-Dzhilga, the southern Urals; J, MGUH 24213; K, MGUH 24214. 


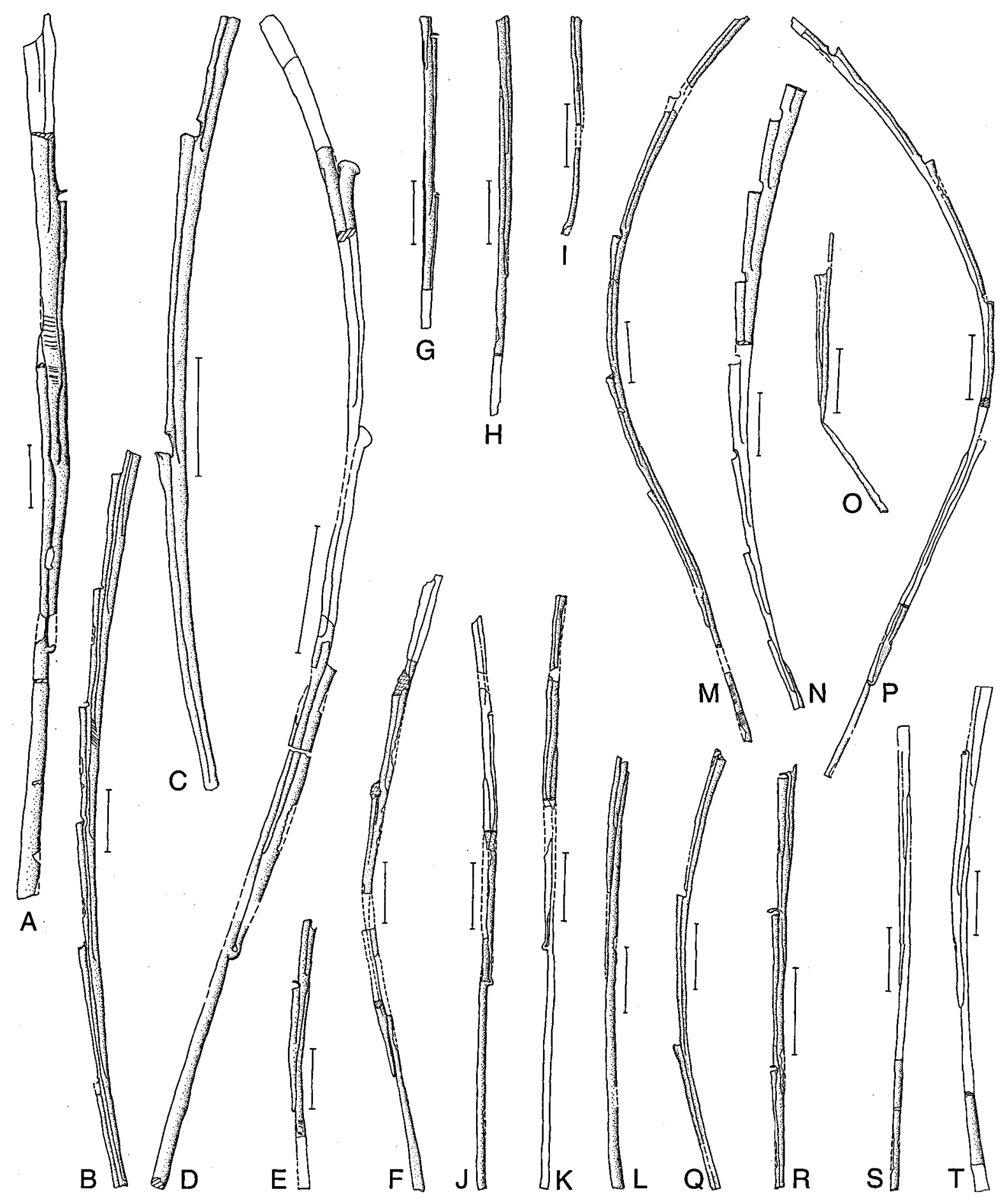

Fig. 11. Huttagraptus acinaces (Törnquist, 1899), A-S, proximal fragments, upper part of the vesiculosus Biozone, Øle $\AA$, exp. 4a; A, MGUH 24215; B, MGUH 24216; C, MGUH 24217; D, MGUH 24218; E, MGUH 24219; F, MGUH 24220; G, MGUH 24221; H, MGUH 24222; I, MGUH 24223; J, MGUH 24224 a; K, MGUH 24224 b; L, MGUH 24225 ; M, MGUH 24226; N, MGUH 24227; O, MGUH 24228; P, MGUH 24229; Q, MGUH 24230; R, MGUH 24231; S, MGUH 24232; T, LO, sp. 1436T, Törnquist, 1899, pl. 1, figs 7, 8. 
aperture. The position of the apex varies from a level slightly below to slightly above the th 1 aperture. Th 1 originates at a distance about $0.65-0.75 \mathrm{~mm}$ above the sicular aperture and it attains a length of 1.35$1.55 \mathrm{~mm}$.

Remarks. - The thecal structure of the current specimens resemble closely Ht. strachani, as does the shape of the rhabdosome and the attenuated extreme proximal end. The distinct change of the thecal count from 10 to 7 in $10 \mathrm{~mm}$ towards the distal end agrees well with that mentioned in the original description (Rickards et al. 1977). However, the sicula preserved in the few specimens studied does not reach $3 \mathrm{~mm}$ in length, typical for Ht. strachani.

Huttagraptus acinaces (Törnquist 1899)

Figs 5D, E, F; 11, 12, 13

1899 Monograptus acinaces n. sp.; Törnquist, p. 5, pl. 1, figs 7, 8 .

1970 Monograptus acinaces Törnquist; Hutt \& Rickards, p. 76, text-fig. 3i-j.

1975 Monograptus acinaces Törnquist; Bjerreskov, p. $45-46$, fig. $14 \mathrm{C}$, pl. 6 , fig. I.

1975 Lagarograptus acinaces (Törnquist); Hutt, p. 69, pl. 13, figs 5-6; text-fig. 16, figs 1-3.

Type. - Holotype figured by Törnquist (1899), pl. 1, figs 7, 8; LO 1436t and refigured herein, Figs 11T, $12 \mathrm{H}$; from the Llandovery of Röstånga, Scania.

Material. - More than 100 well preserved specimens, pyritized in $3 \mathrm{~d}$ and in low relief at all astogenetic stages; exp. 4, (Bjerreskov 1975) and 4a in Øle §̊; 25 flattened specimens, mostly mesial and distal fragments treated as Ht. cf. Ht. acinaces from the Billegrav-1 core, depth $2.10-16.75 \mathrm{~m}$.

Description. - The rhabdosome is more than $50 \mathrm{~mm}$ long, broadly dorsally curved proximally and becoming more straight distally. The proximal end and the first 5-10 thecae are extremely narrow. Successive measurements of dorso-ventral width are as follows: at th1 $0.2-0.25 \mathrm{~mm}(0.16 \mathrm{~mm} ; 0.3 \mathrm{~mm}), 2 \mathrm{~mm}(0.28$ $\mathrm{mm})$, th3 $0.2-0.24 \mathrm{~mm}(0.34 \mathrm{~mm})$ and th $40.27 \mathrm{~mm}$ $(0.37 \mathrm{~mm})$, between th 10 and th $150.6-0.8 \mathrm{~mm}$. The rhabdosome attains the maximum dorso-ventral width of $1.35-1.45 \mathrm{~mm}$ at the distal end.

The proximal thecae are long and slender, overlapping one half of their length. Distinct variation in thecal overlap within the rhabdosome is present. In the majority of specimens a horizontal line at the level of the th1-th2 apertures crosses one septum, and further on, in the mesial part of the rhabdosome it crosses two septa. There are, however, specimens in which a horizontal line drawn across the level of a thecal aperture in the proximal part crosses no interthecal septa.
The proximal and mesial thecae have slightly expanded and everted apertures, straight supragenicular walls except for the small but distinct geniculum which occasionally gives rise to a genicular flange, $0.01 \mathrm{~mm}$ long (Figs 11 A, B, R; 12C, D, I). In general the thecal overlap increases up to $2 / 3$ within the first $15-20 \mathrm{~mm}$ of the rhabdosome length. The thecae slowly increase in width from $0.12 \mathrm{~mm}$ at the prothecal aperture to the subapertural part of the metatheca where a width of $0.23-0.24 \mathrm{~mm}$ is suddenly reached. Interthecal septa are almost parallel to each other, though straight ventral walls are inclined at $5^{\circ}$ in the proximal part and up to $10^{\circ}$ distally. The proximal and mesial thecae show broad and open excavations. In the most distal fragments there is only a slight suggestion of a weak geniculum and the thecae are generally straight tubes overlapping for about $2 / 3$ of their length, with distinctly everted and straight apertures. The thecal count increases from $4-5$ in $10 \mathrm{~mm}$ proximally to $6-7$ in 10 $\mathrm{mm}$ distally.

The extremely long and narrow sicula attains a maximum length of more than $7 \mathrm{~mm}$, the apertural width reaches $0.23-0.24 \mathrm{~mm}$. Th1 originates at a distance of $3 \mathrm{~mm}$ above the aperture of the sicula. A short horizontal component of initial growth of th 1 is well seen in some pyritized specimens preserved in full relief (Fig. 11A, D, J, K). The same feature, unusual for monograptids, is present in the earliest huttagraptids, such as Ht. billegravensis. The sicula is more than 7 $\mathrm{mm}$ long. The apex does not reach the th1 aperture and it is usually slightly below or above the base of the septum between th1 and th2. The protheca of th1 and the apical part of sicula overlap at a distance of 3-4 mm (2.1-2.3 mm).

Remarks. - "Monograptus" acinaces Törnquist was assigned by Hutt (1975) and Rickards (1976) to Lagarograptus after the discovery of ventral processes at a single distal fragment of Monograptus rheidolensis Jones from Wales, considered by them to be a synonym of " $M$." acinaces (Hutt \& Rickards 1970, textfig. 3j). The present authors studied the type material of Törnquist (1899), housed in the Geological Institute in Lund, of which some specimens are refigured

Fig. 12. Huttagraptus acinaces (Törnquist, 1899), vesiculosus Biozone, Øle $\AA$, exp. 4a. A-G, distal fragments with strongly overlapping thecae; A, MGUH 24233; B, MGUH 24234; C, MGUH 24235; D, MGUH 24236; E, MGUH 24237; F, MGUH 24238; G, MGUH 24239; H, I, adult rhabdosomes; H, LO 1436T, 1437T, Törnquist, 1899, pl. 1, figs 7, 8; I, MGUH 24240, I1, I2 and I3 details of proximal end and thecal structure of the same specimen.

Fig. 12/1. Huttagraptus cf. acinaces (Törnquist, 1899), distal fragments, Billegrav-1 core, vesiculosus Biozone; A, MGUH 24241, depth 16.75 m; B, MGUH 24242, depth $16.90 \mathrm{~m}$; C, MGUH 24243, depth $16.75 \mathrm{~m}$. 


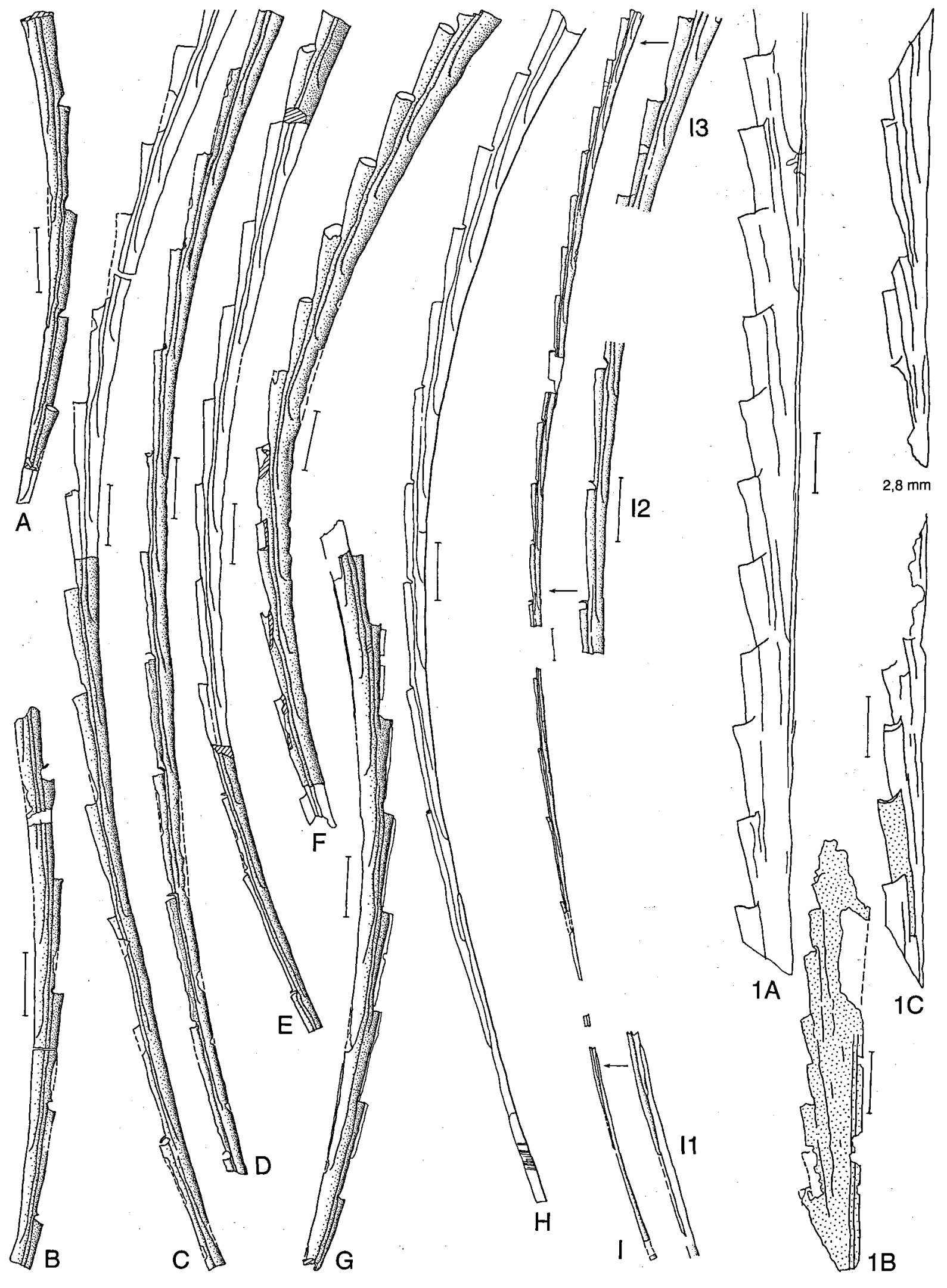


herein (Figs 11T, 12H). However, we failed to detect any ventral structures in flattened, but well preserved specimens. These structures are not present in the numerous specimens of $\mathrm{Ht}$. acinaces from Bornholm, some of which are in low or full relief. The ventral processes have not been discovered during the extensive $\mathrm{X}$-ray analysis of the pyritized specimens in relief from exposure 4 in Øle $\AA$ (Fig. 5). Some of them have been isolated and no other apertural structures except for the occasional small genicular flanges were shown. Similar observations were made by Štorch (1988) who described Ht. acinaces (i.e. Lg. aff. acinaces) from Bohemia which lacks the ventral processes. In this case their absence is difficult to ascribe to poor preservation, because specimens of Lagarograptus tenuis in the same type of preservation show well developed triangular ventral structures (Hutt 1968, Štorch 1988, text-fig. 5B-D). In addition numerous specimens of Ht. acinaces from Arctic Canada do not reveal these structures (Melchin 1995, personal communication). The present authors consider the development of the ventral processes as an important diagnostic feature of the Lagarograptus genus as it was postulated in the original description (Obut et al. 1968). For the above reason the species acinaces is excluded from Lagarograptus and assigned to Huttagraptus gen. nov.

The complete and well preserved material of $H t$. acinaces from $\emptyset$ le $\AA$ allows a detailed study of the morphology and proportions of rhabdosome, thecae and sicula, as well as of their variation in size. Hutt (1975) mentioned a variation in the position of the sicular apex in the specimens studied from the acinaces Biozone of Lake District. Original material from the Llandovery of Sweden (Törnquist 1899) as well as the Bornholm collections, previously described by Bjerreskov (1975) and those studied by the present authors also show this variation, though the sicular apex does not reach the th 1 aperture. In addition other characters such as the position for the origin of th1, the degree of overlap of th1 and the apical part of the sicula, the length of th1, as well as the degree of overlap of interthecal septa were found to be variable. The dorso-ventral width of the rhabdosome within the first 5-7 thecae is variable as is their length which results in variations in the thecal count in the first $10 \mathrm{~mm}$.

Huttagraptus billegravensis sp. nov.

Fig. 14

Derivation of name. - After the Billegrav-1 core.

Type. - Holotype, Fig. 14A, specimen 3, MGUH 24251 , the Billegrav-1 core, depth $16.75 \mathrm{~m}$.

Horizon. - Rhuddanian, the vesiculosus Biozone.

Material. - About 50 fragments of flattened rhab- dosomes, including extreme proximal parts with well preserved siculae; the Billegrav-1 core, depth 13.75$16.75 \mathrm{~m}$.

Diagnosis. - More than $30 \mathrm{~mm}$ long slender rhabdosome, often with broad dorsal curvature, minimum dorso-ventral width $0.25 \mathrm{~mm}$, maximum $0.8 \mathrm{~mm}$. Biform thecae, strongly geniculate proximally with flowing geniculum distally, widely spaced, numbering 6.5 proximally to $7.5-8.5$ distally in $10 \mathrm{~mm}$. Sicula more than $3.7 \mathrm{~mm}$ long.

Description. - The rhabdosome is more than $30 \mathrm{~mm}$ long, broadly dorsally curved and slowly increasing in width up to $0.5-0.6 \mathrm{~mm}$, a few fragments are 0.8 $\mathrm{mm}$ wide. Proximally the rhabdosome widens from $0.25-0.35 \mathrm{~mm}$ at th 1 to $0.35-0.5 \mathrm{~mm}$ at th5 and 0.40 $0.55 \mathrm{~mm}$ at th 10 . Distally the dorso-ventral width increases at about $0.1 \mathrm{~mm}$ within a distance of $25 \mathrm{~mm}$.

The thecae are geniculate, the feature is especially well expressed in the proximal part of the rhabdosome. The geniculate margin is thickened and some thecae show small genicular flanges. Apertural excavations occupy $1 / 2$ to $1 / 3$ of the dorso-ventral width. The straight apertures are horizontal, free ventral walls are almost parallel to the rhabdosome axis. The distal thecae show only a slight suggestion of geniculum and become almost pristiograptid-like. Their ventral walls are inclined at $8^{\circ}-10^{\circ}$ and apertures are slightly everted. However, the thecal morphology cannot be fully understood in specimens preserved flattened. The thecae overlap from $1 / 5$ to $1 / 4$ of their length, and they number $6.5-7.5$ in $10 \mathrm{~mm}$, in some cases 8.5 in $10 \mathrm{~mm}$ distally.

The sicula is $3.5-3.7 \mathrm{~mm}$ long and $0.24-0.26 \mathrm{~mm}$ wide at the aperture. Th1 is $2.2-2 \mathrm{~mm}$ long and originates about $1.5 \mathrm{~mm}$ above the sicula aperture. The sicula apex reaches the level of th1 aperture, the virgella is $2 \mathrm{~mm}$ long.

Remarks. - The species has close affinities with $H t$. praestrachani in general shape of the rhabdosome the morphology and proportions of thecae. It differs, however, in having longer sicula and more widely and evenly spaced thecae within both proximal and distal part of the rhabdosome. The free ventral walls of the distal thecae are more straight than those in $\mathrm{Ht}$. praestrachani. It can be distinguished from Huttagraptus gracilis (Hutt) in having more robust proximal end and more widely spaced thecae.

Fig. 13. A, C, D, Pristiograptus pristinus, Hutt, 1975, upper vesiculosus Biozone, Øle $\AA$, exposure $4 \mathrm{a}$; A, MGUH $24244 \times 30$; C, MGUH 24246; C1 enlargement of C; D, MGUH $24247 \times 20 ; \mathrm{B}, \mathrm{E}-\mathrm{G}$, Huttagraptus acinaces, upper vesiculosus Biozone, Øle $\AA$, exp. 4a; B, MGUH 24245 , proximal part, $\times 15 ; \mathrm{E}, \mathrm{MGUH} 24248 \times 10 ; \mathrm{F}, \mathrm{MGUH}$ $24249, \times 5$; G, MGUH 24250. 


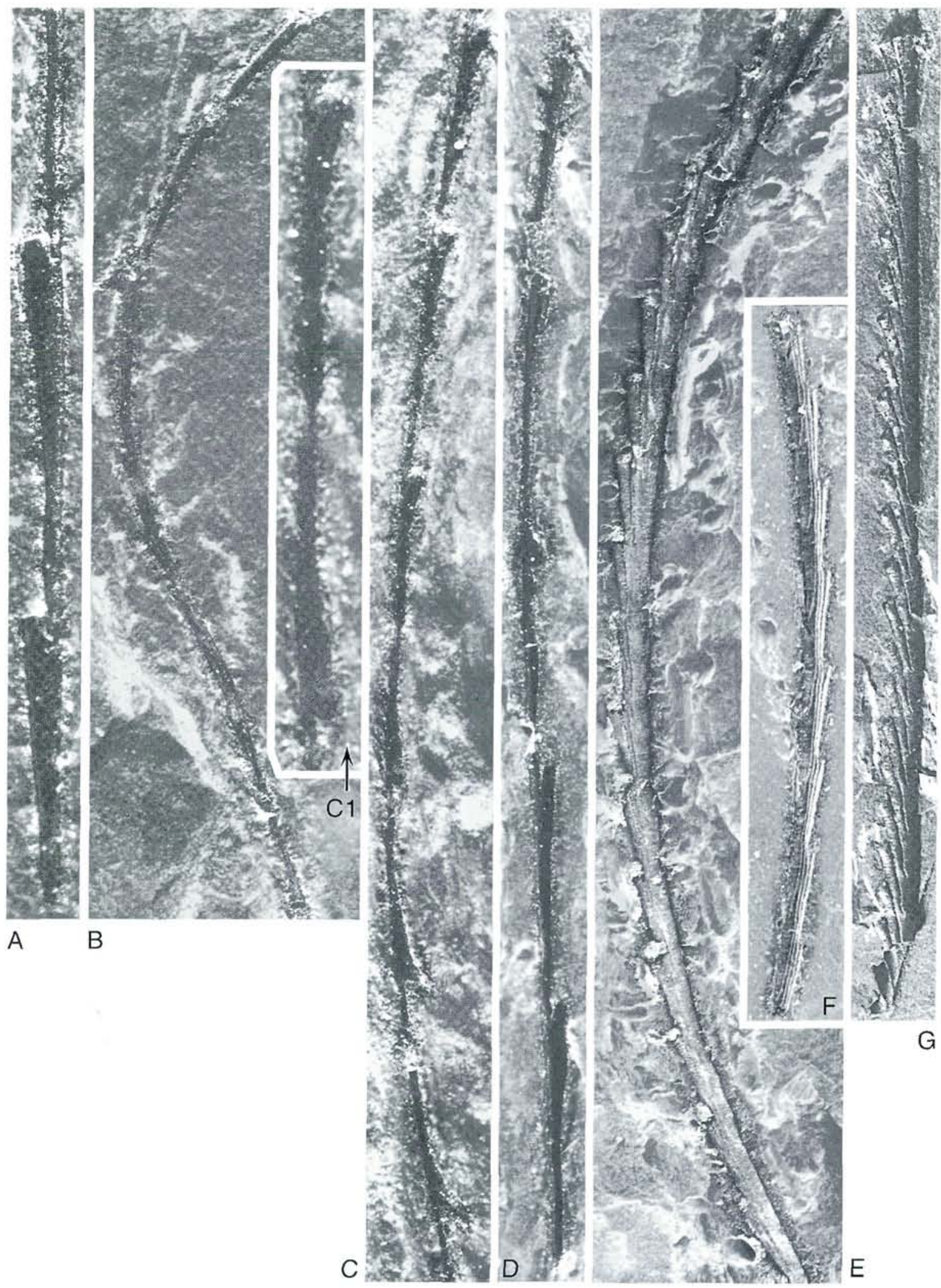

Koren' \& Bjerreskov: Early Llandovery monograptids from Bornholm and the southern Urals 
Huttagraptus incurvus sp. nov. Figs $15,16 \mathrm{E}-\mathrm{G}$ Derivation of name. - Latin "incurvus" meaning
curved.

Type. - Holotype, Figs 15C, 16F, MGUH 24269 specimen 1643-19, the southern Urals, Kos-Istek region, the Sakmara Formation, the vesiculosus Biozone.

Material. - 20 flattened specimens, some of which are well preserved from the same exposure as the holotype as well as from localities 477 and 1500/47 from the same region; the combined vesiculosuscyphus Biozones.

Diagnosis. - Rhabdosome sickle-like, dorsally curved, reaching $0.45 \mathrm{~mm}$ in the dorso-ventral width. Thecae are strongly geniculated, the feature which is accentuated by the well developed genicular flanges. Supragenicular walls are almost parallel to the rhabdosome axis. Small excavations are distinct. Thecae number 10 in 10 . Sicular apex does not reach the th1 aperture.

Description. - The rhabdosome is up to $10 \mathrm{~mm}$ long, strongly dorsally curved. The dorso-ventral width increases slowly from $0.25 \mathrm{~mm}$ to the maximum of 0.45 $\mathrm{mm}$ within th5-th7.

Uniformly geniculated thecae have pronounced genicular flanges overhanging the horizontal or slightly everted thecal apertures. Excavations are small compared to the thecal length. The supragenicular walls are almost straight and parallel to the dorsal wall. Thecae overlap $1 / 3$ to $1 / 2$ of their length and number 10 in $10 \mathrm{~mm}$.

Sicula is not complete in the subapertural portion, but its estimated length could be $2 \mathrm{~mm}$. The apex does not reach the th 1 aperture. Th1 is about $0.85 \mathrm{~mm}$ long.

Remarks. - From all known huttagraptids Ht. incurvus differs in having a sickle-like, fairly strong dorsally curved rhabdosome, well developed genicular flanges and the distinctly shorter th1. Compared to the other huttagraptids it has a shorter sicula, but this could be due to incomplete preservation of the metasicular part. Nevertheless, the above-mentioned differences are important, which make a generic assignment of this species to some extent arbitrary. The thecal style shows some distinct similarity with Monoclimacis, however the thecae have most probably genicular flanges and not dorsal hoods. The rhabdosomal size and thecal count of Ht. incurvus is similar to that of "Monoclimacis" lunata (Chen \& Lin) described from the same stratigraphical level in China (Chen \& Lin 1978). However, the Chinese species has very high position of the sicular apex, situated at about mid-way between th 2 and th 3 apertures.
Huttagraptus ninae sp. nov.

Figs 25A, C, D; 26A-C

Derivation of name. - In honour of the late Dr. Nina I. Leonenok, who was one of the first to study graptolite biostratigraphy in the southern Urals.

Type. - Holotype, figs 25C, 26B, MGUH 25353, exp. 1909 (spec. 1) from the vesiculosus-cyphus Biozone of the Kos-Istek region, the southern Urals.

Material. - 10 flattened fragments of the proximal part with sicula from the localities $671 / 8$ and 1909 , the same region and horizon as for holotype.

Diagnosis. - Broadly dorsally curved rhabdosome, 15 $\mathrm{mm}$ long and $0.4 \mathrm{~mm}$ wide. Geniculate thecae have well developed hoods, inclined supragenicular walls and slightly everted apertures. Long sicula and high position for the origin of th1.

Description. - Rhabdosome, $15 \mathrm{~mm}$ long, with an open dorsal curvature. The dorso-ventral width is $0.2 \mathrm{~mm}$ at th1, the maximum of $0.3-0.4 \mathrm{~mm}$ is attained between th4 and th5.

The strongly geniculate thecae have well developed genicular hoods, $0.1 \mathrm{~mm}$ long, completely overhanging the straight slightly everted apertures and slit-like excavations. Some of the thecae (Figs 25A, 26B; th3 and th4) show a tendency to an expansion of the ventral apertural margin. The most distal thecae are 1.35 $\mathrm{mm}$ long and $0.15 \mathrm{~mm}$ wide at the apertures. They overlap $1 / 3$ of their length and are inclined at $5^{\circ}-7^{\circ}$ to the rhabdosome axis. Thecal count can be estimated as 9 in $10 \mathrm{~mm}$.

Sicula is up to $3.7-3.8 \mathrm{~mm}$ long and approximately $0.2 \mathrm{~mm}$ wide at the aperture. Its apex is about the level of th1 aperture. Th1 is $1.7-1.8 \mathrm{~mm}$ long and originates at a distance of $1.6-1.7 \mathrm{~mm}$ above the sicular aperture.

Remarks. - The new species has longer genicular hoods compared with the other species of Huttagraptus. By the rhabdosomal shape and dimensions it is similar to Ht. strachani from which it can be distin-

Fig. 14. Huttagraptus billegravensis sp. nov.; fragments of rhabdosomes at different astogenetic stages, Billegrav1 core, vesiculosus Biozone; A, MGUH 24251, holotype, depth 16.75 m; B, MGUH 24252, depth 13.85 m; C, MGUH 24253, depth $16.75 \mathrm{~m}$; D, MGUH 24254, depth $16.25 \mathrm{~m}$; E, MGUH 24255, depth 16.25 m; F, MGUH 24256, depth $16.75 \mathrm{~m}$; G, MGUH 24257, depth $14.00 \mathrm{~m}$; H, MGUH 24258, depth 16.75; I, MGUH 24259, depth $14.35 \mathrm{~m}$; J, MGUH 24260, depth 16.75; K, MGUH 24261, depth 14.35 m; L, MGUH 24262, depth 15.05 m; M, MGUH 24263, $14.00 \mathrm{~m}$; N, MGUH 24264, depth $16.40-16.60 \mathrm{~m}$; O, MGUH 24265, depth 14.20 m; P, MGUH 24266. 


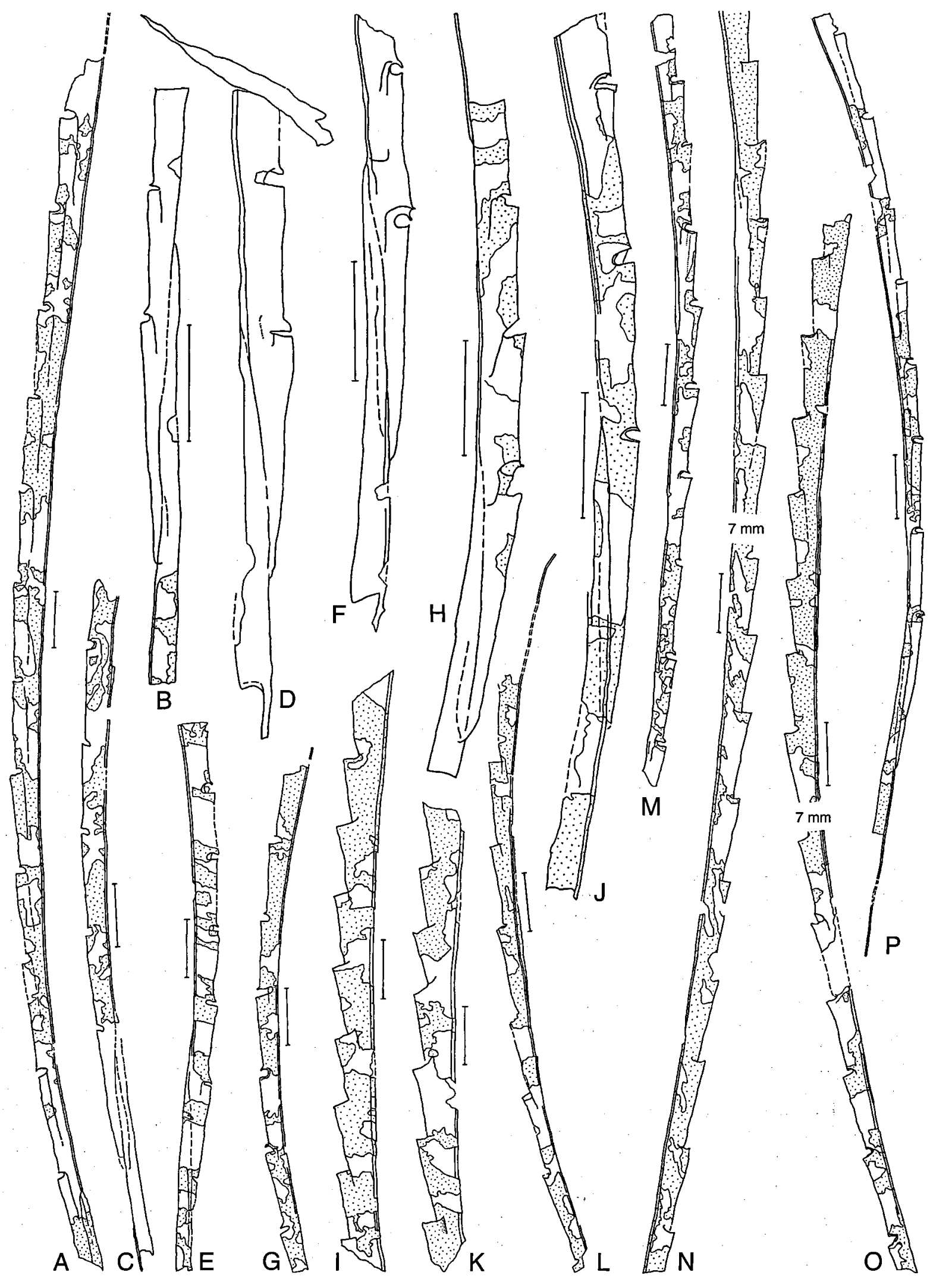



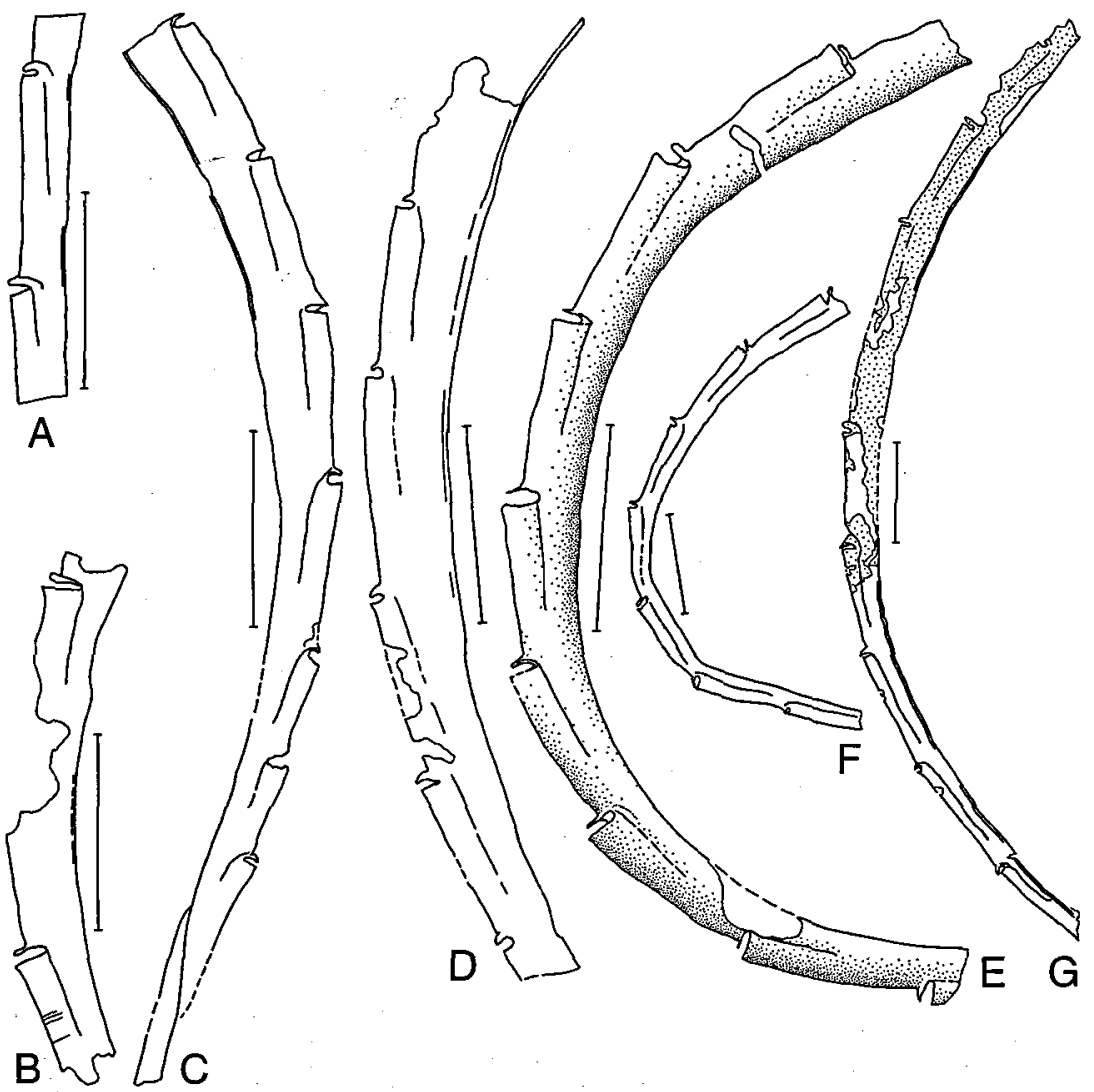

Fig. 15. Huttagraptus

incurvus sp. nov., vesiculosus Biozone, Kos-Istek region, the southern Urals. A, B, fragments showing thecal structures; A, MGUH 24267 exp. 1643; B, MGUH 24268, exp. 1643; C, MGUH 24269 , holotype, exp. 1643; D, MGUH 24270, exp. 1643; E, MGUH 24271, exp. 477; F, MGUH 24272, exp. 1500; G, MGUH 24273, exp. 1643.

guish by the more closely spaced and strongly overlapping thecae (Table 3).

Huttagraptus strachani (Hutt \& Rickards 1970) Figs 10J, K; 20A, B

1910 Monograptus incommodus Törnquist; Elles \& Wood, p. 406, pl. 40, fig. 1a-e, text-fig. 272ae.

1970 Monograptus strachani sp. nov.; Hutt \& Rickards, p. 75 , text-fig. $3 \mathrm{~g}-\mathrm{h}$.

1970 Atavograptus strachani (Hutt \& Rickards 1970 in Rickards 1970); p. 65-66, text-fig. 14, fig. 29 ; text-fig. 16, figs 14,15 ; text-fig. 18 , fig. 7 (see synonymy).

Type. - Holotype figured by Elles \& Wood 1911, textfig. 272a; SM A21030; from the Birkhill Shales, cyphus Biozone, Dobb's Linn, Scotland.

Material. - 4 flattened, but well preserved fragments of proximal and mesial parts of the rhabdosome from exposure $671 / 8$, Kos-Istek region, the southern Urals, cyphus Biozone.
Description. - The rhabdosome is $20 \mathrm{~mm}$ long with a gentle dorsal curvature throughout its length. The dorso-ventral width increases slowly from $0.3 \mathrm{~mm}$ at th 1 to $0.5 \mathrm{~mm}$ of about $20 \mathrm{~mm}$ from the sicula.

The distinctly geniculate thecae predominate in astogeny. They have semicircular excavations, almost horizontal apertures and well developed genicular rims; sometimes there is a suggestion of genicular flanges. Towards the distal end geniculation decreases and most thecae have a small flowing geniculum. The supragenicular walls are almost parallel to the rhabdosome axis in the proximal part and show a tendency to be slightly inclined distally. Thecal overlap in-

Fig. 16. A-E, Huttagraptus praestrachani (Hutt \& Rickards, 1977), vesiculosus Biozone. A, MGUH 24274; B, MGUH 24275; C, MGUH 24276; E, MGUH 24278; A-C, E, distal fragments; D, MGUH 24278 proximal and distal fragments, probably belonging to the same colony; exp. $671 / 8$ and $671 / 1$, Kara-Dzhilga, the southern Urals. All $\times$ 10; E-G: Huttagraptus incurvus sp. nov., vesiculosus Biozone; E, MGUH 24278; F, holotype, MGUH 24269, exp. 1643, Kos-Istek region, southern Urals; G, MGUH 24279 exp. 477 , the same region; $G 1$, detail of the thecal structure; F, G, × 20; G1, $\times 40$. 


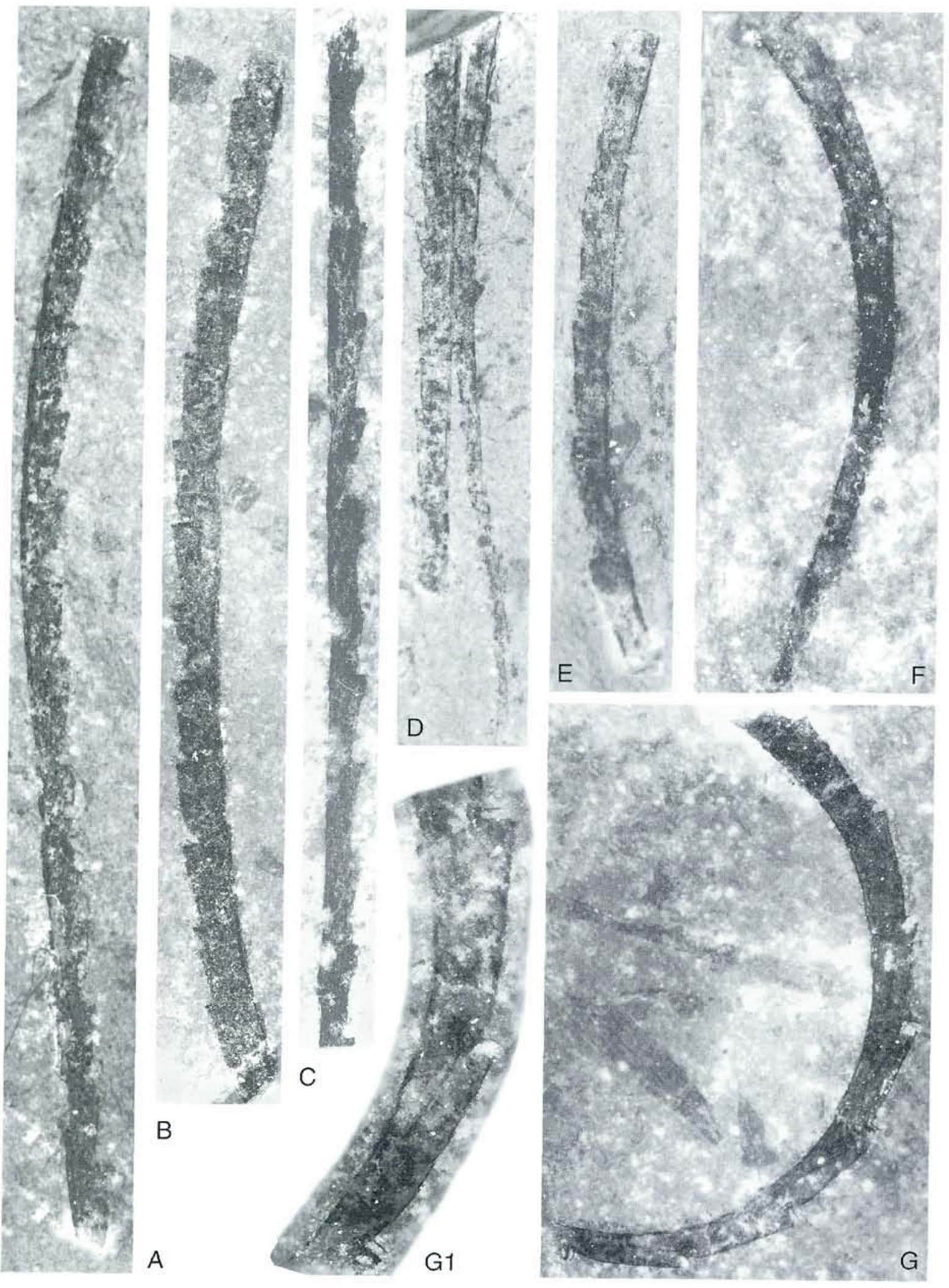


creases from $1 / 5$ to more than $1 / 3$ distally. Thecal count is $7-8$ in $10 \mathrm{~mm}$.

The sicula is more than $3 \mathrm{~mm}$ long, and $0.25 \mathrm{~mm}$ wide at the aperture. The virgella is usually uncomplete. Th1, 1.6-1.7 mm long, originates at a distance $1.3 \mathrm{~mm}$ above the sicular aperture. The sicular apex is slightly above the th1 aperture.

Remarks. - The dimensions and thecal structure of these specimens agree well with the previous descriptions of Ht. strachani. The species can be distinguished from $H t$. praestrachani by the more widely set proximal thecae and more constantly developed genicular rims and small flanges.

\section{Huttagraptus sp. 1}

Fig. 17F-K

Material. - 10 flattened fragments without sicula; the Billegrav-1 core, depth $16.75-18.15 \mathrm{~m}$, vesiculosus Biozone.

Description. - The rhabdosome is broadly dorsally curved with a tendency to be less so distally. The longest fragments reach about $20 \mathrm{~mm}$ and have 20-22 thecae, although the fragmentary material suggests that the rhabdosome could have been longer. No proximal ends with sicula have been seen. The dorso-ventral width increases from $0.2 \mathrm{~mm}$ to $0.6-0.7 \mathrm{~mm}$.

The thecae are geniculate with straight supragenicular walls inclined at $2^{\circ}-5^{\circ}$ to the rhabdosomal axis. Horizontal apertures open into slit-like excavations occupying $1 / 3$ to $1 / 2$ of the dorso-ventral width. Some thecae show thickened genicular rims. Distal thecae appear to become less geniculate and almost pristiograptid-like with the ventral walls inclined at $6^{\circ}-8^{\circ}$. The thecal length and overlap could not be measured due to the heavily carbonized nature of the periderm. Thecae number $9-10$ in $10 \mathrm{~mm}$, in a few specimens up to 5.5 in $5 \mathrm{~mm}$ proximally and $8.5-9$ in $10 \mathrm{~mm}$ in the most distal fragments.

Remarks. - The present form shows typical huttagraptid affinities in having distinctly geniculate thecae with genicular rims and excavations. However, the proximal end with sicula has not been found. Huttagraptus sp. 1 appears in the core slightly earlier than other species of Huttagraptus. It differs from $\mathrm{Ht}$. billegravensis $\mathrm{sp}$. nov. in having more strongly geniculate and closely set thecae and can be distinguished from $\mathrm{Ht}$. gracilis by the more pronounced geniculum throughout the whole rhabdosome length. Compared with $H t$. praestrachani the present form has more closely spaced thecae with no tendency to form genicular rims and it attains its maximum dorso-ventral width more quickly.

The rhabdosomal shape and size as well as the the- cal outline in Huttagraptus sp. 1 are almost identical to those in the uniserial part of $D i$. elongatus. In the Billegrav-1 core both forms occur together at a depth of 16.75-17.80 m, which makes specific assignment of many specimens difficult dealing with fragmentary material (Fig. 17). The only observed differences between the two forms are the less strongly curved rhabdosome and slightly more rapid increase in the dorso-ventral width in the uniserial portion of $D i$. elongatus. The difference in number of thecae, which is $9-10$ in $10 \mathrm{~mm}$ in Huttagraptus sp. 1 and 7.5-9 in the uniserial portion of D. elongatus does not seem to be significant.

\section{Huttagraptus sp. 2}

Fig. 18

Material. - The fragmentary material comprises 15 flattened fragments of the mesial and distal parts of rhabdosomes from the Billegrav-1 core, depth 12.00$15.80 \mathrm{~m}$, vesiculosus Biozone.

Description. - The rhabdosome is more than $50 \mathrm{~mm}$ long, slender and broadly dorsally curved becoming almost straight distally. The slowly increasing dorsoventral width is $0.24-0.26 \mathrm{~mm}$ at th1, $0.24-0.27 \mathrm{~mm}$ at th $2,0.3 \mathrm{~mm}$ at th $3,0.33 \mathrm{~mm}$ at th 4 and $0.35 \mathrm{~mm}$ at th5. The rhabdosome widens generally to $0.1-0.2 \mathrm{~mm}$ at a distance of about $20 \mathrm{~mm}$ and reaches $0.6-0,7 \mathrm{~mm}$ in the most distal fragments.

The proximal 10 to 15 thecae are strongly geniculate, with well developed genicular rims, and their supragenicular walls are almost parallel to the dorsal side of the rhabdosome. A geniculum is less pronounced in the distal thecae, which have slightly everted apertures and ventral walls inclined at $5^{\circ}-8^{\circ}$. The distal thecae are 2.1-2.2 mm long and 0.3-0.4 $\mathrm{mm}$ wide. They overlap at about $1 / 4$ of their length and number $6.5-7$ in $10 \mathrm{~mm}$ proximally and 5.5-6.5 in $10 \mathrm{~mm}$ distally.

Only two short fragments have a sicula and a few proximal thecae. The sicula is $2.1-2.2 \mathrm{~mm}$ long and

Fig. 17. A-E, Dimorphograptus elongatus Törnquist, 1899, lower part of the vesiculosus Biozone, Billegrav-1 core; A, MGUH 24280, a juvenile rhabdosome with th2 starting to grow, depth 17.10; D, MGUH 24283, a fragment of a uniserial part of a rhabdosome with sicula showing the high position for the th1 origin, depth $17.10 \mathrm{~m}$; B, C, E, adult uni-biserial rhabdosomes; B, MGUH 24281, depth 17.20 m; C, MGUH 24282, depth 17.30 m; E, MGUH 24284, depth $17.20 \mathrm{~m} ; \mathrm{F}-\mathrm{K}$, Huttagraptus sp. 1, fragments of different parts of rhabdosomes with no sicula, lower vesiculosus Biozone, Billegrav-1 core; F, MGUH 24285, depth $18.15 \mathrm{~m}$; G, MGUH 24286, depth $16.75 \mathrm{~m}$; H, MGUH 24287, depth 17.95 m; I, MGUH 24288, depth 17.10 m; J, MGUH 24289, depth 17.10 m; K, MGUH 24290. 

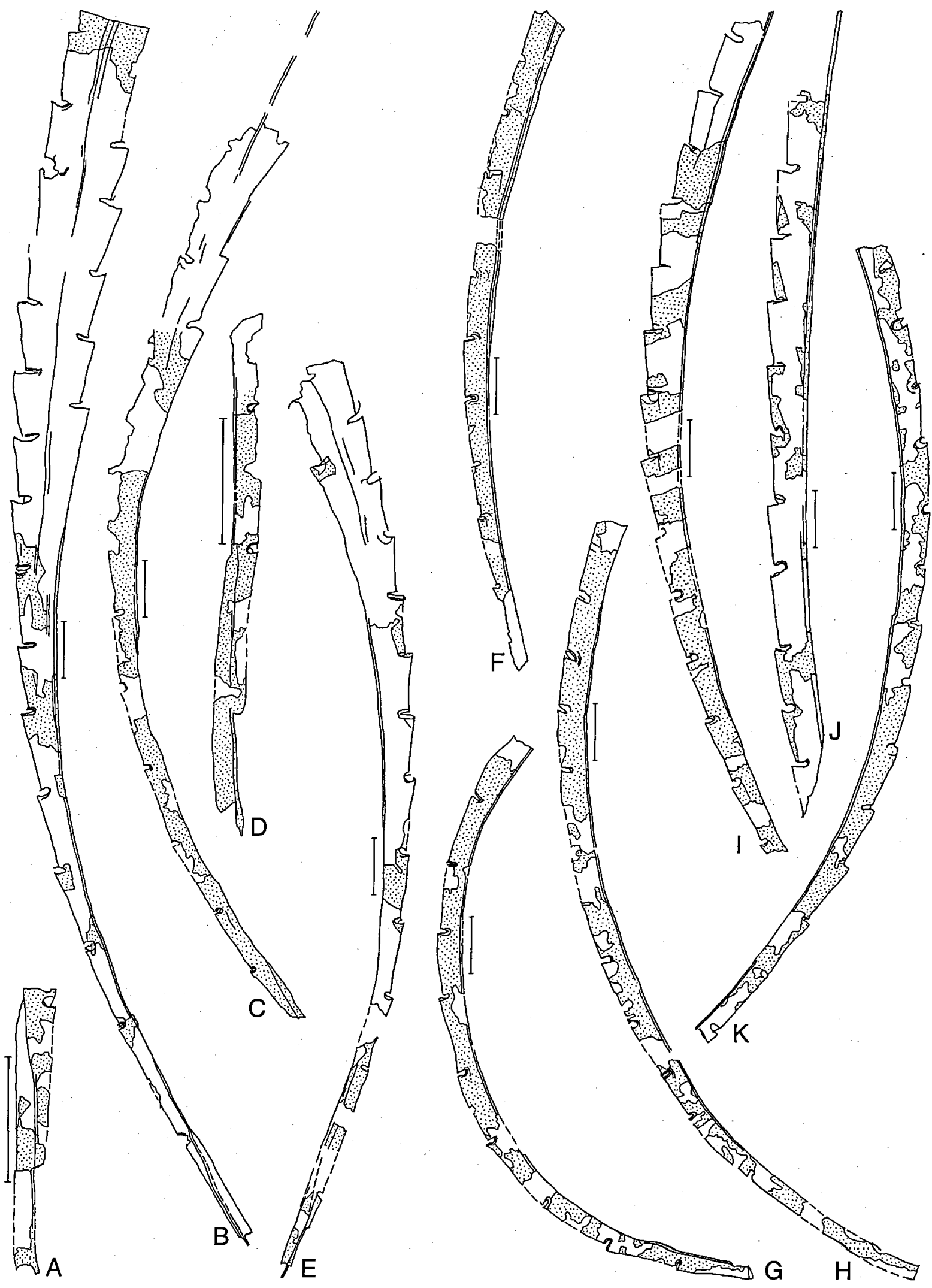
$0.3 \mathrm{~mm}$ wide at the aperture. The apex reaches the level at the base of the th 1 and th 2 septum, which is well below the th1 aperture. The virgella is incomplete. Th1, about $2 \mathrm{~mm}$ long, originates $0.6 \mathrm{~mm}$ above the sicular aperture.

Remarks. - The broad dorsal curvature, the long, slender rhabdosome and geniculate proximal and mesial thecae are the main features which make an assignment of the present form to Huttagraptus. Huttagraptus sp. 2 can be distinguished from the other species of the genus in having either very widely set thecae (contrary to $\mathrm{Ht}$. gracilis) or more slender proximal end (as compared with Ht. billegravensis). The sicula seen in a few short specimens is not more than $2 \mathrm{~mm}$ long with thl bud situated close to its aperture $(0.55$ $\mathrm{mm}$ ), both features are not typical for the huttagraptids studied. However, the proximal fragments found may not belong to the same species, thus the present form is described in open nomenclature until more complete material is found.

\section{Huttagraptus sp. 3}

Fig. 25E

Material. - One flattened specimen from exp. $4 a$ in $\emptyset$ le $\AA$, Bornholm, the upper part of vesiculosus Biozone.

Description. - The rhabdosome, $18 \mathrm{~mm}$ long, with an open dorsal curvature. The dorso-ventral width slowly increases from $0.28 \mathrm{~mm}$ at th1 to $0.4 \mathrm{~mm}$ at th5 and the maximum of $0.5-0.55 \mathrm{~mm}$ is attained at th10.

The geniculate thecae have well developed genicular hoods, $0.10-0.15 \mathrm{~mm}$ long. They overhang horizontal or slightly everted apertures and shallow excavations. The proximal thecae are strongly elongated and overlap approximately $1 / 5$ of their length. The distal thecae, $1.8-2 \mathrm{~mm}$ long, overlap $1 / 3$ of their length. The angle of inclination of the ventral walls increases from $5^{\circ}-6^{\circ}$ proximally to $10^{\circ}-12^{\circ}$ distally. The thecal count is 6-7 in the first $10 \mathrm{~mm}$ and it increases distally to 8 in $10 \mathrm{~mm}$.

Sicula is approximately $2 \mathrm{~mm}$ long and $0.2 \mathrm{~mm}$ wide at the aperture. Th1 originates at about $1.0 \mathrm{~mm}$ above the sicular aperture and attains $2 \mathrm{~mm}$ in length. The sicular apex reaches only a half way of the thl length.

Remarks. - The dorsally curved rhabdosome with elongated and geniculated thecae, genicular rims or hoods is characteristic of several huttagraptid species described herein from the vesiculosus Biozone. The present form has more strongly developed genicular hoods, which are of the size, typical for lagarograptids. However, it has no indication of the ventral apertural processes. From Ht. ninae sp. nov. it differs in having shorter sicula, more widely spaced thecae and lower position of sicular apex. The preservation of the sin- gle specimen is not enough to describe it as a new species.

\section{Pristiograptus Jaekel 1889}

Type species. - Pristiograptus frequens Jaekel, 1889, by the original designation.

\section{"Pristiograptus" pristinus Hutt 1975}

Figs 5C, 13A-D, 19

1975. Pristiograptus fragilis pristinus subsp. nov.; Hutt, p. 60, text-fig. 14, figs 8-9.

Type. - Holotype figured by Hutt 1975 SM A83992; text-fig. 14, fig. 8; SM A83992; acinaces Biozone of Yewdale Beck, Lake District.

Material. - More than 100 specimens in different state of preservation, flattened, in low relief and in 3-D from exp. 4 (Bjerreskov 1975) and exp. 4a in Øle $\AA$; about 50 flattened fragments from the Billegrav-1 core, depth 3.40-14.35 m, vesiculosus Biozone.

Description. - Fragments of the extremely slender flexed rhabdosome are more than $30 \mathrm{~mm}$ long with a dorso-ventral width of $0.15-0.23 \mathrm{~mm}$ at the thecal aperture.

The thecae are $2 \mathrm{~mm}$ long, overlapping each other at about $1 / 10-1 / 12$ of their length. They mostly consist of slowly widening prothecae, the metathecae being exceptionally short (no more than $0.1-0.16 \mathrm{~mm}$ ) and slightly flaring. The apertures are straight and distinctly everted. The width at the base of metatheca is $0.03 \mathrm{~mm}$ in specimens in 3D and $0.05-0.08 \mathrm{~mm}$ in flattened rhabdosomes. The free ventral walls are straight, $1.65-1.8 \mathrm{~mm}$ long, and inclined at $2^{\circ}-3^{\circ}$ to the rhabdosome axis. The thecal count is 6 in $10 \mathrm{~mm}$ proximally to $5.5-6$ in $10 \mathrm{~mm}$ distally.

One fragment of the extreme proximal part of the rhabdosome have at least partly preserved metasicula, $0.9 \mathrm{~mm}$ long (Fig. 19A). Th1 possibly originates at a

Fig. 18. Huttagraptus sp. 2, fragments of rhabdosomes at different astogenetic stages; vesiculosus Biozone, Billegrav-1 core. A, MGUH 24291, depth 15.10 m; B, MGUH 24292, depth $15.05 \mathrm{~m}$; C, MGUH 24293, $15.05 \mathrm{~m}$; D; MGUH 24294, depth $15.05 \mathrm{~m}$; E, MGUH 24295, depth $15.70 \mathrm{~m}$; F, MGUH 24296, depth 14.70-14.75 m; G, MGUH 24297, depth 15.10 m; H, MGUH 24298, depth $15.20 \mathrm{~m}$; I, MGUH 24299, depth $15.80 \mathrm{~m}$; J, MGUH 24300 , depth $15.05 \mathrm{~m}$; K, MGUH 24301, depth 5.67-5.90 m; L, MGUH 24302, depth 15.34 m; M, MGUH 24303, depth 8.47-8.65 m; N, MGUH 24304, depth 9.49-9.58 m; O, MGUH 24305, depth 15.80 m; P, MGUH 24306, depth 9.65-9.75 m. 


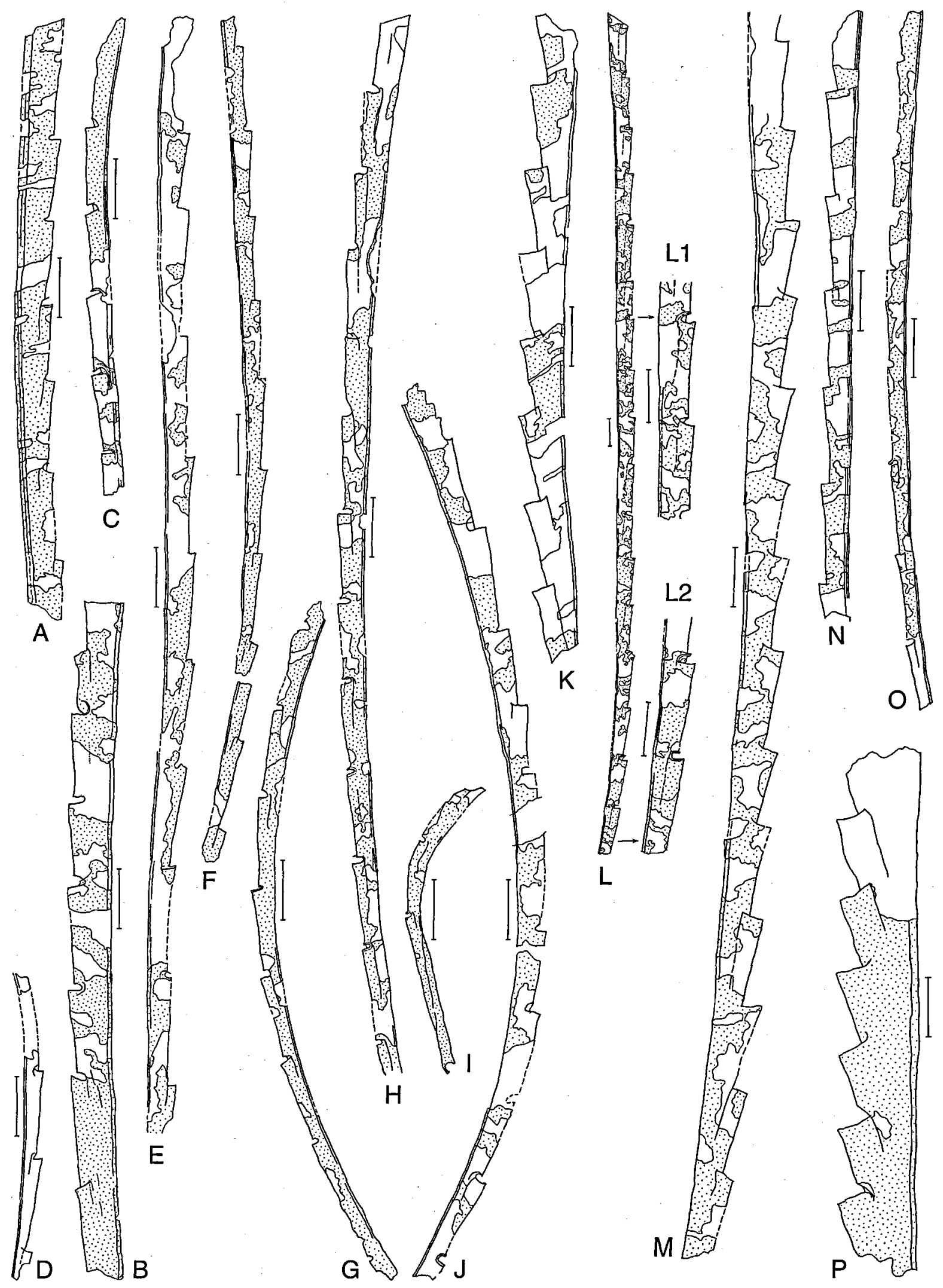


distance of $0.8 \mathrm{~mm}$ from the aperture of the sicula and attains $1.9 \mathrm{~mm}$ in length.

In the material studied several bipolar rhabdosomes have been found (Figs 5C, 19K, L), which shows a distinct example of formation of a regeneration branch, $25 \mathrm{~mm}$ long, growing in the opposite direction to that of the primary branch. The regenerating branch, called pseudocladium (Urbanek 1963, 1973), is $25 \mathrm{~mm}$ long, shows some irregularities in the thecal formation at the level of th4 and th5. Metatheca of th4 is abnormally long contrary to th5, which is very short, and attains a comparatively large width at the aperture. This case could be interpreted as regeneration after damage at the level of th5.

Remarks. - The present specimens agree well with "Pr." fragilis pristinus, known from the Lake District (Hutt 1975). Originally this form was described as a subspecies, although the distinct thecal shape and proportions justify full species rank. In Bornholm "Pr." pristinus occurs within the upper part of the vesiculosus Biozone which is much earlier than any other pristiograptid species. In some beds it is found in masses as shown by the X-Ray investigations (Fig. 5C). Generic assignation of "Pr." pristinus is uncertain as it differs from the oldest known Aeronian representatives of Pristiograptus (Pr. concinnus) in having: (1) strongly elongated thecae, (2) extremely short metathecae with a tendency to some isolation in its subapertural part and (2) the high position of the th1 bud. However, with a better knowledge of the possible derivation of "Pr." pristinus, the species could be considered as the probable progenitor of the Silurian pristiograptid stock.

\section{Genus Pribylograptus Obut \& Sobolevskaya 1966}

Type species. - Monograptus incommodus Törnquist, 1899 ; by original designation.

Pribylograptus incommodus (Törnquist, 1899)

Figs 20C-D, 21

1899 Monograptus incommodus n. sp.; Törnquist, p. 11, pl. 2, figs $1-5$.

1966 Pribylograptus incommodus (Törnquist); Obut \& Sobolevskaya, p. 34, pl. 6, fig. 9, ?text-fig. 25.

1968 Monograptus incommodus Törnquist; Rickards \& Rushton, p. 272, fig. 4 a-d.

1968 Pribylograptus incommodus (Törnquist); Obut, Sobolevskaya (\& Merkurjeva), p. 88, pl. 16, fig. 8 , pl. 17, figs 4-5, non figs $1-3$.

1970 Monograptus incommodus Törnquist; Hutt \& Rickards, p. 69, text-fig. 2c.

1975 Pribylograptus incommodus (Törnquist); Hutt, p. $71-72$, pl. 16, 6, 8, 10; text-fig. 16, fig. 6 .
1975 Monograptus incommodus Törnquist; Bjerreskov, p. 50, fig. $16 \mathrm{~F}$, pl. 7 , D.

Type. - Lectotype figured by Törnquist $1899, \mathrm{pl} .2$, fig. 1; LO 1456t; by subsequent designation by Prribyl 1948 , p. 79; refigured Hutt \& Rickards 1970, text-fig. 2c. Figured herein, fig. 21A.

Material. - More than 100 specimens which are fragments of mesial and distal parts of rhabdosomes, preserved as flattened, in low and full relief, the Billegrav1 core, depth 3.40-12.80 $\mathrm{m}$ and in exp. 4, 4a in Øle $\AA$; upper vesiculosus Biozone; 6 flattened specimens from the localities 1909-2, 671/8-308, the combined vesiculosus-cyphus Biozone, Kara-Dzhilga, Kos-Istek region; 5 fragments, consisting of several thecae isolated from limestones, exposure 1011, Orenburg district, River Dergaish, the Masovo Village, the southern Urals, vesiculosus Biozone.

Description. - Rhabdosome flexed, more than $30 \mathrm{~mm}$ long, with the maximum dorso-ventral width varying from $0.5 \mathrm{~mm}$ to $0.65 \mathrm{~mm}$. The proximal end with sicula has not been found.

The most distal thecae are 2-3 mm long and 0.15$0.25 \mathrm{~mm}$ wide in the metathecal part. Their angle of inclination is less than $10^{\circ}$ and the overlap does not reach $1 / 2$ of the thecal length. The ventral and dorsal walls of the thecae are parallel to the rhabdosome axis, except for a geniculum with well pronounced genicular rim. The apertures are transversally expanded and elaborated in the form of a pair of lateral lappets, 0.2 $\mathrm{mm}$ long and $0.18 \mathrm{~mm}$ high. The lappets are adpressed to the dorso-lateral sides of the rhabdosome. Thecae number $7-8$ in $10 \mathrm{~mm}$.

Remarks. - The type material of Prb. incommodus has been studied and refigured herein (Fig. 21A). The thecal morphology and dimensions leave no doubt that the fragmentary rhabdosomes, found in Bornholm, and in the southern Urals belong to Prb. incommodus.

Fig. 19. "Pristiograptus" pristinus Hutt, 1975, upper vesiculosus Biozone; A1-A3, fragments of a pyritized specimen with partly preserved sicula, MGUH 24307, exp. 4; B, C, D, short fragments of pyritized specimens, showing thecal structure, exp. 4a; B, MGUH 24308; C, MGUH 24244; D, MGUH 24309; E, F, G, fragments of pyritized specimens, exp. 4a; E, MGUH 24310; F, MGUH 24311; G, MGUH 24312; H, I, fragments of flattened rhabdosomes, Billegrav-1 core, depth $14.35 \mathrm{~m}$; H, MGUH 24313; I, MGUH 24314; J, MGUH 24315, exp. 4a; K, MGUH 24316, fragment of a bipolar thabdosome, Billegrav-1 core, depth 14.35 m; L, MGUH 24317, a pyritized rhabdosome showing primary and regenerating branches, exp. $4 \mathrm{a} ; \mathrm{L} 1$, detail showing the place of regeneration; L2, detail showing irregularities in thecae formation; $\mathrm{L3}$, details of thecal structure; M, MGUH 24318, Billegrav-1 core, depth 4.75 m. 


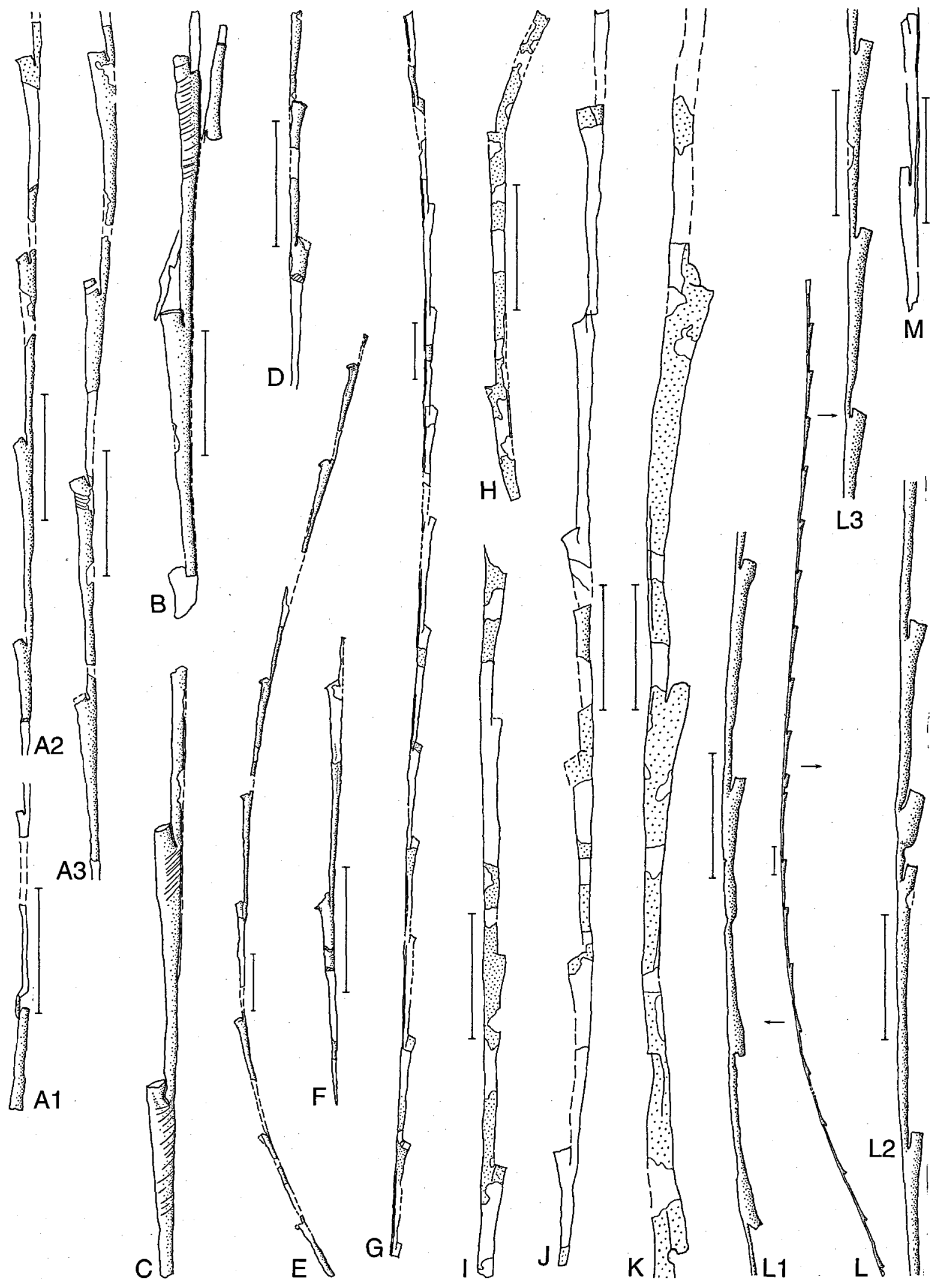




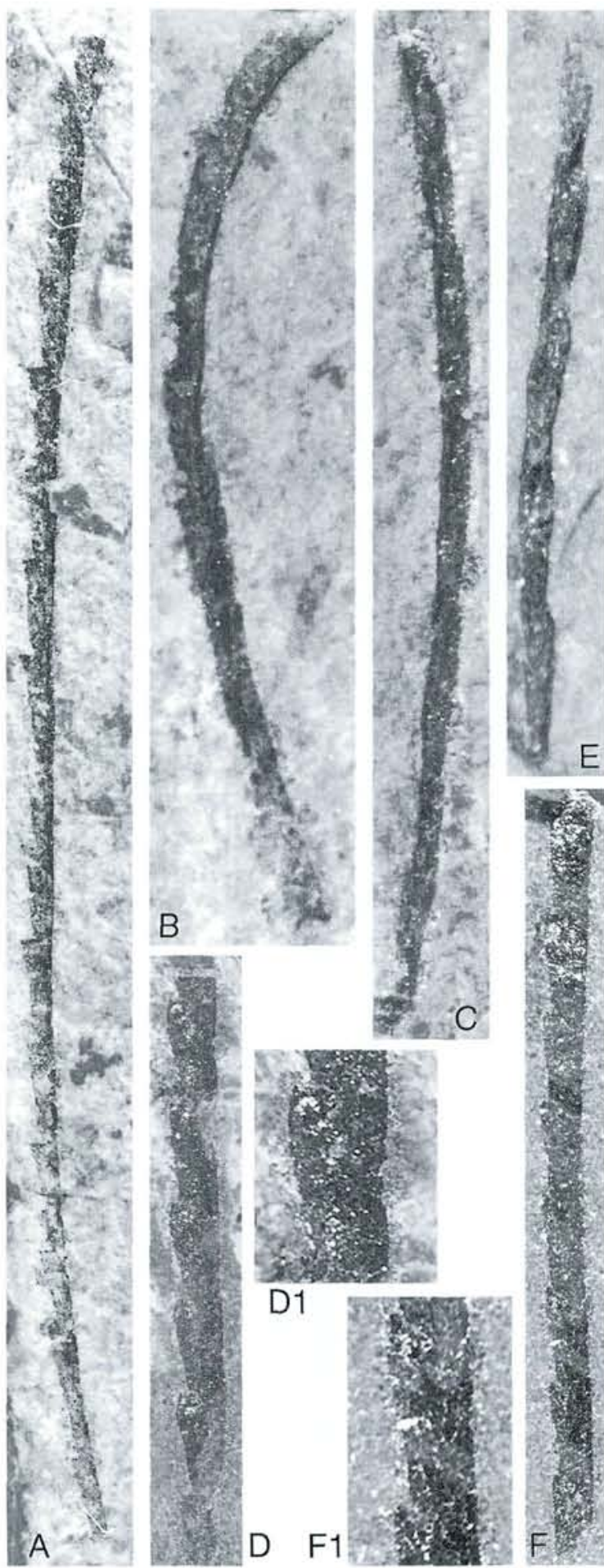

From Prb. sandersoni the present species differs in having stronger introversion of thecal apertures with well developed lateral structures. However, this feature is not always evident in the flattened specimens.

Pribylograptus sandersoni (Lapworth, 1876)

Figs 20E, F; 22A-G

1876 Monograptus sandersoni sp. nov.; Lapworth, p. 310 , pl. 11, fig. 2a-e.

1968 Pribylograptus sandersoni (Lapworth); Obut, Sobolevskaya (\& Merkurjeva), p. 89-90, pl. 17, figs $6, ? 7$, pl. 18, figs $1,3, ? 2$.

1970 Pribylograptus sandersoni (Lapworth); Rickards, p. 66-67, text-fig. 14, fig. 25.

1975 Monograptus sandersoni Lapworth; Bjerreskov, p. 49-50, fig. 16D.

Type. - Lectotype figured by Lapworth 1876, pl. 11, fig. 2a; subsequently designated by Přibyl 1948, p. 79; from the Birkhill Shales, Dobbs Linn, Scotland.

Material. - 12 poorly preserved flattened fragments, the Billegrav- 1 core, depth $13.80 \mathrm{~m}-15.00 \mathrm{~m} ; 10$ fragments of flattened rhabdosomes including the extreme proximal ends with sicula from the localities 399/4 $2,671 / 1-400,671 / 8-280,671 / 8-288,671 / 8-308$; the Kos-Istek region, the southern Urals, vesiculosus Biozone.

Description. - The rhabdosome fragments observed in the present material are $10-15 \mathrm{~mm}$ long and usually almost straight. The dorso-ventral width measured at th1 aperture is $0.14-0.16 \mathrm{~mm}$, it reaches 0.6 $\mathrm{mm}$ in the most distal fragments.

The thecae have straight or slightly sigmoidally curved ventral walls, inclined at $5^{\circ}-10^{\circ}$ to the rhabdosome axis. Their apertures are introverted and have

Fig. 20. A-B: Huttagraptus strachani (Hutt \& Rickards, 1970), Kara-Dzhilga, the southern Urals, cyphus Biozone; A, MGUH 24319, a distal fragment, exp. 671/8a, × 10; B, MGUH 24320, a proximal fragment with sicula preserved, exp. 671/8, × 20; C, D: Pribylograptus incommodus (Törnquist, 1899); C, MGUH 24321, a proximal fragment with sicula, preserved, MGUH 24321, exp. 1643, combined vesiculosus-cyphus Biozone, Kos-Istek region, the southern Urals, $\times 20$; D, MGUH 24322, a distal fragment, the Billegrav-1 core, vesiculosus Biozone, $\times 10$; D1, detail of the thecal structure of the same specimen, $\times 20 ; \mathrm{E}, \mathrm{F}$, Pribylograptus sandersoni (Lapworth 1876); E, MGUH 24323, exp. 399-4, combined vesiculosus-cyphus Biozone, Kos-Istek region, the southern Urals, $\times 20$; F, MGUH 24324 , vesiculosus Biozone, the Billegrav-1 core, $\times 10$; $F 1$ detail of the thecal structure of the same specimen, $x$ 20 . 
a tendency to be adpressed to the lateral side of the pansion. Thecal overlap increases from $1 / 8$ seen in the extreme proximal end to $1 / 3$ in the most distal fragments, where thecae are 1.5-1.6 mm long. Thecae number $6-6,5$ in $10 \mathrm{~mm}$ proximally and $7.5-8.5$ in 10

Sicula is $1.8-2.0 \mathrm{~mm}$ long and $0.1 \mathrm{~mm}$ wide at the aperture with the apex reaching about half of the th1 length. Thl originates at approximately $1.0 \mathrm{~mm}$ above the sicular aperture and attains the length of $2.00 \mathrm{~mm}$.

Remarks. - In spite of the fragmentary material the diagnostic features of Prb. sandersoni, such as the introversion and adpression of slightly expanded thecal apertures, are well seen in the material studied. For the first time the thread-like extreme proximal end with sicula and widely spaced thecae has been observed in the Uralian collection from the vesiculosus Biozone. Prb. sandersoni can be distinguished from the succeeding Prb. incommodus in having simpler apertural structures with no signs of lateral lappets.

?Pribylograptus sp.

Fig. 22K-M

Material. - 1 specimen in 3D from the exp. 4a (sp. 884 ) in Øle $\AA$, Bornholm; 3 fragments of flattened rhabdosome including the extreme proximal part with sicula from the localities 399/4-2 and 1643-37, KosIstek region, the southern Urals, the vesiculosus Biozone.

Description. - Rhabdosome is more than $40 \mathrm{~mm}$ long with the dorso-lateral width being $0.15 \mathrm{~mm}$ at th1, $0.17 \mathrm{~mm}$ at th5 and $0.25-0.3 \mathrm{~mm}$ in the most distal fragments.

Thecae, up to $2.5 \mathrm{~mm}$ long, are strongly geniculate with distinctive rims and small excavations. Their apertures show a slight tendency to introversion. The supragenicular walls are straight, sometimes slightly convex in the subapertural part. Thecae overlap about $1 / 2$ of their length and number $8-9$ in $10 \mathrm{~mm}$.

Fig. 21. Pribylograptus incommodus (Törnquist, 1899); A, holotype, fragment showing thecal structure, LO 14567 , Törnquist, 1899, pl. II, fig. 1; B, LO 14571, Törnquist, 1899 , pl. II, fig. 2, details of thecal structure; C, LO 1460T, Törnquist, 1899 , pl. II, fig. 5, distal fragment; D, MGUH 24325 , a distal fragment, upper part of vesiculosus Biozone, depth 8.47-8.66 m; E, F, fragments showing proximal thecae structure; E, MGUH 24326, exp. 671/8-308, KaraDzhilga; F, MGUH 24327, exp. 1909/2, Kos-Istek region; combined vesiculosus-cyphus Biozone, the southern Urals; $\mathrm{G}, \mathrm{H}$, fragments showing distal thecae structure; $\mathrm{G}, \mathrm{MGUH}$ 24328, exp. 671/8-280, Kara-Dzhilga; H, MGUH 24329, Billegrav-1 core, 1 , depth $8.80-8.95 \mathrm{~m}$. rhabdosome. Distal thecae show slight apertural ex$\mathrm{mm}$ distally.
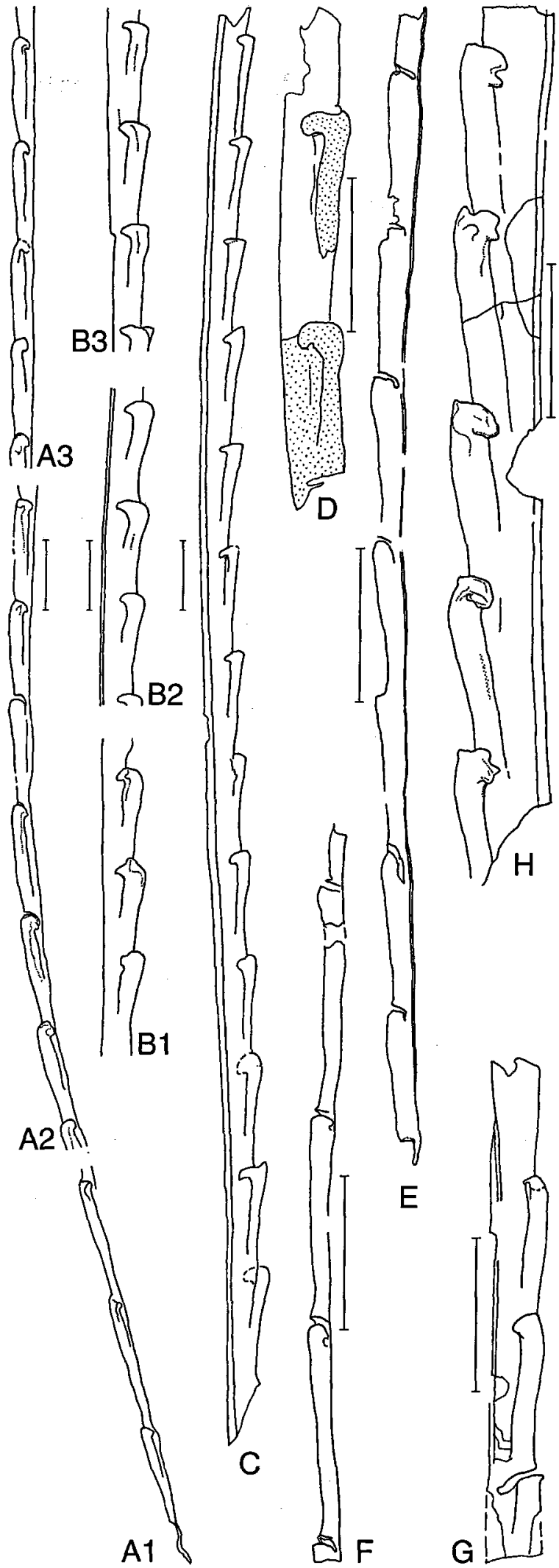

Koren' \& Bjerreskov: Early Llandovery monograptids from Bornholm and the southern Urals 


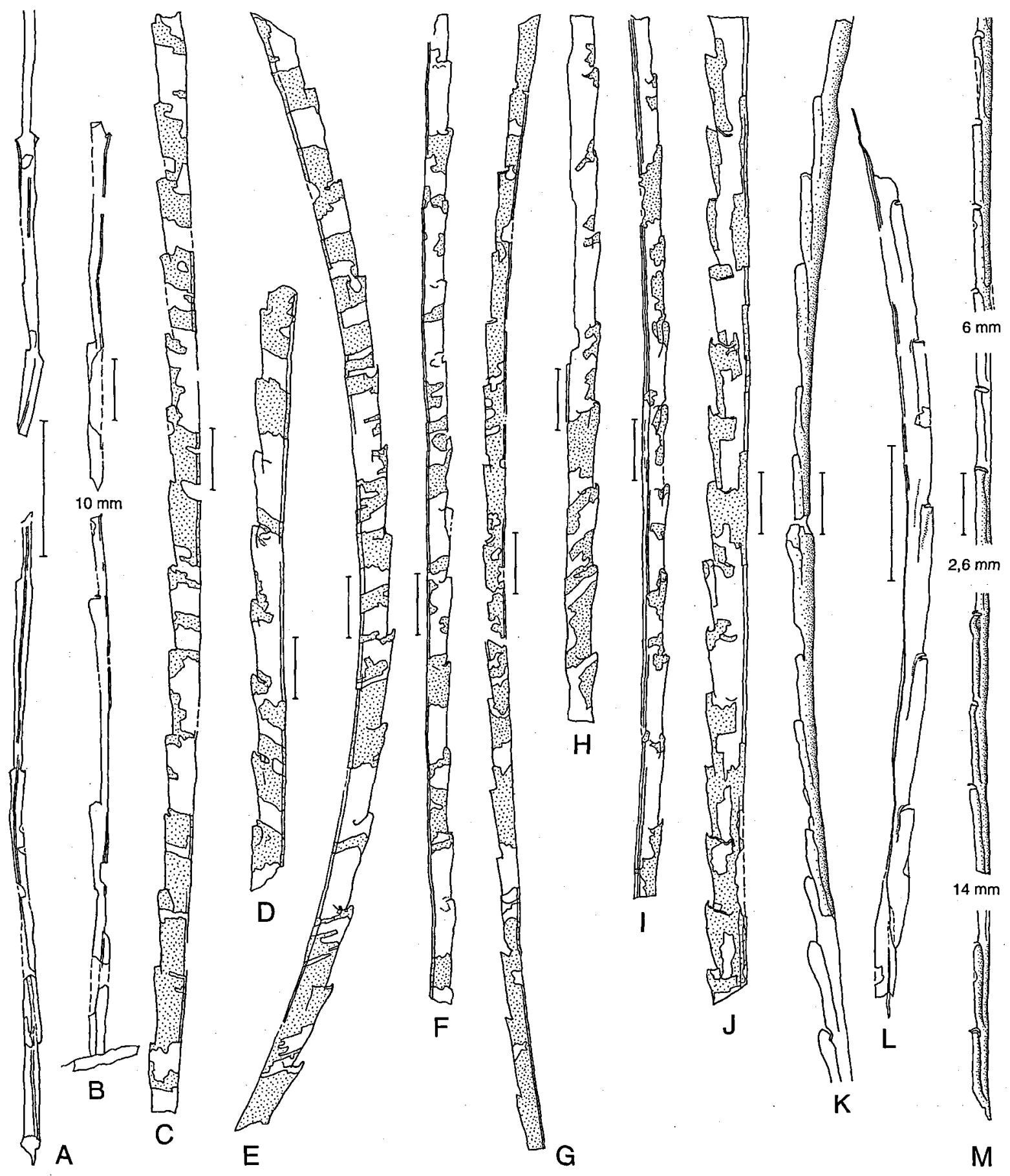

Fig. 22. A-G: Pribylograptus sandersoni (Lapworth, 1876), proximal fragments, vesiculosus Biozone, the southern Urals; A, MGUH 24330, exp. 671/8; B, MGUH 24331, exp. 671/8-288; C-J, mesial and distal fragments, vesiculosus Biozone, Billegrav-1 core; C, MGUH 24332, depth 14.05 m; D, MGUH 24333, 11.35-11.45 m; E, MGUH 24334, depth 11.35-11.45 m; F, MGUH 24335, depth 14.05 m; F, G, MGUH 24336, depth 14.05 m; H, MGUH 24337, depth 14.05 m; I, MGUH 24338, depth 14.00; J, MGUH 24339, depth $14.35 \mathrm{~m}$; K-M, ?Pribylograptus sp., vesiculosus Biozone; K, M, MGUH 24340, fragments of the same rhabdosome, Øle $\AA$, exp. 4; L, MGUH 24341, a proximal fragment, Kos-Istek region, exp. 1643/50-37. 
Sicula is about $1 \mathrm{~mm}$ long and $0.13 \mathrm{~mm}$ wide at the aperture. Its apex reaches the level of the half way of th1 length. Th1, $1 \mathrm{~mm}$ long, originates at the distance of $0.4 \mathrm{~mm}$ above the sicular aperture.

Remarks. - The specimens studied are preserved as fragments of different parts of rhabdosomes making a complete description of this species impossible. The longest fragment from Øle $\AA$ is strongly limonitized which results in incomplete preservation of the thecal apertures (Fig. 22K, M). This might be the reason for an almost undistinguishable thecal introversion. The well developed genicular rims and small slit-like apertural excavations give an impression that the specimen has huttagraptid affinities. The Uralian material is too fragmentary, although the extreme proximal end is quite well preserved (Fig. 22L). From Prb. sandersoni the present form differs in having much shorter sicula and less introverted thecae.

Genus Lagarograptus Obut \& Sobolevskaya 1968 in Obut et al. 1968.

Type species. - Lagarograptus inexpeditus Obut \& Sobolevskaya 1968 , by original designation.

Horizon. - Llandovery, vesiculosus to sedgwickii Biozones.

Diagnosis. - Rhabdosome with moderate dorsal curvature, relatively slim with tendency to be parallelsided. Sicula long, with metasicula occupying most of its length, apex reaching the level around the thl aperture and with high origin of th1 bud. Long slender thecae overlap about $1 / 2$ of their length; slit-like or semicircular apertural excavations and overhanging pronounced geniculum which may have well developed genicular flanges; a triangular shaped ventral apertural process is present in all thecae.

Remarks. - Lagarograptus was originally defined as a monospecific genus, based on Lg. inexpeditus, the type species from the lower triangulatus Biozone (Obut et al. 1968). Later, it was emended by Rickards (1976), who emphasized that the main diagnostic features of the genus are the parallel-sided rhabdosome,

Fig. 23. Lagaragraptus inexpeditus Obut \& Sobolevskaya, 1968, cyphus Biozone, Kos-Istek region, the southern Urals. A-E, fragments of the distal part of the rhabdosomes; A, MGUH 24342, exp. 399/4-30; B, MGUH 24343, sp. exp. 408-501; C, D, MGUH 24344, fragments of the same specimen, exp. 399-4-31; E, MGUH 24345, exp. 399-4-10, E1, E2, E3, details of thecal structure; F, MGUH 24345, a proximal part of a rhabdosome with sicula, same specimen as E; G, MGUH 24347, exp. 408-501a; H, MGUH 24347 , exp. 408-501a.

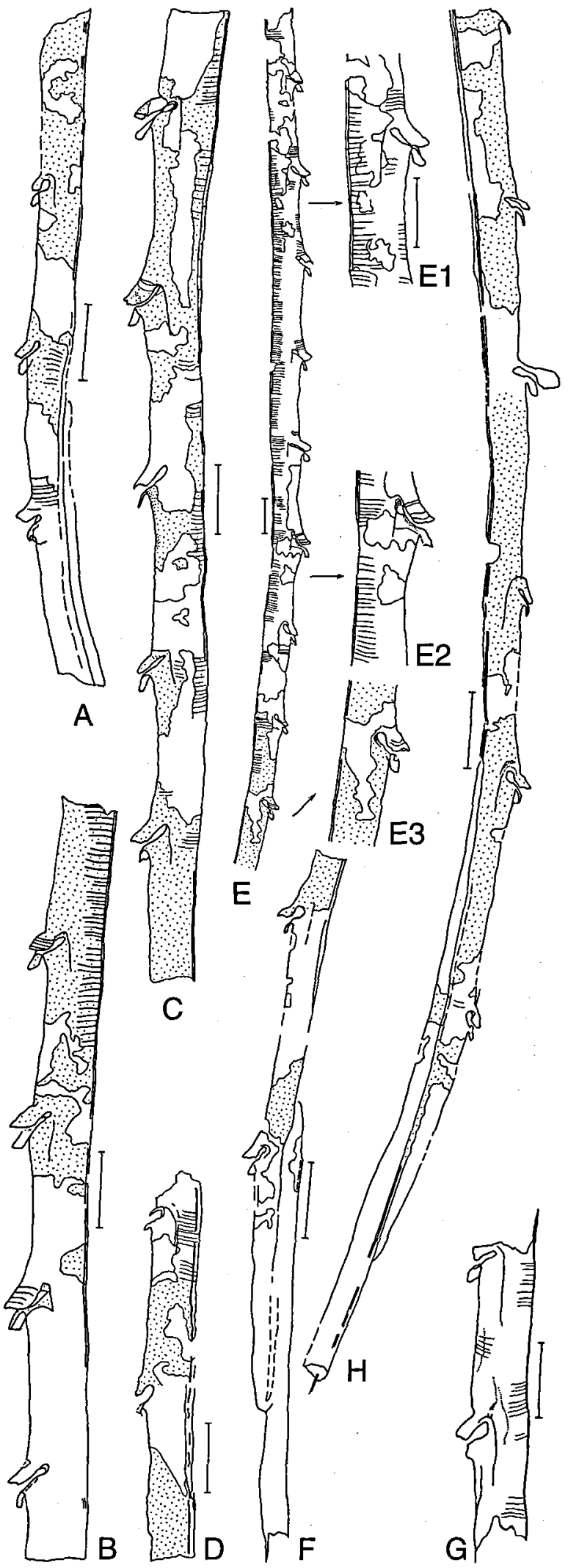




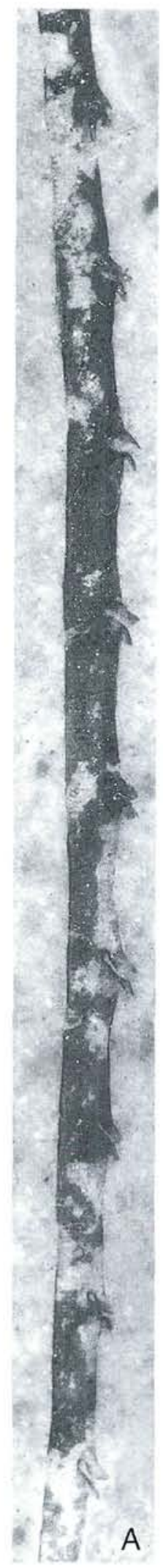

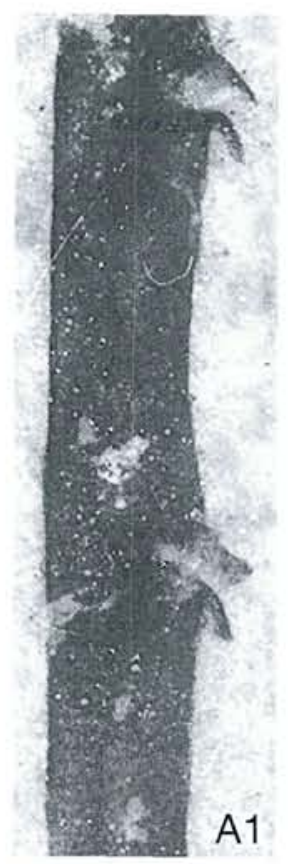

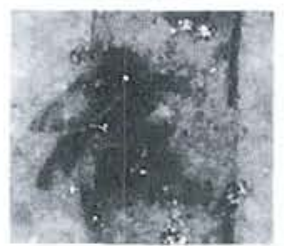

B1

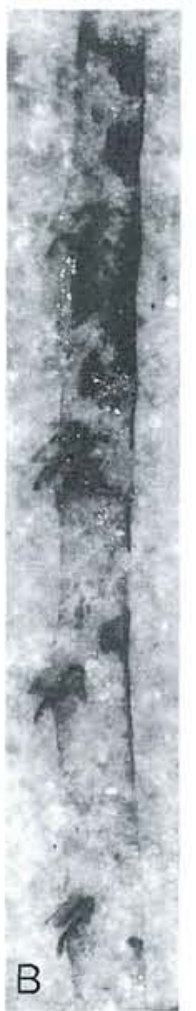

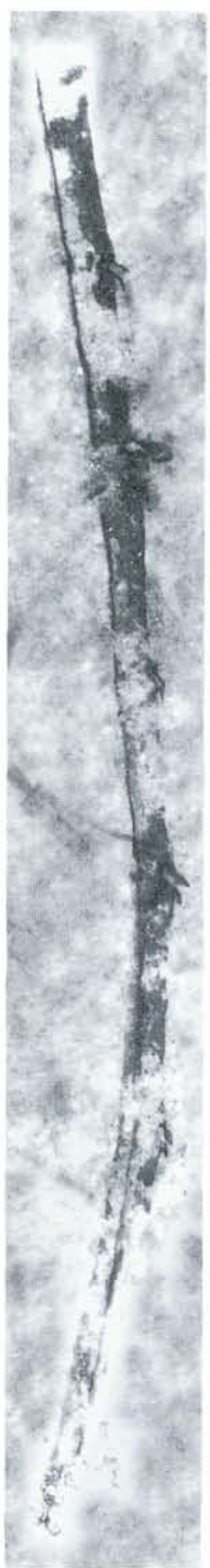

C
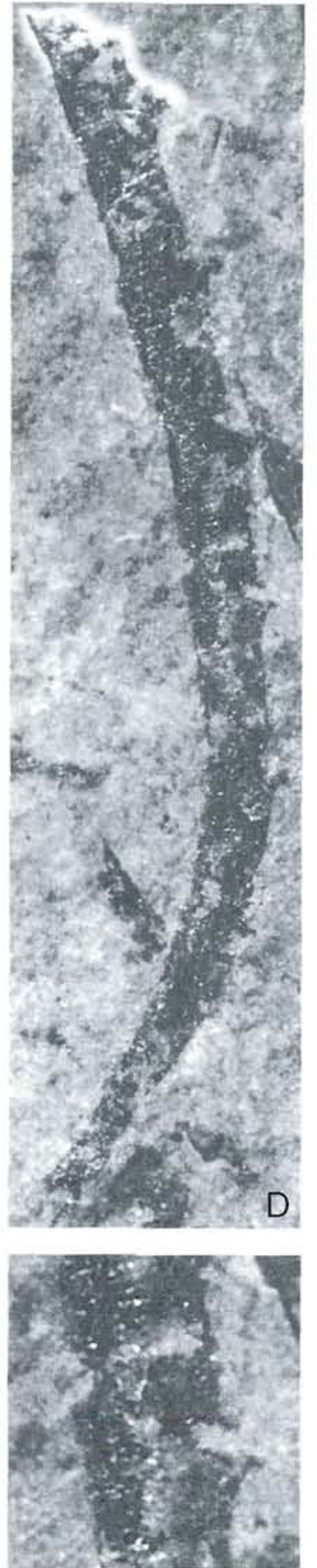

D1
Fig. 24. A-C:

Lagaragraptus

inexpeditus Obut \&

Sobolevskaya, 1968;

upper part of the

vesiculosus to cyphus

Biozone, exp. 399-4, the

Kos-Istek Region. A, B,

distal fragments, $\times 20 ; \mathrm{A} 1$,

$B 1$, enlarged parts of the

same rhabdosomes

showing thecal hoods and

ventral outgrowths; $\mathrm{A}$,

MGUH 24348; B, MGUH

24349, $\times 40 ;$ C, MGUH

24350 proximal part of the

rhabdosome with well

preserved long sicula, $x$

20; D, MGUH 24351,

Lagaragraptus karaensis

sp. nov., holotype, cyphus

Biozone, exp. 671/8,

Kara-Dzhilga, $\times 20 ;$ D1, a detail of the apertural part of a theca, showing hood and a small ventral

outgrowth, $\times 40$. 
the long sicula, the elongated and strongly overlapping thecae which may have genicular hoods and ventral apertural processes. In the emended generic diagnosis "Monograptus" tenuis Portlock was included in Lagarograptus because of the presence of the ventral apertural outgrowths (Hutt 1968) which resemble those of Lg. inexpeditus.

Significantly shorter ventral structures have been discovered in Lagarograptus karaensis sp. nov. from the cyphus Biozone of the southern Urals but, contrary to $L g$. inexpeditus and $L g$. tenuis, $L g$. karaensis posesses a much shorter sicula and it does not show the thecal elongation. At the same time some species described from the convolutus Biozone of Bohemia (Štorch 1988) have been assigned to Lagarograptus, though all of them lack both the ventral apertural processes and genicular hoods. This somewhat arbitrary assignment was mainly based on their shared general common features such as dorsally curved rhabdosome, long sicula, geniculate thecae with slightly expanded and everted aperture. Several taxa possessing ventral apertural processes are with reservations assigned to the genus Lagarograptus. More studies are needed to elucidate the taxonomic value of the ventral apertural processes, as their appearance in different lineages cannot be excluded. Variation both of sicula size, and in the degree of thecal elongation in different species possessing genicular flanges and ventral processes, are additional characters that have to be evaluated for better understanding of their evolutionary relationships.

Lagarograptus inexpeditus Obut \& Sobolevskaya 1968 in Obut et al. 1968

Figs $23 ; 24 \mathrm{~A}-\mathrm{C}$

1968 Lagarograptus inexpeditus sp. nov.; Obut et al., p. 91-92, pl. 18, figs 4-6; pl. 19, figs 1-6.

Type. - Holotype figured Obut et al. 1968, pl. 18, fig. 4, CGM 14/976, lower triangulatus Biozone, Norilsk region, IM24, depth 316,4-320.4 m, North Siberia.

Material. - 10 fragmentary, but well preserved specimens showing different parts of rhabdosomes, including extreme proximal ends. The fusellar structure is well seen due to a special kind of preservation with not strongly carbonized periderm in the weathered silicious rocks. Exp. 399-4, upper combined vesiculo-

Fig. 25. A, C, D, Huttagraptus ninae sp. nov., combined vesiculosus-cyphus Biozone; A, MGUH 24352, exp. 19091; Kos-Istek region; B, Lagaragraptus karaensis MGUH 24351, holotype, exp. 671/8-267, Kara-Dzhilga; C, holotype, MGUH 24353; D, MGUH 24354, exp. 671/811a, Kara-Dzhilga; E, Huttagraptus sp. 3, MGUH 24355 , $\emptyset$ Øle $\AA$, exp. 4a, vesiculosus Biozone.

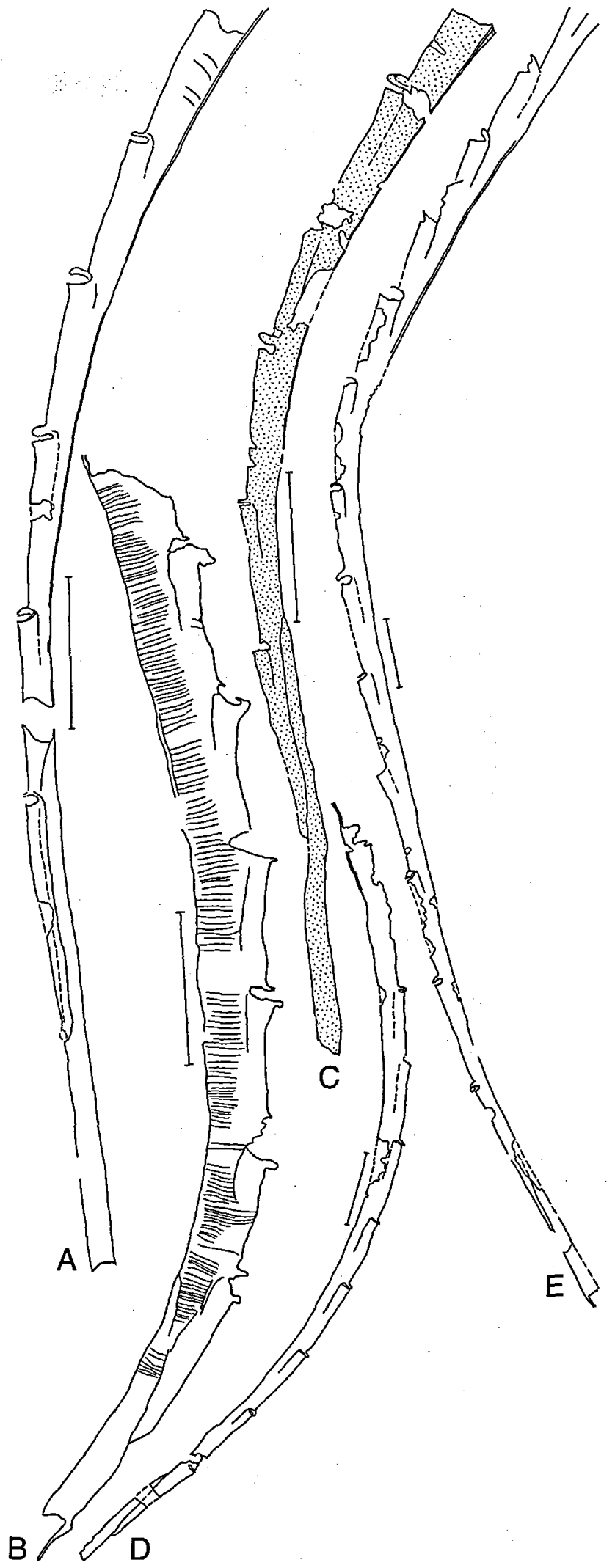




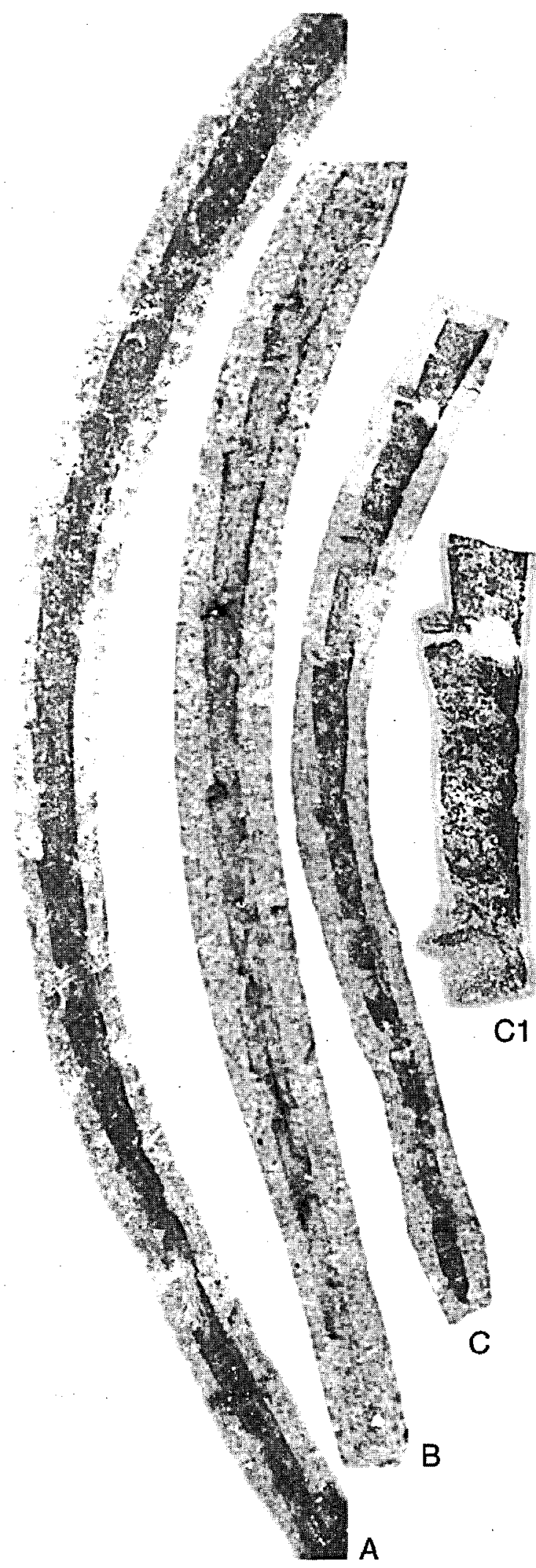

sus-cyphus Biozone, Kos-Istek region, the southern Urals.

Description. - The gently dorsally curved rhabdosome is more than $15 \mathrm{~mm}$ long with an open dorsal curvature. The dorso-ventral width increases from 0.35$0.4 \mathrm{~mm}$ at th 1 to the maximum of $0.5-0.55 \mathrm{~mm}$ within the first $10 \mathrm{~mm}$.

Uniform thecae possess a strong geniculum and shovel-like genicular hoods overhanging the whole aperture. The hoods are $0.25 \mathrm{~mm}$ long and $0.15 \mathrm{~mm}$ wide at their margins. The present material clearly displays the irregular microfusellar structure of the hood. The supragenicular walls are straight or slightly concave and parallel to the rhabdosome axis throughout the rhabdosome, except at the extreme proximal end where thecae are inclined at $5^{\circ}$. The apertures are straight and strongly everted. Triangular ventral processes grow outwards from the ventral margin of the thecal apertures. Initially narrow they become rapidly transversally expanded. There is a suggestion of their convex shape. They are $0.16 \mathrm{~mm}$ long and $0.10 \mathrm{~mm}$ wide at the margin. Interthecal septa are indistinct, although they appear to overlap slightly more than at $1 / 3$ of their length in the distal part of the rhabdosome. Thecae number 8 in $10 \mathrm{~mm}$.

The slightly dorsally curved sicula, is more than 4.00 $\mathrm{mm}$ long and $0.2 \mathrm{~mm}$ wide in the aperture, with a very narrow apical part and an apex reaching the level above the th 2 aperture. Th1 originates at a distance of 0.8 $\mathrm{mm}$ from the base of sicula. Initially it grows shortly in a horizontal direction (Fig. 23F), further on, after a sharp knee-like bend it grows upwards parallel to the sicula at a distance of $1.8-1.9 \mathrm{~mm}$.

Remarks. - The present specimens agree well with the original description of $L g$. inexpeditus (Obut et al. 1968). The slightly lower position of the sicular apex and higher origination of th 1 in the Uralian form $(0.75$ $0.8 \mathrm{~mm}$ as compared with $0.4-0.5 \mathrm{~mm}$ in the Siberian specimens) are the only differences. $L g$. inexpeditus is similar to $L g$. tenuis (Portlock), known from the sedgwickii Biozone, in shape of thecae having ventral processes at their apertures. The absence of dorsal hoods in $\mathrm{Lg}$. tenuis, so well developed in Lg. inexpeditus is an important difference between two species. Lg. inexpeditus has as well slightly shorter sicula, the wider extreme proximal end and its maximum dorsoventral width does not exceed $0.55 \mathrm{~mm}$.

Fig. 26. A-C, Huttagraptus ninae sp. nov., vesiculosus to cyphus Biozones, southern Urals; A, MGUH 24357; C, MGUH 24353; C1, details of apertural structure of thecae; exp. 671/8, Kara-Dzhilga; B, MGUH 24353, holotype, exp. 1909, Kos-Istek region. A-C, × 20; C1, × 40. 
Lagarograptus karaensis sp. nov.

Figs 24A-C; 25B

Type. - Holotype, Figs 24D, 25B, MGUH 24351 (Specimen 267), exp. 671/8, the Kara-Dzhilga, cyphus Biozone, the southern Urals, Kazakhstan.

Derivation of name. - From the geographical name Kara-Dzhilga Valley.

Material. - One well preserved specimen.

Description. - The rhabdosome is slightly dorsally curved, $10 \mathrm{~mm}$ long, widening rapidly within the first $10 \mathrm{~mm}$. The dorso-ventral width is $0.48 \mathrm{~mm}$ at th 1 and th $2,0.6 \mathrm{~mm}$ at th5 and the maximum of $0.65 \mathrm{~mm}$ is attained at th15.

The geniculate thecae have short genicular hoods $(0.1 \mathrm{~mm})$ and ventral processes $(0.1 \mathrm{~mm})$. Slightly concave free ventral walls are inclined at about $5^{\circ}$ to the rhabdosome axis. Thecae overlap more than $1 / 3$ of their length and number about 8 in $10 \mathrm{~mm}$.

The sicula is $1.9 \mathrm{~mm}$ long and $0.2 \mathrm{~mm}$ wide at the aperture. Th1, $1.6 \mathrm{~mm}$ long, originates at the level about half-way of the sicula length. The sicular apex reaches the th1 aperture.

Remarks. - The present species differs from Lg. inexpeditus and $L g$. tenuis in having significantly shorter sicula and less developed ventral apertural processes. From the former species Lg. karaensis can be as well distinguished by the much less developed genicular hoods and more inclined free ventral walls of thecae.

\section{Morphology and phylogeny}

Rickards and Hutt (1970) postulated the origin of the first monograptid species, Atavograptus ceryx (in the persculptus Biozone) from glyptograptid stock. Recently, the idea of the akidograptid origin for the first monograptid colony was forwarded by $\mathrm{Li}$ (1990) and supported by Melchin (pers. comm. 1996). This new suggestion is based on the much closer similarity between akidograptids and Atavograptus ceryx in having early upward growth of the first theca and late differentiation of th $1^{2}$. Therefore, the transition from akidograptid to monograptid requires a less radical transformation of the early astogeny than a direct evolution from a glyptograptid or normalograptid.

The earliest monograptids studied from the ascensus, acuminatus and vesiculosus biozones share extremely long and slender rhabdosomes. The growth of the colonies continued beyond the average length of contemporaneous biserial graptolites and their length is similar to that of the late Ordovician nemagraptids.
The long slender rhabdosomes typical for these early monograptids partly explain the rarity of the extreme proximal end fragments. At an early stage in their evolution, however, monograptids with different thecal morphology were able to regenerate their rhabdosomes after breakage. Occurrences of bipolar uniserial rhabdosomes in the vesiculosus Biozone have been recorded by Rickards (1973). In the material studied here several well preserved specimens of "Pristiograptus" pristinus show a regenerating branch (Fig. 19).

Variable dorsal curvature, expressed mostly in the proximal part of the rhabdosome was typical for the majority of earliest monograptid species. By the end of the vesiculosus Biozone and beginning of the cyphus Biozone the dorsal curvature became more rigid (Coronograptus, Lagarograptus). This feature was shared also by the contemporaneous dimorphograptids with a long uniserial proximal part. The numerous specimens from the Billegrav-1 core, depth 18.15$16.75 \mathrm{~m}$, show striking similarity between monograptids, assigned to Huttagraptus sp. 1 and uniserial parts of $D i$. elongatus. They closely resemble each other in having dorsally curved rhabdosomes, and similar thecal size and geniculation, making it difficult to distinguish between them (Fig. 17). Among the observed differences only less strong rhabdosomal curvature and slightly more rapid increase in the dorsoventral width in the uniserial portion of Di. elongatus can be mentioned.

In general, the taxonomic differentiation of the early Llandovery monograptids at generic and species level is based on three main morphological criteria as far as theca and proximal end structure are concerned.

The first is the degree of thecal geniculation, resulting in the glyptograptid or "monoclimacid" thecae. This feature is used to differentiate two genera, e.g. Atavograptus Rickards and Huttagraptus gen. nov.

Simple, weakly geniculated thecae with horizontal or slightly everted, undifferentiated apertures are common for Atavograptus. This feature, combined with the short sicula, was retained from the assumed biserial ancestral stock. The first monograptids, e.g. A. ceryx and $A$. primitivus represent the generalized or standard Atavograptus morphotype, which did not undergo noticeable changes during ascensus-acuminatus time. Recent data (Li 1983; Lukasik \& Melchin 1994) and the present material show that the Atavograptus line consists of three successive chronological species such as At. ceryx (in the persculptus Biozone), At. primitivus (in the ascensus-acuminatus Biozone) and At. atavus (in the vesiculosus-gregarius biozones), which share the same shape of thecae. The elongation of sicula and thecae with no increasing thecal overlap are the only changes which could have easily bridged the transition between At. atavus and At. primitivus (Fig. 27). Further morphological changes within the Atavograptus line, expressed in $A$. atavus are an increase in length and dorso-ventral width of the colony, attennuation 


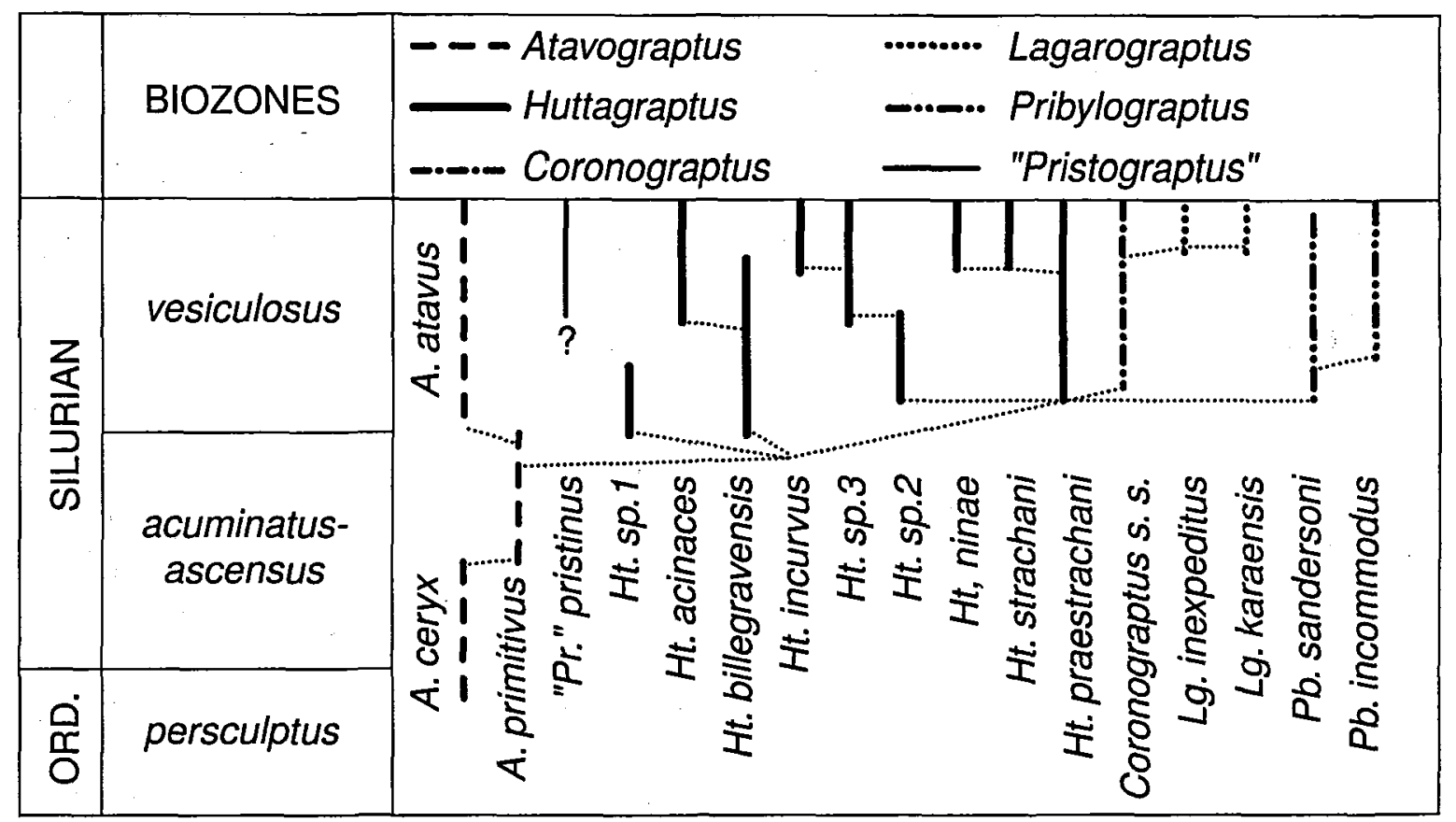

Table 4. Suggested phylogenetic relationships of the species described.

of the extreme proximal part and elongation of thecae resulting in more widely spaced thecae.

The Atavograptus stem line continued as a conservative group and at the same time it could have played an important role in the monograptid diversification, first in the vesiculosus Biozone and later, during Aeronian-early Telychian time. For example it could have been the source of lineages with simple thecal morphology, as seen in "Pristiograptus" pristinus. The further development of this species towards early Aeronian robust Pristiograptus s.s. (Pr. concinnus) seems likely (Rickards et al. 1977, Fig. 30). The evolutionary potential of Atavograptus as the source of new progressive lineages can be compared with the standard morphotypes presented by the Normalograptus group among contemporaneous biserial graptolites (Koren' \& Rickards 1996) and with the Pristiograptus dubius stock during the Late Wenlock recovery from the lundgreni extinction event (Koren' \& Urbanek 1994).

Strongly geniculate weakly hooded thecae are typical for Huttagraptus gen. nov., Pribylograptus and Lagarograptus. This character is first seen in Hutta. graptus sp. $1, \mathrm{Ht}$. billegravensis sp. nov. and $\mathrm{Ht}$. praestrachani which derive from At. pristinus at the beginning of the vesiculosus Biozone. Geniculate thecae are retained in pribylograptids and in lagarograptids which evolve most probably from $\mathrm{Ht}$. praestrachani during vesiculosus time (Fig. 27).

The second important diagnostic feature of the vesiculosus Biozone monograptids is the presence of variable genicular rims, flanges or hoods, ventral apertural processes and/or lateral apertural expansions. A differentiation of the genera Huttagraptus gen. nov., Pribylograptus and Lagarograptus are based on different combinations of these features. Strongly geniculate thecae with genicular flanges and hoods place huttagraptids morphologically apart from the Atavograptus stock. The various size and astogenetic penetrance of these structures are used for the species differentiation in Huttagraptus gen. nov. The specialized Pribylograptus morphotype appears close to the beginning of the vesiculosus Biozone (Fig. 27). Together with genicular flanges it possesses characteristic lateral apertural expansions which, in flattened material, give an impression of the introverted appearance of the thecal aperture. The long slender rhabdosome lacks any elongation of thecae and proximal end. Based on the present material, it is suggested that $H t$. praestrachani is the probable ancestor of the first pribylograptids (Fig. 27).

The new Lagarograptus morphotype posesses the peculiar ventral apertural outgrowths and, at the same time it retains the main huttagraptid features such as a long sicula and strongly geniculated thecae with more elaborated genicular hoods. This can be taken as an example of the extreme morphological specialization. Lagarograptus could have derived from Huttagraptus stem via early coronograptids, which first show a tendency to flaring thecal aperture (Fig. 27).

The proximal end structure of the early monograptids, e.g. the size and proportions of the sicula, posi- 
tion of the origin of th1, length and overlap of the proximal thecae is the third key morphological feature critical for species differentiation in Atavograptus, Huttagraptus and Lagarograptus.

The elongation of the sicula and extreme proximal end also the high position of the origin of th1 are first seen in some biserial (Akidograptus and Parakidograptus) and uniserial graptolites (At. primitivus) in the ascensus and acuminatus biozones. Since the beginning of the vesiculosus Biozone this is shared by some early huttagraptids, e.g. Ht. billegravensis and Huttagraptus sp. 2 and dimorphograptids with a long uniserial part. An extreme value of the sicular length and the high position for the th1 bud is reached in Ht. acinaces in late vesiculosus time (Fig. 27). This character is interpreted here as an important morphological novelty introduced independently in several lineages first in the ascensus and acuminatus biozones, then in the vesiculosus Biozone.

The other important feature with respect to taxonomy is the proportions of prothecal and metathecal parts, expressed in thecal elongation and degree of their overlap. They are well represented in different lineages as it is seen in Ht. acinaces (Figs 11,12) and "Pr." pristinus (Fig.19). The former displays an extreme and progressive elongation of metathecae during astogeny, whereas in the latter species thecae consist mostly of the prothecal part and do not show any noticable increase in overlap during astogeny.

A number of morphological characters such as inclination of thecae to the rhabdosome axis, thecal overlap, degree of geniculation, presence or absence of genicular hoods are subject to astogenetic variation. Most of the species studied are characterized by gradual modification of successive thecae in the colony (Lagarograptus, Pribylograptus). Huttagraptids, in particular, such as Ht. billegravensis sp. nov., $H t$. praestrachani and Huttagraptus sp. 2 show well pronounced thecal biformity beginning in the lower vesiculosus Biozone. Their proximal and mesial thecae are distinctly geniculated, while those in the distal part have almost straight free ventral walls, even allowing for the effects of preservation. In some cases, however, e.g. $H$. strachani the monoclimacid thecae are spread almost through the whole colony.

The overall pattern of the vesiculosus Biozone diversification among monograptids is marked by the appearance of several kinds of derived thecal structures based on the Atavograptus stem line. Some of them were succeptible to further progressive changes (Rickards et al. 1977). However, the unsatisfactory preservation of present material and incompleteness of data on stratigraphical ranges of particular species makes the reconstruction of the individual lineages difficult.

\section{Acknowledgments}

The project was supported by a grant from the Carlsberg Foundation, which made it possible for T.N. Koren' to stay in Copenhagen for graptolite studies. Technical facilities were kindly provided by the Geological Museum and Geological institute of the University of Copenhagen. One of the authors (TNK) recieved a financial support from the Russian Foundation for fundamental science (Grant N 96-65-758). The authors are greatly indepted to Dr. G. Pedersen, for the access to the Bille-grav-1 core material and for permission to carry out a detailed graptolite sampling, as well as to J. Holle for a substantial help in collecting graptolites on Bornholm. Many thanks are due to Prof. R. Cooper for critical remarks and improvement of the English text and to Dr. A. T. Nielsen for fruitful discussion while preparing the draft of the paper. The paper was substantially improved resulting from critical comments and suggestions made by Drs. J. Hutt and M. J. Melchin, who refereed the manuscript.

The illustrations were prepared with the help of $T$. Bredsdorff (Geological Museum of the University of Copenhagen). The X-Ray photographs were done by J. Aagaard in the Geological Institute of the University of Copenhagen. The light photography of the graptolites was undertaken by B. S. Pogrebov in the Department of Palaeontology of the University of St. Petersburg and by S. L. Jakobsen in the Geological Museum of the University of Copenhagen. A. K. Brantsen helped correcting the manuscript. The authors direct their thanks to the above mentioned persons.

\section{Dansk sammendrag}

Der er foretaget unders $\varnothing$ gelser af monograptider (enkeltradede graptoloider) i den komplette lagserie af nedre Llandovery graptolitskifre fra Billegrav-1 boringen ved $\varnothing$ le $\AA$ på Sydbornholm. De taxonomiske studier er især koncentreret omkring monograptidfaunaen i vesiculosus Biozonen i de nærliggende blottede lag i Øle $\AA$. Yderligere er der til sammenligning undersøgt monograptider fra en kondenseret serie af dybbassin-aflejringer bestående af carbonatholdige skifre fra vesiculosus Biozonen i Sakmara Formationen i Syd Ural. Aflejringsmiljøerne og biostratigrafien $i$ de to områder er kort beskrevet, og der er foretaget en sammenligning af de to faunaer, som tilsammen kan henføres til 5 slægter og 17 arter, hvoraf 4 er nye og 4 er i åben nomenklatur. Der er beskrevet en ny slægt Huttagraptus med typeart Ht. praestrachani.

På grundlag af de taxonomiske studier af monograptider er phylogenien og diversitetsdynamikken diskuteret. 


\section{References}

Bjerreskov, M. 1975: Llandoverian and Wenlockian graptolites from Bornholm. Fossils and Strata 8, 1-94.

Bjerreskov, M. 1991: Pyrite in Silurian graptolites from Bornholm, Denmark. Lethaia 24, 351-361.

Bjerreskov, M. \& Stouge, S. 1985: Field excursion guide Bornholm, Denmark. Graptolite Working Group of the International Palaeontological Association Third International Conference. Copenhagen, Denmark, Institute of Historical Geology and Palaeontology, University of Copenhagen. $23 \mathrm{pp}$.

Bulman, O. M. B. 1970: Graptolithina, with sections on Enteropneusta and Pterobranchia. In Teichert, C. (ed.) Treatise on Invertebrate Paleontology, V. 2nd edition. xxxii, $163 \mathrm{pp}$.

Chen Xu 1984: Silurian graptolites from southern Shaanxi and northern Sichuan with special reference to classification of Monograptidae. Palaeontologica Sinica 166 B, $20,102 \mathrm{pp}$.

Chen Xu 1986: Early Silurian isolated graptolites from Yichang in W. Hubei, China. Acta Palaeontologica Sinica 25, 229-238.

Chen Xu \& Lin Yao-kun 1978: Lower Silurian graptolites from Tongzi, northern Guizhou. Memoirs of the Nanjing Institute of Geology and Palaeontology, Academia Sinica $12,1-76$.

Elles, G. L. \& Wood, E. M. R. 1911-1918: A monograph of British Graptolites, Palaeontographical Society (Monograph), 359-539.

EUGENO-S Working Group 1988: Crustal structure and tectonic transition between the Baltic Schield and the North German Caledonides (the EUGENO'S Project). In Freeman, R, Berthelsen, A. \& Müller, S. (eds) The European Geotraverse Part 4. Tectonophysics 150, 253348.

Fang Yi-ting, Liang Shi-jing, Zhang Da-liang \& Yu Jinlong 1990: Stratigraphy and graptolite fauna of Lishuwo Formation from Wuning, Jiangxi. Nanjing University Publishing House, Nanjing, (in Chinese with English summary), $155 \mathrm{pp}$.

Hutt, J. E. 1968: A redescription of the Llandoverian monograptid "Graptolithus" tenuis Portlock, 1843. Geological Magazine 105, 251-255.

Hutt, J. E. 1974: A new group of Llandovery biform monograptids. Special Papers in Palaeontology 13, 189203.

Hutt, J. E. 1974-75: The Llandovery graptolites of the English Lake District. Palaeontographical Society Monographs 1-2, $137 \mathrm{pp}$.

Hutt, J. E. \& Rickards, R. B. 1970: The evolution of the Earliest Llandovery monograptids. Geological Magazine $107,67-77$.

Hutt, J. E., Rickards, R. B. \& Skevington, D. 1970: Isolated Silurian graptolites from the Bollerup and Klubbudden stages of Dalarna, Sweden. Geologica et Palaeontologica 4, 1-23.

Jaanusson, V. 1973: Morphological Discontinuites in the Evolution of Graptolite Colonies. In Broardman, R. S., Cheetham, H. A. \& Oliver, W. A., Jr. (eds) Animal colonies Development and Function Through Time, 515-521.

Jaekel, O. 1889: Über das Alter des sogenannten Graptolithengesteins. Zeitschrift deutsche geologisches Gesell- schaft 41, 653-90.

Jones, O. T. 1909: The Hartfell-Valentian Succession in the District around Plynlimon and Pont Erwyd (North Cardiganshire). Quarterly Journal of the Geological Society of London $65,463-537$.

Koren', T. N. 1964: Silurian graptolites in Urals and their stratigraphic bearing. Autoreferat dissertaziina soiskanie zvanija kandidata geologo-mineralogicheskikh nauk, Leningrad, VSEGEI, 23 pp (In Russian).

Koren', T. N. 1967: Some Llandovery graptolites in the Urals. Trudy VSEGEI, Novaya Seria 129, 189-197. (In Russian).

Koren', T. N. 1986: Silurian zonal stratigraphy and system boundaries based on graptolites. Autoreferat dissertaziina soiskanie zvania doctora geologo-mineneralogicheskikh nauk, Leningrad VSEGEI, 42 pp. (in Russian).

Koren', T. N. \& Rickards, R. B. 1996: Taxonomy and evolution of Llandovery biserial graptoloids from the southern Urals, western Kazakhstan. Special Papers in Palaeontology 54, $103 \mathrm{pp}$.

Koren', T. N. \& Urbanek, A. 1994. Adaptive radiation of monograptids after the late Wenlock crisis. Acta Palaeontologica Polonica 39, 137-167.

Lapworth, C., 1873: On an improved classification of the Rhabdophora. Geological Magazine 1, 10, 500-4, 55560.

Lapworth, C., 1876: On Scottish Monograptidae, Geological Magazine 2, 3, 308-21, 350-60, 499-507, 544-52, pl. 10-13, 20.

Leonenok, N. I., 1955: Silurian deposits in the Kos-Istek Region (Northern Mugodzhary). Laboratorii geologii uglia ANSSSR Vyp. III 116-225.

Li Ji-jin 1983: Graptolithina. In Palaeontological Atlas of East China (1). Volume of Early Paleozoic, Chiefly edited by Nanjing Institute of Geology and Mineral Resources. Geological Publishing House, Beijing, China, 493-396 (In Chinese).

$\mathrm{Li} \mathrm{Ji-jin} \mathrm{1987:} \mathrm{On} \mathrm{the} \mathrm{origin} \mathrm{of} \mathrm{dimorphograptids.} \mathrm{Bulletin}$ of the Geological Society of Denmark 35, 171-177.

Li Ji-jin, 1990: Discovery of monograptids in the basal part of Lower Silurian from S. Anhui with special reference to their origin. Acta Palaeontologica Sinica 29, 204-215.

Lindström, M. 1971: Vom Anfang, Hochstand und Ende eines Epikontinentalmeeres. Geologische Rundschau 60, 414-438.

Lukasik, J. J. \& Melchin M. J. 1994: Atavograptus primitivus (Li) from the earliest Silurian of Arctic Canada: implications for monograptid evolution. Journal of Paleontology 68, 1159-1163.

Melchin, M. J. 1989: Llandovery graptolite biostratigraphy and paleobiogeography, Cape Phillips Formation, Canadian Arctic Islands. Canadian Journal of Earth Sciences 26, 1726-1746.

Melchin, M. J. in press: Morphology and phylogenetic classification of some Early Silurian diplograptid genera from Conwallis Island, Arctic Canada. Palaeontology.

Mitchell, C. E. 1987: Evolution and phylogenetic classification of the Diplograptacea. Palaeontology 30, 353405.

Obut, A. M. \& Sobolevskaya, R. F. 1966: Lower Silurian graptolites in Kazakhstan. Akademia Nauk SSSR, Sibirskoe Otdelenie, Instituta Geologii i Geofiziki Ministertvo Geologii SSSR Nauchno-Issledovatel'skij Instituta Geologii Arktiki. 56 pp. (In Russian).

Obut, A. M., Sobolevskaya, R. F. \& Merkurjeva, A. P. 1968: 
Graptolity landoveri v kernakh burovykh skvazhin Norylskogo rayona: Akadademya Nauk SSSR. Sibirskoe Otdelenie, Instituta Geologii I Geofiziki; 1-126 (In Russian).

Pedersen, G. 1988: The sedimentology of Lower Palaeozoic black shales from the shallow wells Skelbro 1 and Billegrav 1, Bornholm. Bulletin of the Geological Society of Denmark 37, 151-173.

Přibyl, A. 1948: Bibliographic index of Bohemian Silurian graptolites. Knihovna statniho geologickeho Ústavu ceskoslovenske Republiky 22, 1-96.

Přibyl, A. \& Spasov, C. 1955: Bibliographic index of Bulgarian Upper Silurian graptolites, Izvistiya Na Geologicheskiya Institut (Strashimir Dimitrov) 3, 163-209.

Rickards, R. B. 1970: The Llandovery (Silurian) graptolites of the Howgill Fells, Northern England. Palaeontographical Society (Monograph), $108 \mathrm{pp}$.

Rickards, R. B. 1973: Bipolar monograptids and the Silurian genus Diversograptus Manck. Paläontologisches Zeitschrift 47, 175-187.

Rickards, R. B. 1974: A new monograptid genus and the origin of the main monograptid genera. Palaeontological Association London, Special Papers in Palaeontology $13,141-147$.

Rickards, R. B. 1976: Classification of Monograptus: A redefinition of some Llandovery graptolite genera. Academy of Science Estonian SSR, Institute of Geology, 155163.

Rickards, R. B. \& Hutt, J. E. 1970: The earliest monograptid. Proceedings of the Geological Society of London $1663,115-119$.

Rickards, R. B., Hutt, J. E. \& Berry, W. B. N. 1977: Evolution of the Silurian and Devonian graptoloids. Bulletin of the British Museum (Natural History) Geology 28, 1, $120 \mathrm{pp}$.

Rickards, R. B. \& Koren', T. N., 1974: Virgella meshworks and sicular spinosity in Llandovery graptoloids. Geological Magazine 111, 241-255.

Rickards, R. B. \& Rushton, A. W. A. 1968: The thecal form of some slender Llandovery Monograptus. Geological Magazine 105, 264-274.

Rigby, S. 1991: Feeding strategies in graptoloids. Palaeontology 34, 797-813.

Ruzhentsev, S. V. \& Samygyn, S. F. 1969: Tectonic evolution of the South Uralian ophiolites. In Malpas, Y. \& Talkinton, R. W. (eds.) Ophiolites of the Canadian Appalachians and Soviet Urals, 115-161. Department of Geology Memorial University of Newfoundland, Geology Report no. 8 St. John's. Contributions to International Geological Correlation Programme Project 39 Ophiolites.

Sengör, A. M. C., Natalí, B. A. \& Burtman, V. S. 1993: Evolution of the Altaid tectonic collage and Palaeozoic crustal growth in Eurasia. Nature 364, 6435, 299-307.

Storch, P. 1986: Ordovician-Silurian boundary in the Prague Basin (Barrandian area, Bohemia). Sbornik Geologickych Věd Geologie 41, 69-103.

Štorch, P. 1988: Earliest Monograptidae (Graptolithina) in the lower Llandovery sequence of the Prague Basin (Bohemia). Sbornik Geologikych Věd Paleontologie 29, 948.

Storch, P. 1994: Graptolite biostratigraphy of the Lower Silurian (Llandovery and Wenlock) of Bohemia. Geological Journal 29, 137-165.
Törnquist, S. L. 1899: Researches into Monograptidae of the Scanian Rastrites Beds. Lunds Universitets Årsskrift $35,1-25$.

Urbanek, A. 1963: On generation and regeneration of cladia in some Upper Silurian monograptids. Palaeontologica Polonica 8, 127-234.

Urbanek, A. 1973: Organization and Evolution in Graptolites. In Boardman, R. S., Cheetham, A. H. \& Oliver, W. A. Jr. (eds) Animal colonies Development and Function Through Time. Dowden, Huchinson \& Ross Inc., 441514.

Urbanek, A., Koren', T. N. \& Mierzejewski, P. 1982. The fine structure of the virgular apparatus in Cystograptus vesiculosus. Lethaia 15, 207-228.

Vejbæk, O. V., Stouge, S. \& Poulsen K. D., 1994: Palaezoic tectonic and sedimentary evolution and hydrocarbon prospectivity in the Bornholm area. Ministry of environment and Energy, DGU Series A 34, 23 pp., Geological Survey of Denmark.

Yang Da-quan, Ni Yu-Nan, Li Ji-Jin, Chen Xu, Lin YaoKun, Yu Jian-Hua, Jiao Shi-ding, Fang Yi-ting, Ge MeiYu \& Mu En-Zhi 1983: Graptolithina, 353-508. In Nanjin Institute of Geology and Mineral Resources, Palaeontology Atlas of East China Area (Part 1), Early Palaeozoic Volume. Geological Publishing House, Beijing.

Ye Shao-hua 1994: New material of the earliest monograptids from Sichuan, SW China. In Chen Xu, Erdmann, B.-D. \& Ni Yu-nan (eds) Graptolite Research Today, 249-255. Nanjing University Press.

Zonenshein, L. P., Kuzmin, M. I. \& Natapov, L. M. 1990: Geology of the USSR: A Plate Tectonic Synthesis, Geodynamic Series 21, American Geophysical Union 1990, $242 \mathrm{pp}$. 